

\title{
INSECTS OF THE NORTHERN PARTS OF BRITISH AMERICA.
}

\author{
COMPILED BY THE REY. C. J. S. BETHITNE.
}

Editor of the "Canadian Entomoloyist."

From " Firby's Fauna Boreali-Americana: Insecta."

\section{I.-COLEOPTERA.}

For ten years we have been try $\mathrm{g}$, and trying in vain, both in England and America, to obtain a copy of Kirby's descriptions of the insects of the Northern parts of British America, contained in the fourth volume of Riciardson's Fauna Boreali-Americana, published at Norwich in 1837: Many of our friends have been making similar attempts, and always with the like illsuccess. We have had, howerer, occasional access to a copy in the library of the University of Toronto, which, with the exception of one in the library of Parliament at Ottawa, is the only copy we know of in Canada. By the kindness of Prof. Croft we have obtained a loan of the copy belonging to the University, and, with the full approbation of nany of our friends and correspondents, we now propose re-publishing from it in the pages of the Canadian Entomologist, Kirby's descriptions of new species and such other matter as may be deemed of special value or interest. As the work consists of upwards of 300 quarto, pages, it will be necessary for us to omit almost everything except the descriptions of species that cannot be obtained elsewhere, in order to accomplish the republication within a reasonable time, and without irespassiug too much upon our limited space. Though we shall thus depart a little from the expressed intention of only publishing original matter in this Journal, we feel assured that all our readers will be pleased to have brought before them descriptions of Canadian insects to which they can hardly otherwise obtain access. For convenience of reference, the paging of the origiual work, and any notes we may add, will be enclosed in square brackets.

\section{[8] Famity Gicindelide. \\ * Labrum unidentate.}

1. Cicndera hirtcolus, Say.-Locality not stated. [For description, vide Say'a Ent. ii. 423.]

[9] 2. Cichinded REPanda, De Jean.-Locality not stated.

Very like the preceding species, but the labrum is shorter and less prominent in the middle; the lateral margin of the elytra is not continuously white; 
the lower limb of the humeral crescent slopes towards the apex of the elytrum; the broken or S-shaped band terminates in a streak at the margin; all the warkings also of the elytra are buff coloured rather than white; and the minute mucro or point that terminates the suture, and the serrulations of the apex of the elytra are less conspicuous.

De Jean regards this species as synonymous with $C$. hirticollis, but, if I am correct in my reference to him, of which I have little doubt, they are clearly distinct.

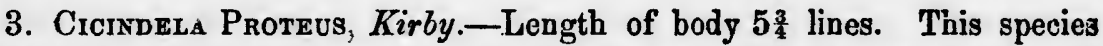
of which several specimens were taken in the expedition, appears to abound in North America. Dr. Bigsby met with it in Canada, and there was a specimen in the late Mr. Marsham's collection, probably from the United States.

Similar to $C$. repanda, but instead of the humeral and terminal crescents, in all the varieties, are four white dots, two at the base and two at the apex of the elytra; the middle broken or tortuous band resembles the figure 7 reversed, and does not terminate in a marginal streak. The body underneath, as usual, is golden-green, or green with clouds of blue, above it is dark-brown with a tint of copper.

Variety $B$. With the apical dots not larger than the humensl.

C. With an interrupted crescent at the apex.

$D$. With three apical and two humeral dots; intermediate band internally abbreviated.

$E$. Like the last, but with only one humeral dot.

[This is $C$. duodecim-guttat a, Dej.; it is commonly taken in many parts of Canada.]

\section{* Labrum tridentate.}

[10] 4. Cicindula obliquata, De Jean.-Many taken in the expedition, and apparently abundant in North America. I received it many years since, but without a name, from my lamented friend Prof. Peck.

Body above greenish-copper, underneath golden-green clouded with blue. Labrum white, tridentate, slightly prominent in the middle; mandibles white at the base, black at the tip; palpi black; labial with the intermediate joint rufous, darker at the tip. Elytra with a large white humeral crescent, extended at the lower end obliquely beyond the middle; mesal band bent down. wards, recurved at the end, and connected by a marginal line with a crescent at the apcr. In the male the intermediate joint of the labial palpi is white, and the mesal band is not connected with the terminal crescent.

[Le Conte (Pro. Acad. Nat. Sci. Phil., Dec. 1866, p. 362) states that this species should hereafter be known as $C$. Kirbyi, since, as he learns from a 
drawing made by Mr. Andrew Murray, from the type in the British Museum, it is quite distinct from any species known to him ]

5. Cicinnela volgaris, Say.-A common species in all North America.

[11] 6. Cicindela purpurea, Oliv. - [Very common in most parts of Canada.]

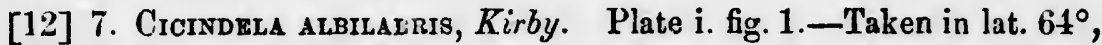
and also in Canada by Dr. Bigsby. [Previously described as $C$. longilabris, by Say. (Ent. Works, i. 176.) We have received specimens of this species from Nova Scotia, collected by Mr. J. M. Jones, and from Quebec and New Hampshire.]

\section{[Family Carabide.]}

[13] 8. Casmonia Pensuguanica, De Jean.-Two specimens taken.

9. Cymindis maroinatus, Kirby.-Piceous, thiekly punctured; antennæ, mouth, dilated sides of the protborax, lateral margin and shoulders of the striated elytra, and legs, rufous. Length of the body $4 \frac{1}{2}$ lines.

One specimen of this insect was taken in the route from New York to Cumberland House, and the other in lat. $65^{\circ}$. It is nearly related to $C$. pubescens, Dej., but appears distinct.

[14] Body depressed and flat, as in its congeners, piccous; above densely punctured; mouth rufous : antennæe longer than the prothorax, piceo-rufous; front betwein the eyes tranversely wrinkled; prothorax convex, with a longitudinal channcl; lateral margin dilated, reflexed and rufous; elytra striated or slightly furrowed, with the furrows and their interstices punctured ; viewed on one side they appear hairy with upright ferruginous hairs; their shoulders and lateral nargin are obscurely rufous; their apex obliquely truneated, and subemarginate; the legs are rufous.

Var. B. Piceo-rufous; elytra concolorate.

[In Melsheimer's Catalogue, p. 4, this species is put down as a synonym of C. cribricollis, Dej., and in Le Conte's List, p. 6, with a mark of interrogation under $C$. reflexa, Lec. The latter author, however, subsequently states (Trans. Am. Ent. Soc., Feb. 1869, p. 244), that both C. Marginata, Kirby, and $C$. reflexa, Lec., are identical with $C$. cribricollis, Dej. The species occurs in the most northern parts of the United States and in Canada.]

10. Crmindis unrcolor, Kirby.-CThickly punctured, ferruginous; legs paler; lateral margin of the thorax not dilated. Length of the body $3 \frac{1}{2}$ lines. One specimen only taken.

This species greatly resembles variety $\mathbf{B}$ of the preceding. It is, however, smaller and paler; the prothorax has no longitudinal channel, and its lateral margin is not dilated. 
[Placed, with a mark of interrogation, as a synonym of $C$. neylecla, Hald., in Le Conte's List, p. 6.]

\section{Genus Sericoda Kirby.}

Labrum transverse, sub-quadrangular : with the anterior angles rounded Mandibles acute, incurved at the apex, not toothed? Labium [mentum] emarginate with a minute tooth in the sinus. Palpi: maxillary 5-jointed; first joint very minute, second longer than the rest, sub-cylindrical, attenuated at the base; third ob-conical ; fourth as long as the third, fusiform, truncate; ffth very minute, retractile within the fourth : Labial 3 -jointed; joints nearly equal in length; the two first conical; the last fusiform, truncated. Antennce rather incrassated toward the apex; scape ${ }^{1}$ incrassated; 2 nd joint the shortest, and the third rather longer than the others.

[15] Body depressed, narrow. Head triangular. Eyes large and prominent. Neck very little constricted. Prothorax short, channelled, widest anteriorly; with the angles rounded. Elytra obliquely truncated at the apex and emarginate, so that internally they terminate in an acumen. Cubit [tibia of 1st pair of legs] emarginate. Tarsi with the penultimate joint entire. Claws sirggle, not pectinated.

The maxillary palpi of the genus here defined present an anomaly observed in no other known coleopterous genus, they appear to be furnished with a miuute fifth joint retractile within the fourth. In one of these palpi, in the only specimen taken, this little accessory joint is not apparent, but in the other it is distinctly seen emerging from the fourth joint, or rather, as this last appears broken at the apex, it is uncovered. There is only one supposition that can reconcile this case to the general rule, that no coleopterous maxillary palpus shall exceed four joints, namely - that this is an effort of nature, by a reproduction, to restore the mutilated organ so as to fulfil its functions. Did the insect belong to the Crustacea or Arachnida this would be a satisfactory explanation of the anomaly, but I do not recollect any instance upon record of a genuine insect having reproduced a lost organ. I thought it possible that the palpi of other Predaceous beetles might contain a retractile joint, and this truncated apex seemed in some degree to favcur the idea, but I did not succeed in my endeavours to discover one. [Mr. Scudder (Fro. Bost. Soc. Nat. Hist. xii. 99) describes the reproduction of lost limbs in the Walking-Stick Insect (Diapheromera femorata), specimens of which we have seen in his cr.binet. We cannot but think that the case described abeve by Mr. Kirby is an instance of reproduction.]

\footnotetext{
1 Scape. The first, and oiten most conspicuous joint of the antennæ, terminating below in the bulb, which inoscrlates in the head, and acts the part of a rotula. [Definitions, dc., p. Ivii.]
} 
The above structure of the palpi, if not accidental, seems to give our little insect some utfinity with the Subulipalpi of Latreille, but its general charac ters and aspect appear to demand a place for it somewhere between those Truncipennia whose claws are not pectinated, and those who have those crgans so armed.

11. Sericoda bembidioidrs, Kirby.-Plate 1, Fig. 2.-Black underneath, above black-bronzed, rather silky; prothorax sub-trapezoidal, with a pair of impicssions behind; elytra substriated, impunctured, somewhat clouded, with a series of impressions adjoining the suture. Length of body $3 \frac{1}{4}$ lines. Only a single specimen taken.

[16] Body underneath black glossy; above the black has a brassy tint, with somewhat of the lustre of silk; head, between the eyes marked with a short, anteriorly forked furrow; prothorax sub-trapezoidal, anteriorly subemarginate, sides oblique with the margin reflexed, transversely very minutely wrinkled, with a pair of anterior excavations in the disk, posteriorly also somewhat impressed on each side; elytra longer than the head and prothorax together, slightly furrowed with imnunctured furrows, obsoletely clouded: there is a series of about five shallow impressions near the suture.

[Included by LeConte in the genus Plutynus. Has been taken in Oregon.]

12. Bracminds cyannipenvis. Say.-[Say's Ent. Works, ii. 91.] Several specimens of this insect were taken in the journey from New York to (umberland House, and in lat. $54^{\circ}$; it was taken also in Canada by Dr. Bigsby.

[17] 13. Carabus Vietingmovir, Adams.-(Mem. Soc. Nat. Moscow, iii. 170 ; Fischer Ent. Russ. i. 98 ; Dej. Coleopt. ii. 61, 21.) Kirby, plate I., fig. 3. .

9. Length of the body 10 lines. Body very black and glossy. Head - punctured between the eyes wilh confluent but not minute punctures; anterior part of the front wrinkled on each side, but the nose and upper lip are quite smooth; the seven terminal joints of the antennæ are brown; the prothorax is nearly square with the sides rounded anteriorly and the posterior angles a little proninent; it is deeply channelled, transversely wrinkled in the disk, confluently but not minutely punctured on the sides; the disk also is black, but the sides exhibit shades of dark blue and green, at the margin they are of a most brilliant ruddy copper, some of the anterior punctures also appear as if gilded; the elytra are rough and as it were retieulated with longitudinal and transverse elevations, the former vearly arranged in lives which produce deep cavities; the disk is of a fine deep blue, the sides green, and the lateral margin of the same ruddy copper as that of the prothorax. The body underneath is quite smooth in the disk, with some irregular elevations and depressions on the sides : the sides of the ante-pectus, or fore breast, are of a fine 
green; the intermediate segments have each a pair of impressions from which a hair emerges. This is most visible in the $\delta$.

I at first regarded this splendid insect as a new species. I thought it, indeed, very near $C$. Vieting? hovii, but as it did not altogether agree either with Dr. Fiseher's figure or description, and was found in another quarter of the globe, I regarded it as distinct; but having received from my friend, Mr. Hope, a Russian specimen of that insect, I find no difference sufficient to constitute a species. In that speeimen the marginal gilding of the prothorax and elytra is greener with scarcely any of the ruddy hue of copper which gives slich brilliance to the American specimen.

[A single specimen only of this magnificent beetle was brought to Mr. Kirby in the Richardson collection, and no locality is given of its capture; can it have come from Russia, and not from British America? No specimen of it has been taken in this country, so far as we are aware, sinee the time of that expedition, a period of orer 30 years. It might have been included in the collection by some accident-a not infrequent occurreuce. Prof. Croft, for instance, writes us that some years ago he liad a collection of moths given to him "collected in or near Toronto," yet among them was a gigantic Chinese "Saturnia: He adds, that on looking iato Fischer's work he finds the habitat for the insect is "Eastern Siberia-banks of the Lena."]

[18] 14. Carabus Lrgates, Knoch.-Taken in Canada by Dr. Bigsby" Length of body $7 \frac{1}{2}$ lines.

Body black and glossy. Head oblong, impunctured, separated from the neek by a transverse slender curving ridge forming anteriorly a deep sinus; ridge, defending the base of the antennæe, conspicuous; frontal impressions long, not deep; antenna not much longer than the prothorax; prothorax nearly square, blaek slightly bronzed; sides lightly punetured, lateral margin refiexed; it is faintly channelled, depressed transversely at the bise, with a punctured impression on each side; elytra bronzed, sub-depressed with searecly any sinus at the apex, lateral margin refexed and carinated; each elytrum with 13 or 14 rows of impressed punctures; a triple series of oblong discodial elevations; interstices with numerous trausverse linear impressions: abdomell underneath smooth with a few minute punctures on the sides.

The insect here described agrees with Germar's deseription of Knoch's $C$. ligatus, but it is doubtful whether it be synonymous with $C$. carinatus of DeJean. In most respects, indeed, it accords precisely with his description, but the head is not slightly punctured, as he states his specimens to be.

[Botb C. ligatus and $C$. carinatus are included as races of $C$. vinctus, Weber, by LeConte, in his List of Coleoptera, p. 3.]

[Kirby divides the genus Calosoma into two sub-genera : Calosoma proper having the maxillary palpi with the last joint of the length of the last but 
one, and the elytra gilded; Chrysostigma having the maxillary palpi with the last joint shorter than the last but one, and the elytra obscure with gilded punctiform impressions. The two species that he describes both belong to the latter sub-genus. Dr. Lo Conte (Pro. Acad. Nat. Sci. Phil., Feb. 1862, p. 52) has given a more complete classification of the species of this genus into six groups, based upon the differences of the anterior tarsi of the males. Kirby's division has hot been adopted by subsequent authors.]

[19] 15. Calosoma calipum, Fab. This species is very common in all parts of North America; several specimens were taken in the expedition.

16. Calosoma frigidum, Kirby.-Length of the body $9 \frac{1}{3}$ lines. Taken in Drummond's Island, Cauada, by Dr. Bigsby.

Not unlike C.calidum, but longer in proportion and more depressed. Body black, not glossy above. Head confluently punctured and wrinkled : mandibles obliquely but less densely wrinkled, and frontal impressions longer t.an in C. calidum: prothorax seareely at all bronzed, lateral margin obscurely green, with the same nun.jer of elevated lines as in $C$. caliclum, but in the furrows formed by them is a series of punctures, and the transverse lines are less ecnspicuous; there is a triple series of punctiform impressions, but they are bilobed, smaller, and the gilding is greenish and less conspicuous; they are also less numerous, there being only seven or eight in the series next the suture, eight or nine in the intermediate one, and three only towards the apex in the external one : at the base there is also a pair on each side : the sides of the body underneath are greenish, punctured and wrinkled.

[20] 17. Helobia [Nebria] castanipes, Kirby.-Length of body 5 lines. Two specimens were taken in lat. $65^{\circ}$.

Body black, glossy. Antennæ, mouth, nandibles, and palpi pale chesnut or mahogany colour; the former more dilate at the apex; front with three or four slight furrows between the eyes; upper-lip very short: prothorax heart-shaped, constricted posteriorly, convex in the disk; sides and base depressed and lightly punctured: elytra dark piceous, striated or slightly furrowed : furrows very obsoletely punctured; interstices very flat; between the 2 nd and 3rd furrows, adjoining the latter, are from three to five shallow but rather large impressions: the legs are slender, of a pale ehesnut or mahogany colour, in one of the specimens the thighs are darker than the rest of the leg. N.B.-In one specimen there are three and in the other five impressions.

18. Cackenius sericeus, Forst.-[Say's Ent. Works, ii. 483.]-Several taken in the journey from New York to Cumberland-house. In Canada by Dr. Bigsby. [Very common throughout Canada.] 
[21] 19. Chlanius impunctifrons, Kirby. - [This name is preoccupied by Say; Kirby's species is probably identical with LeConte's $C$. brevilabris.] Juength of body 5-5? lines.

Smaller than $C$. sericeus, though like it. Head without punctures; antennæ black, with the three first joints testaceous : scutellum not acuminate : elytra black with a shade of green; apex of the epiplsuræ or side-covers and legs testaceous; coxæ chestnut. In other respects, this agrees with the preceding species.

20. Chlanius nemoraris, Say.-[Ent. Works, ii. 487.]

A pair taken in the journey from New York to Cumberland-house. [Rare in Canada.]

[2.2] 21. Chlenius QUADricollis, Kirby.-Length of the body six lines. Taken by Dr. Bigsby in Canada.

Body hairy like the others, black underneath. Head and prothorax bronzed-green; mar-libles piceous; palpi and three first joints of the antennæ testaceous; the latter are longer than the thorax, with the 4th joint as long as the šrd; prothorax rather square, a little narrower before, with the sides curving, sculptured like the preceding species; scittellum sub-acuminate : elytra blue-black, furrowed with deeper furrows very visibly punetured, interstices minutely punctured.

[Placed, with a mark of interrogation, as a synonym of C. Pensylvanicus, Say, in Le Conte's List, p. 11.]

22. Chu enius condicollis, Kirby.-Length of the body 8 lines. Taken in Canada by Dr. Bigsby.

Body black. Head impunctured; palpi rufous; antennæ dusky, with the three first joints rufous, the third much longer than the fourth : prothorax obcordate, constricted behind, deeply. channelled, disk gibbous on each side of the channel, centre of each gibbosity smooth, remainder of the prothorax punctured; posterior lateral impression longitudinal: elytra black with a shade of green, sculptured as in the preceding species, but the interstices of the furrows are more visibly punctured : legs testaceous, thighs darker.

[23] 23. Chlanius emarginatus, Say.-Length of the body $6 \frac{3}{4}$ lines. Taken in the journey from New York to Cumberland-house.

Body hairy, punctured; black underneath. Head glossy green, with a tint of copper between the eyes, and a net-work of very minute, confluent, transverse wrinkles; maxilla and palpi rufous, maxillary palpi very long; upper-lip transverse, rufo-piceous, anteriorly subemarginate ; mandibles piceous; antenna rufous, longer than the prothorax, with the third joint rather longer than the 4 th ; prothorax dusky-green, transverse, rather narrowest at the apex, very thick and minutely punctured; basilar impressions double, 

. 
the inner one the longest: elytra black with a very faint tint of blue : legs rufous.

This is most probably the C. emarginatus of Say, but it does not exactly accord with De Jean's species. [Say's $C$. emarginatus belongs to the genus Anumoglossus, Chaud.; the species here described is C. impunctifrons, Say.]

24. Platynus anausticollis, DeJean.-Length of the body 5 lines. Taken in lat. $54^{\circ}$ and $65^{\circ}$. Not uncommon in Britain.

[24] Body very black, glossy, sonewhat narrowed. Head smooth, narrower than the prothorax, including the neck sub-rhombcida!, without it triangular; paipi and antennce piceous; frontal impressions large; prothorax narrower than the elytra, obcordate, longer than wide; dorsal channel deep, terminating anteriorly in a transverse obtuse angular impression; lateral nargin dilated, especially at the base, reflexed, somewhat piceous in a strong light, basilar impressions single, large, round, with a fer scattered indistinct punctures : elytia rather deeply furrowed; furrows very slightly punctured; between the second and third are two punctiform impressions, the anterior one being adjacent to the former furrow, and the posterior to the latter.

[This is considered an erroneous determination by Dr. Le Conte (List, p. $\bar{t}$ ), and is inserted by him as a race of $P$. sinuatus, Dej.]

25. Agoncm (Ancuonexcij) extexsicolle, Say.-[Ent. Works, ii. 478.] A pair taken in lat. 54\%. [Belougs to Ilatyuus ; has been taken in Ontario.]

26. Agonum picipenne, Kirby.-Length of the body 31 to 4 lines. Several specimens taker in lat. $54^{\circ}$.

[25] Body black, glossy. Mouth and its organs rufous, except the upper. lip, which is edged with that colour; antennæ longer than the prothorax; piceous with the scape paler than the other joints : prothorax longer than in the following species, oblong-orate, with the lateral margin piceous, and not dilated posteriorly as in the majority; basilar impressions rather shallcw, oblong: elytra oblong, rufo-piceous, slightly furrowed, furrows impunctured; fire punctiform impressions between the second and third; the three anterior ones adjacent to the latter, and the two posterior to the former: legs dusky rufous.

Variety B. With only four punctiform impressions, legs paler.

C. With the 2nd, 3rd and 4th joints of the antenna piceous, the rest ferruginous : impressions of the elytra as in $B$.

D. Larger, elytra with five impressions, in other respects like $\mathbf{C}$.

This species appears very like $A$. lenim, Dej., which is also North American, but the colour of the underside of the body and of the head and prothorax is different. [Belongs to Platynus.] 
27. Agonum soroens, Kirby.-Length of the body three lines. Two specimens taken in lat. $54^{\circ}$.

Body black, glossy. Head rhomboidal; mouth, mandibles at the tip palpi at the base, and seape of the antenna, rufous; frontal impressions very slight : prothorax scarcely longer than wide, narrowest behind; dorsal cliannel rather deep; lateral margin underneath testaceous; basilar impressions, oblong, deepish : elytra dusky-testaceous, in one specimen a little bronzed, slightly furrowed, furrows impunctured; between the second and third are five punctiform impressions placed as in the last species : epipleura and legs testaceous.

[26] Agonum melanaricm, De Jean.-Length of the body $4 \frac{3}{4}$ lines. Taken in lat. $54^{\circ}$.

Body black, glossy. Mandibles at the tip, morth and scape of antenna, piceous : prothorax nearly as long as wide; disk transversely wrinkled; lateral margin at the base much dilated, rather incrassated, and sub-angular; posterior impressions large and distinctly punctured: elytra wider than the prothorax, sub-emarginate at the base, distinctly furrowed with very minute and inconspicuous punctures in the furrows; three punctiform impressions in the third furrow from the suture : legs piceous.

This species is the American represcutative of $A$ versutum, which it much resembles. [Belongs to Ilatynus; taken at Ottawa by Mr. Billings.]

29. Agovum seminitioum, Kirby.-Length of body $4 \frac{1}{2}$ lines. Taken in lat. $54^{\circ}$.

Body smooth, glossy, black underneath. Head greenish-bronzed, very glossy, with frontal impressions lunular; antenna longer than the prothorax; prothorax greenish-bronzed with a copper tint, very glossy, channelled, disk transversely and ninutely wrinkled; basilar impressions longitudina!, lateral margin, particularly at the base, reflexed: elytra black-bronzed, less glossy than the head and prothorax, lightly furrowed; furrows punctured; in the interstice between the second and third furrows are five punctiform impressions, two nearer the base and three nearer the apex of the elytrum, so that the interval between the second and third is greater than that between the others.

Varicty B. Second and third punctiform impressions not more distant than the others. In this specimen, on the left hand elytrum, there are only four impressions and on the other five, but in neither are the sccond and third situated as in $\mathbf{A}$. It may be a distinct species, but I ean discover no other difference.

[27] 30. Agonum simile, Kirby. - Length of the body $3+$ lines. Iocality not stated. 
Body glossy, underneath very black, above black slightly bronzed. Antennæe seareely longer than the prothorax: prothorax rather longer than broad; basilar impressions roundish, impunctured : elytra more bronzed than the head and prothorax, lightly furrowed; furrow adjoining the suture more depressed and deepr,r than the rest; in the space between the second and third furrows are five equi-distant punctiform impressions, the two anterior adjoining the latter furrow, and the three posterior the former.

This little species greatly resembles $A$. seminitidum. It is howercr unch smaller, less bronzed, the prothorax is longer in proportion, the sutural furrow is deeper, and the impressiuns are differently arranged.

31. Agonum affine, Kirly. - Length of body 4 lines. Locality not stated. A single specimen taken.

Body very black, glossy. Antenna longer than the prothorax : prothorax of the saine width before as behind, so as to aprear more square than in the preceding species; its lateral margin at the base is likewise not reflesed, the dorsal channel is slight, and the disk is minutely and transversely wrinkled; the basilar impressions are leep, large and eireular; elytra very slightly bronzed; three punctiform impressions, the anterior one adjoining the third furrow, and the two posterior the second. are visible in the usual situation; the four anterior trochanters are of a deep red.

[28] 32. Agonum Erythropum, Kirly.-Tength of body $4 \frac{2}{2}$ lines. Taken in Canada by Dr. Bigsby.

Body glossy, black underneath, above bronzed. Autenna black, with the scape dusky rufous; prothorax tinted with copper, obcordate, with rounded angles; basilar impressions round and deep; elytra tinted with copper, with three nearly obsolete punctiform impressions in the usual situation; legs dusky rutous; in other respects it resembles $A$. seminiticium.

This spccies appears to be the American representative of $A$. parumpunctatum. It is, however, larger, more bronzed, the impressions are less distinet and more distant, and the thighs as well as the tibix and tarsi are rofuus

[The nawe of this species is pre-oecupied by Dejean's P. erythropus; it is placed with a mark of interrogation in Dr. LeConte's list under Ilutymus subcordutus, Jee.]

33. Agonum cupripense, Say. Plate I. fig. 4. - Many specinens of this lovely Agonum were taken in lat. $54^{\circ}$. It appears to be very eoinunon in North America, where it represents $A$. sexpunctatum, the most brilliant of our European species, but which $A$. cupripenne far exceeds in beauty. [Quitc common in Western Canada.]

[29] 34. Calatuus aregarius, Say. - Taken frequently in lat. 54․ [Say, Wnt. Works, ii. p. 472. Taken in both Ontario and Quebec.] 
35. Puatyderus vitidus, Kirby. Plate I. fig. 5. - Length of body 4 lines. Three specimens, all females, taken in lat. $54^{\circ}$.

Body black, glossy; head triangular; mouth piceous; antennæ rather longer than the prothorax, piceous with the terminating joints paler, scape rufous; prothorax subquadrangular, with the posterior angles rounded, emarginate at the base as well as at the apex, slightly channelled, with a pair of linear basilar impressions on each side, the external one being oblique and the other longitudinal; elytra rather deeply furrowed, with two punetiform impressions in the usual situation; viewed in the sun, the elytra exhibit changeable shades of bluc and bronze; forebreast piceous; legs clear, testaceous. [Previously deseribed as Feronia, (Pterostichus) erythropus, by Dejean.]

[30] 36. Argutor bICOLOR, Kirby. - Itength of body 3 lines. Tilken twice in lat. $54^{\circ}$.

Body glossy; above black, beneath mahogany coloured; antenna and palpi at the base dark mahogany colonr; prothorax longer than wide, ratiner narrowest at the base, where it is slight!y sinuated, anterior angles rounded, without punctures, dorsal channel slight, a deep short basilar furrow on each side; elytra slightly furrowed with impunctured furrows, the seventh from the suture obsolete; in the interstice between the second and third are three puactiform impressions, the anterior one adjoining the latter and the two posterior snes the former.

This species approaches very near to $A$. erythropus, Dejean, but it is smaller, and the posterior angles of the prothorax are not rounded. The under side of the bolly, the legs and antenne, are all of the sane colour, sometimes a little darker, at others a little paler. ['The genus Argutor, Meg. is now included in Pterostichus.]

37. Argutor [Pterostichus] frmoralis, Kirby.-Length of the body $3 \frac{1}{2}$ lines. Taken in lat. $54^{\circ}$.

This species approaches very near to the preceding one, and its place is between that and $A$. verna'is, of which it is the American representative. It differs from $A$. bicolor chiefly in having only the scape of the antennæ and the tibia and tarsi of a different colour from the rest of the budy, and in having the anterior half of the furrows of the elytra slightly punctured; and from the latter in having the prothorax narrower at the base, with only a single impunctured iupression on each side. [We have received a specimen of this species, taken in the United States, from our friend Mr. F. G. Sanborn, of Boston, Mass.]

[31] 38. Argutor [Pterosticirus] Mannibularis, Kirby. - Length of the body $3 \frac{1}{2}$ lines. Taken in lat. $54^{\circ}$. 
Body glossy, underneath black, above black-bronzed; mandibles, palpi, scape of antennæa and legs rufous, or rather pale chestnut ; frontal impressions rather wide; prothorax truncato-obcordate, with a basilar furrow on each side and a few punctures at the posterior angles; elytra lightly furrowed, with punctures in the furrows ; two punctiform impressions in the usual situation, one a little beyond the middle of the elytrum, adjacent to the second furrow, and the posterior one near the apex adjacent to the third.

Variety B. Black above, with the whole antennæ rufous, elytra piceous; perhaps an immature specimen.

39. Argutor [Pterostichus] brevicornis, Kirby. Plate viii. fig. 3.Length of body 3 lines. Taken in lat, $65^{\circ}$.

This with the preceding species, in the shape of the prothorax, which is obcordate, departs a little from the others. A. brevicornis resembles A. mandibularis in many respects, but the body is black, as are also the mandibles and palpi; the antennæ of the male are shorter, and those of the female not longer, than the prothorax ; one of these organs in the latter sex, in the only $\$$ specimen taken, appears to have been affected by some disease, for the two last joints are larger than the preceding ones, so as to form a kind of knob; it is the right-hand antenna that is so circumstanced; the little furrows at the base of the prothorax are wider than in A. mandibularis; the elytra of the $\delta$ have three, and those of the $q$ four, punctiform impressions, all adjacent to the third furrow. The last eight joints of the antennæe in this species have less down and shine more than is usual with the ground beetles in general.

[LeConte, in his list, asks whether this species may not be equivalent to $P$. fasticliosus. Mann.]

[32] 40. Onaseus [PTerostichus] orinomum, Leach.- Length of body $5 \frac{1}{2}$ lines. Taken frequently in lat. $54^{\circ}$ and $65^{\circ}$.

Body oblong, glossy, black. Head rather ovate, underneath, in some specimens, chestnut, in others black; palpi piceous; prothorax subcordate, rather longer than wide; a deep, punctured, basilar impression on each side; posterior margin slightly sinuate; elytra subacuminate, lightly furrowed with from four to six largish impressions in the second and third furrows, the first usually being in the third and the second on the second furrow, but the others occasionally varying; the natural number of these impressions seems to be five; legs black, with piceous tarsi.

Variety B. Legs chestnut.

C. Tibiæ and tarsi chestnut.

From the number of specimens collected in the expedition, I should conjecture this to be one of the most common of North American insects. It 
appears, however, not to have been noticed by Say, nor was it amongst those collected by Dr. Bigsby in Canada, or by Dr. MacCulloch and Capt. Hall in Nova Scotia. [According to LeConte an erroneous determination $f_{i}: P$. luczotii, Dej., a species taken in Ontario and Quebec.]

41. Omaseus [Pterostichus] nigrita, Curtis.-[This is $P$. caudicalis, Say (Ent. Works, ii. 480); it has been taken at Ottawa by Mr. Billings.]

[33] 42. Onaseus [Ptrrostichus] picicornis, Kirby.-[Previously described as $P$. mutus by Say (Ent. Works, ii. 470); taken in Canada and the United States.]

[34] 43. Stereocerus [Amara] similis, Kirby.-Plate viii. fig. 1.Length of body 51 lines. A pair were taken in lat. $54^{\circ}$.

Body of a piceous-black, glossy. Palpi piceous; antennæ chestnut; frontal inpressions deep, rather curving; occiput punctured with scattered punctures; prothorax nearly square with curved sides; basilar impressions wide, punctured, deeply bisulcate, with an elevated little ridge between them and the margin: elytra bronzed, furrowed, furrows scarcely punctured : legs pale chestnut. In the $q$ the elytra are not bronzed, the legs are darker, and the terminal joint of the palpi is longer.

[35.] Curtonotus [Amara] convexiusculus, Stephens.-Length of body $5 \frac{1}{4}$ lines. Taken in lat, $65^{\circ}$.

Body dark piceous, sometimes a little brouzed. Antennæ and palpi rufous; frontal impressions short, connected by a rather deep furrow ; prothorax constricted and punctured at the base, depressed on each side; basilar impressions bisulcate ; posterior angles acute, recurved ; elytra furrowed, furrows punctured: sides of the ventral segments of the abdomen somewhat punctured and wrinkled, those of the mid-breast grossly punctured: legs chestnut.

[LeConte considers this an erroneous determination, and places it, with a mark of interrogation, as a synonym of his 4 . laticollis, stating (Pro. Acad. Nat. Sci., Phil., Jnne, 1855, p. 347,) respecting the latter that it is "found in Nebraska Territory near the Rocky Mountains. Very similar to the European $A$. convexiuscula, but in comparison with that species the thorax is more rounded on the sides, more narrowed behind, and more finely margined."]

45. Curtonotus [Amara] rufimanus, Kirby.-Length of body 5 lines. Several taken in lat. $54^{\circ}$.

This is extrenely similar to the species last described, from which it principally differs in having the legs of the colour of dark pitch, with the exception of the hands or anterior tarsi, which are rufous : the sides of the ventral segments of the abdomen also appear less conspicuously punctured. 
[LeConte (loc. cit. p. 356) states that this is "probably a variety of A. laticollis, Lec., in which case the name will not have preference, as the description must be considered worthless, and moreover must be considered as erroneously separated from $A$. convexiuscula, Kirby." He makes the same remarks also upon the two following species: $C$. brevilabris, Kirby, and $C$. latior, Kirby.]

45. Curtonotur Brevilabris, Kirby.-Length of body $4 \frac{1}{3}$ lines. A single specimen taken in lat. $65^{\circ}$.

[36.] Like the preceding species, but smaller: the upper lip is blacker, not half so long and slightly emarginate: the elytra are dark, and the legs pale chestnut; the furrows of the former are less conspicuously punctured; the frontal impressions likewise are longer and connected by a slighter furrow.

47. Curtonotus lation, Kirby.-Length of the body 5 lines. One specimen only taken.

This species has a good deal the aspect of Bradytus apricarius, but it is a larger insect and rather wider in proportion, and the bifid intermediate tooth of the lower lip proves that it is a true Curtonotus. Body piceous, above bronzed. Upper lip, palpi, antennæ, side-covers, and legs, a!l rufous; nose at the anterior margin has an obtuse-angular sinus ; frontal impressions punctiform, connected by a slightly-drawn line or furrow: prothorax wider than long, the lateral margins forming a segment of a circle without any posterior constriction; at the base the prothorax is depressed, the basilar impressions are bisulcate, the inner furrow being the longest: furrows of the elytra punctured.

48. Pecildos [Pterostichus] Lucublandus, Say.-Many specimens taken in lat. 54 ${ }^{\circ}$. [Excessirely common in Canada; for description vide Say's Ent. Works, ii. 478.]

[37] 49. Pocilus [Pterostichus] castanipes, Kirby.-Length of body $5 \frac{1}{2}$ lines. One specimen only taken.

This species differs from variety $\mathbf{D}$ of $\boldsymbol{P}$. lucublandus ("entirely black, with the sides of the prothorax impunctured, elytra violet"), which it much resembles, it being entirely black; in having slighter basilar impressions, less distinctly punctured: it has likewise only three punctiform impressions on the elytra, the granular reticulations of the substance of which are also more easily discovered. [Considered to be merely a variety of P. lucublandius by LeConte.]

50. Pcecrus [Pterostichus] chalcites, Say.-Only a single specimen taken.

[Not uncommon in Canada; for description vide Say's Ent. Works, ii. 479.$]$ 
51. Amara volgaris, Latr.-Length of body 4 to $4 t$ lines. Manj pecimens taken in lat. $65^{\circ}$, and in the Rocky Mountains.

Body black, glossy; above black-bronzed. Scape of the antennæ pic:ous; inner lobe of the maxillse, and first joint of the outer palpi, testaceous; basilar impressions of the prothorax double, deepish, impunctured, the external one oblique; channel abbreviated anteriorly, with a punctiform impression beyond the middle : furrows of the elytra lightlodrawn, indistinctly pnnctured; apex subacuminate or suddenly narrowed: legs black, with the hairs, spurs and claws testaceous.

Variety B. Bright, bronzed with a cupreous tint.

C. Wholly black.

[An European species, unknown to Dr. LeConte. Stated by Mr. William Couper-but probably erroneously-to be common at Toronto.-Can. Jour. 1855 , p. 256.]

[38] 52. Amara infequalis, Kirby.-Length of body 4 lines. Several taken in lat. $54^{\circ}$.

Very like $A$. vulgaris, but the $t w o$ first joints of the antennæ are rufous ; the basilar impressions of the prothorax are not so deep; and the interstices of the furrows of the elytra are convex and uneven : in other respects there is little difference between them. [Previously deseribed as $A$. intersititialis, Dej.; taken, according to Dr. LeConte (Pro. Acad. Nat. Sci., Phil., June, 1855, p. 353), on Lake Superior, at Fort Simpson, Mackenzie River, and in Massachusetts, Pennsylvania and Illinois. Also found at Grimsby, and other places in Ontario.]

53. Amara impuncticollis, Say.-Taken in lat. 54. [Common in Canada ; for description vide Say's Ent. Works, ii. 463.]

54. Amara pallipes, Kirby.-Length of boày 3 lines. Only one specimen taken.

Body glossy; underside, mandibles, coxæ and tarsi piceous; upperside bronzed. Three first joints of the antennæ rufous; frontal impressions very slight, connecting line very distinct : dorsal channel of the prothorax nearly entire; basilar impressions rather punctiform, punctured ; elytra not subacuminate: legs yellowish. [Taken on Lake Superior and in Northern New York, according to LeConte ; also in Ontario.]

[39] 55. Amara laevipennis, Kirby.-Length of body $3 \frac{1}{5}$ lines. Three or four specimens taken in lat. $54^{\circ}$.

Body glossy; the underside, legs and antennæ black; upperside blackbronzed : frontal impressions very slight : prothorax smooth, with the basilar impressions very faint: furrows of the elytra very lightly drawn, and some- 

, 
times subinterrupted; intermediate trocbanters piceous. ["Lake Superior, one pair; a female from Massachusetts, sent by Dr. Harris" (LeConte).]

56. Amara discors, Kirby.-Length of body 4 lines. One specimen only taken.

This species has somewhat the aspect of a Marpalus, but it exhibits the true characters of Amara: it apnears to be related to $A$. discrcpans, Stcphens. Body dark piceous, glossy. Upper-lip, palpi, mouth and antennæ ferruginous: prothorax a little narrowed bchind; bend of the lateral margin rufous; basilar impressions rather slight: elytra less glosey than the rest of the body, the infinitely minute and numcrous granular reticulations of thcir substance being more conspicuous than usual; the furrows of the elytra from minute punctures exhibit a slight appearance of crenulations : legs pale chestnut. [Unknown to Dr. LeConte; the student of the Amarx is referred to his paper on this genus in the Pro. Acad. Nat. Sci. Phil., June 1855, p. 346, for much valuable matter and fuller descriptions.]

[40] 57. Harpalus pleuriticus, Kirby.-Taken frequently in lat. 54 [For description vide Mr. Sprague's Carabide, Can. Enrom. ii. p. 96. Taken in Ontario and, according to Dr. LeConte, in Minnesota and Winnipeg.]

58. Harpalus i isrlaris, Kirby.-Length of body 4 lines. Taken with the preeding, and in equal numbers.

This species differs from the preceding, which it nearly rescmtles, in having the two first joints of antenna yellow, and the remainder dusky; in having the prothorax still wider in proportion to its length, with its posterior angles more acute and impunctured, and with narrower basilar inpressions also without punctures; its lateral margin is also black and less prominent: the side-covers of the elytra are likewise black : the legs are dark-piceous, with yellowish-red trochanters. In other respects it resembles $\Pi$. pleuriticus. [Unknown to Dr. LeConte.]

[41] 59. Harpalus ochropus, Kirby.-Length of body $3 \frac{1}{2}$ lines. [No locality stated.]

This comes very near $H$. pleuriticus, but is considerably smaller; the antennæ are longer; the prothorax is impunctured at the base, its basilar impressions are linear; the side-covers of the elytra are chesnut; and its thighs are more robust in proportion. [Unknown to Dr. LeConte; supposed by him to be perhaps $H$. desertus, Lec.]

60. Harpulus interpunctatus, Kivby.-Plate vii. fig. 8.-Iength of body $5 \frac{1}{2}$ lines. Many taken in lat. $54^{\circ}$.

Body proporticnally longer than in the antecedent species, black, glossy, not depressed. Head triangular, with a pair of confluent red dots, visible only in the san, between the ejes; antennæ shorter than the prothorax, with 
the seapo and last joint of the palpi rufous: prothorax subquadrangular; anterior angles rounded; dorsal channel drawn from the apex to the base punctured especially posteriorly, disk impunctured, transversely wrinkled; besilar improssions shallow; lateral margin dilated posteriorly; clytra rather deeply furrowed, furrows impunctured, interstices convex, very minutely but not thickly punctured : the four anterior tarsi of the male are furnished with a thick brush of vesicles, not arranged in a double scries, as in other species of this genus. [Placed, with a mark of interrogation, in LeConte's List, as a synonym of Anisodactylus melanopus, Hald., a species taken in Canada.]

[42] 61. Harpalus longior, Kirby - Length of body 5 t to $7 \frac{1}{3}$ lines. Two specimens taken, the largest in lat. $54^{\circ}$.

Body black. Upper-lip piceous; antennx, palpi and legs reddish-tawny, the first longer than tho prothorax; the nose terminates anteriorly in a reddish membrane or rhinarium : prothorax quadrangular with all the angles rounded, rather longer than wide; dorsal channel anteriorly abbreviated; lateral margin minntely punctured, much depressed, especially at the posterior angles; basilar impressions double, shallow, and minutely punctured; elytra very little glossed, more than twice the length of the prothorax, furrows impunctured with conrex interstices, the lateral ones with somo scattered very minute punctures; the vesicles on the sole of the four anterior tarsi of the male are arranged as in the other Harpali.

Both the specimens taken in the expedition are males, or I should have supposed the unusual difference in their size was sexual : probably the small one was taken in a higher latitude. [Unknown to Dr. LeConte; thought by him to be perhaps $H$. vagans, Lec.]

62. Harpalus caticollis, Kirby.-Length of body $5 \frac{1}{2}$ lines. A single specimen taken.

This insect very closely resembles $\boldsymbol{H}$. interpunctatus; it differs principally in having a rather wider prothorax with all the angles rounded, with the dorsal channel abbreviated anteriorly, and with only the base very indistinctly punctured; the interstices of the furrows of the elytra are also without punctures, and there is a single punctiform impression in the usual situation adjacent to the second furrow. [Previously described as.Anisodactylus nigerrimus by Dejean.]

[43] 63. Harpalus [Anisodactylus] Carbonarius, Say.-Two spocimens taken in lat. 54 ${ }^{\circ}$. [Taken also in Canada; for description vide Say's Ent. Works, ii. p. 460.]

64. Harpalus rotundicollis, Kirby.-Length of body $5 \frac{1}{2}$ lines. Two specimens taken.

Body brownish, black, glossy. Antenne length of the prothorax, as well as the tip of the palpi, rufous: prothorax wider than long, with rounded 
angles; basilar impressions shallow, round and punctured: the elytra exhibit a sillyy lustre from the granulations on the surface; there is a single punctiform impression in the usual situation near the apex; in this and the following specics these organs are transverscly truncated with a slight sinuosity; legs rufous or rufo-piceous, with black thighs; cosac and trochanters rufous. [A variety, according to Le( 'onte, of $H$. a mputatus, Say (Ent. Works, ii. 546), a species taken in " Kansas, New Mexico, Saskatchewan, Montreal, Canada."]

[44] 65. Harpalus Stephensir, Kirly. - A single specimen, taken in lat $54^{\circ}$. [A synonym of II. amputatus, Sav.]

[45] 66. Stenolophus versicolor, Kirby.-Length of body $2 \frac{1}{2}$ to $2 \frac{3}{4}$ lines. Three specimens were taken in lat. $54^{\circ}$.

Body dusky-black, glossy. Palpi, mouth and scape of the antennx rifous; prothorax scarcely longer than wide, rounded behind, with the basilar impressions punctured : elyira reddish-brown,-riewed in the sun or in the light, they exhibit a changeable tint of violet; a punctiform impression adjoins the second furrow; apex slightly sinuated; epipleura ycllow: thighs dusky, especially the posterior pair, which are larger tban the uthers; tibiæ and tarsi rufous.

The female has less of the violet tint, and the elytra are of a pale mahogany colour.

Variety B. With the two first joints of the antenna rufous; legs yellow. [Previously described as $S$. fuliginosus by Dejean; is taken in Ontario.]

67. Trechus [Bradrcellus] tibialis, Krirby. - Length of body $2 \frac{3}{4}$ lines. Only a single specimen taken.

[47] Body black, somewhat glossy. The tip of the palpi and scape of the antenwæ are rufous; the prothorax is rather wider than long, but nearly square; the short basilar furrows observable in Argutor distinguish this species from the succeeding ones: elytra lightly furrowed, furrows inpunctured; in the usual sitaation adjacent to the sccond furrow a little beyond the middle of the elytrum a very minute punctiform impression is just discernible; the lateral mergin and suture at the apex of the clytra are reddish : the tibia are rufous but the cubit is black at the tip; the tarsi are darker, the hand has four dilated joints as in the other species of the genus.

[Belongs to Bradycellus; for a synopsis of the N. American species by Dr. LeConte, vide Pro. Acad. N. S. Phil., Dec. 1863, p. 379.]

68. Trecinus [Bradyceluds] Ruficrus, Kirby.-Length of body $2 \frac{1}{6}$ lines. Only one specimen taken.

Body black, glossy. Palpi piceous; scape of the antennæ and mouth rufous : prothorax subobcordate; chanelled, channel not abbreviated, margin 
rufous especially the basilar; angles rounded; basilar impressions single, round and punctured : elytra lurid or dirty yellow, with a large blackish cloud or bloteh beyond the middle: legs dull rufous, thighs darker. [Included by LeConte, loc. cii., under $B$. bacliipennis, Hald., a species taken at Grimsby, Ont., by Mr. Pettit.]

69. Trecirus [Bradycellus] flavipes, Kirly.-Length of body $2 \frac{1}{3}$ lines. Many taken in Isat. $54^{\circ}$.

[48] Body piceous, glossy. Head undiraeath, nose, mouth, and oral organs-execpt the palpi which are pale yellow-and antennæe rufous; three first joints of the latter paler than the others: prothorax rufous, rather longer than wide, between square and obcordate; basilar impressions single, very slight, punetured, and black : elytra rufous, with a broad black stripe adjoining the suture and parallel with it; furrows rether decp, impunctured: legs pale ycllow.

N.B.-In the wajority of specimeas the black stripe of the elytra is very faint, aud in some evanescent, and the impressions as well as the rest of the prothorax rufous. [Previously described as B. rupestris, Say.-Ent. Works ii. 505. Very common in Canada.]

70. Trechus munusis, Kirby.-Length of body $1 \frac{8}{4}$ lines. Two specimens taken with the preceding species.

Similar to $T$. fluvipes but smaller, the nose is piceous, the thorax is more dusky; dorsal channel indistinct; basilar impressions deeper and impunctured : elytra dark piceous with merely the bead of the lateral margin rufous; the furrows also are wore lightly drawa: legs darker. [Le Conte, loc. cit., states that he has not identified this species, but that it is perhaps Stenolophus carus, Lee, though the description is searcciy sufficient to warrant the placing of the latter in synonymy.]

71. Trechus [Bradyceluts] simuis, Kirly.-Length of body $3 \frac{1}{4}$ lines. Two specimens taken in Lat. $54^{\circ}$.

Body black, glossy. Nouth reddish jellow; palpi yellor ; upper-lip and mandibles rufuus, the latter black at the tip; antennæ dusky-rufous, three first joints more yellow: prothorax between obeordate and square, with the whole of the kase distinetly and grossly punctured; basilar impressions shalluw; limb of the prothoras is reddish-yellow, the disk is occupied by a large square blacs spot: the suture, latera! margin, and apex widely, and the inner base of the elytra, are reddish-jellow; [49] adjoining the suture is a broad black stripe not reaching the apex; the furrows are rather decp and impunctured; and in the usual situation, a little boyond the middle, a punctiform impression is adjacont to the second furrow: the sides of the fore-breast, the anus and the legs, are reddish-yellow. 
Var. B. Thoras without a black spot in the disk, body underncath piceous. [Previously described as Feronia atrimedius by Say.-Ent. Works ii. 466.]

[50] 72. Isopheurus Nitidus, Kirly.-Plate i. fig. 6. Luength of body $3 \frac{1}{4}$ lines. A single specimen taken in the Rocky Mountains.

Body very glossy, underneath rufo-piceous, above bronzed with a light tint of piceous. Upper-lip rufous; palpi, antennæ which are slender, side-eover of the elytra and logs reddish-yellow: prothoras rather wider than long, punctured posteriorly, basilar impressious doubled: furrows of the elytra slightly punctured, at the apes impunetured. [Placed in Le Conte's List, p. 10, with a mark of interrogration, under Amara septentrionalis, Lec., and with the note that the name has been previously employed for another species.]

[51] 73. Patrobus Amenicasus, De Jean.-Three specimens taken in Lat. $54^{\circ}$. Iength of body $5 \frac{3}{4}$ lines.

[Preriowisly deseribed as Feronic (Patrolus) longicollis, Say.; not uncommon in Ontario. For description vie Say's Ent. Works, ii. 466.]

[52] 74. Peryphus [Bembidum] bivaculatus, Kirby. - Length of body $3 \frac{1}{4}$ lines. Taken in iăt. $65^{\circ}$.

Body glossy, underncath black, above black-bronzed with a slight greenish tint. Head triangular, with a thick eoures neek; frontal impressions long and deep; antenue longer than the prothorax, third joint of the length of the succeeding ones; scape and palpi rufous; prothorax obcordate convex, at the base depressed, constricted and grossly punctured; dorsal c. vnnel as in Patrobus; basilar impressions single, round and decpish; elytra sightly furrowed, with the furrows punetured; the sereuth from the suture nearly obli. terated; apes nearly smooth, near which is an oblique pale spot; legs rufous with darker thighs, especially in the middle.

N. B.-When the elytra are raised from the body, they are dusky-bronzed. [The old genus Peryplizs is included by Le Conte as a group under Bembidium, Pro. Acad. N. S. Phil. 1857, p. 3.]

75. Peryphus [Bendidium] sondidus, Lïrly - - Length of body 3 lines. A single specimen taken in lat. $51^{\circ}$.

This so nearly resenbles $P$. Limaculutus, that $l$ first put it aside as an immature specimen, but further consideration isduces me to consider it as distinet. It is wholly pale rufuus, exeept the head, the prothorax and the anus: the three first joints of the antennac and the base of the fourth are also rufous: the prothorax appears rather narrower in proportion, and less distinetly punctured ai the base; the spot at the apex of the elstra is larger, and the thighs are rather slenderer. 
[53] 76. Perypius [Bembidium] scopulinus, Kirby.-Two specimens, taken in lat. $54^{\circ}$. [Previously described as B. postremum, Say, Ent. Works, ii. 561].

77. Peryphus [Bembidium] rupicola, Kirby.-Taken abundantly in Jat. $54^{\circ}$ and $65^{\circ}$. Length of body $2 \frac{1}{2}$ lines.

This little species appears to be the American representative of $P$. littoralis, which in many respects it closely resembles. It is, however, a smaller insect. The body is invariably piceous or rufo-piccous, and the head and prothorax are of the same colour, bronzed; the antenua are ferruginous, with the scape paler; the prothorax is rather shorter. [Included in Le Conte's List as a variety of B. rupestre, Dej., tetracolum, Say, Ent. Works, ii. 503].

[547 78. Perypius [Bembidium] PICIPEs, Kirby.-Length of body $2 \frac{1}{4}$ lines. Two specimens taken in lat. $65^{\circ}$.

Body black, glossy, above scarcely at all bronzed. First joint of the antennx rufo-piceous; sculptnre of the head, prothorns and elytra precisely that of the preceding species of the genus; elytra unspotted, with two punctiform impressions situated as in P. siopulinus, \&c.; legs rufo-piceous. This comes very ciose to $P$. nitidulus, but that species has no punetiform impressions, and the legs are of a different eolour.

79. Peryphus [Bembidium] concolor, Kirby--Length of body $2 \frac{1}{2}$ lines.

Body and members black, glossy, above bronzed. Scape of the antennæ piceous; prothorax less constricted behind than in P. picipes; space between the basilar impressions impunctured; clytra morc dceply furrowed with larger punctures in the furrows; the lateral furrows are not obliterated, but the apez of the elytrum is impunctured. [A species unknown to Le Conte.]

80. Perypus [Bembidiun] quadrimaculatus, Limn.-Two specimens in lat. $54^{\circ}$. [Subsequently described as B. oppositum, Say.-Ent. Works, ii. 501 ; taken in Canada.]

[55] 81. Peryphus [Bembidium] nitinus, Kirby. - Plate i. fig. 7. Length of body $3 \frac{1}{5}$ lines. Two specimens, taken lat. $54^{\circ}$.

Body linear-oblong, subdepressed, very glossy, underneath black, above black-bronzed. Head triangular; frontal impressions long and rather eurvilinear; scape of the antennse rufous underncath; prothorax nearly square, and level with curving sides; dorsal channel nearly obsolete; basilar impressions double, the inner one round and rather deep, the other very slight, with a little rilge between it and the margin; anterior and posterior margin nearly straight; elytra with sides nearly parallel as well as the apex impunetured; a quintuple series of punctures adjoins the suture, which extends very little beyond the half of the elytrum, with traces of slight furrows beyond it. [Taken in Canada; a specimen in our collection from Mr. B. Billings, Ottawa, 
Ontario; at Fort Simpson, Mackenzie River, by Mr. Kennicott; and in the Platte River Valley, by Dr. Le Conte].

[56] 82. TACHYTA PICIPES, Kirby.-Plate viii. fig. 6. Iuength of body $1 \frac{1}{3}$ lines. Four specimens, taken in lat. $54^{\circ}$.

Body black, glossy. Frontal impressions rather oblique; eyes less prominent than usual in the tribe; prothorax broader than long, subobcordate; basilar impressions, which are single, aud dorsal channel, rather deep; elytra with three obsolete impunctured furrows next the suture, which do not reach the apex. Apex rounded; legs piceous. [Previously described as, Tachys nanus, Schaum, and Bemb. inornatum, Say.-Ent. Works, ii. 502 ; taken in Canada.]

[57] 83. Notapius [Bembidium] nigripes, Kirly.-Length of body 2 lines. Three specimens, taken in lat. $54^{\circ}$.

Body black, glossy; above bronzed with a greenish tint; the whole upper surface, under a powerful magnifier, appears covered with innumerable granules, which are much more distinctly seen in this fumily than in the Peryphida. Seape of the antenna, which are longer than the prothorax, rufo-piceous; frontal impressions parallel; the punctiform impression adjoining the eyes on their inner side has a central elevation : prothorax short, with a deep dorsal channel; basilar impressions double, with a little ridge between the external one and the margin: elytra furrowed; furrows punetured for about two-thirds of their length; the first and second reach the apex, where they are confluent; the third and fourth stop a littis short of the apex, and are also confluent, as are the fifth and sixth, which are still shorter, and tenninate in a little furrow sommon to both; the serenth and eighth reach the apex, where they likewise unitc; two punctiform impressions, in the usual situation, adjoin the third furrow; at the base of the elytrum, in the interstice between the fifth and sixth furrows, is a longitudinal lurid streak, then follows an abbreviated and articulate band of the same colour, consisting of four streaks, those near the lateral margin being much the longest; in the interstices between the second and third furrows are two such little streaks; near the apex is likewise auother band, both articulated and undulated, consisting of seven spots, the marginal one beiug rather the longest; the tips of the elytra are likewise lurid.

$N$. nigripes is related to $N$. ustulatus, and appears to be its American representative; it differs from it in having black legs, and the lurid markings of the elytra are different: it comes nearest to Gyllenhal's Variety C. [Vide Pro. Acad. N. S. Phil., July 1860, p. 316.]

[58] 84. Notaphus [Bembidium] intermedius, Kirby. - Length of body $1 \frac{1}{3}$ lines. A single specimen, taken in lat. $54^{\circ}$. 
Very nearly related to $N$. nigripes, but the head and prothorax are greener; antennae as long as the prothorax ; the palpi are rufous, with the penultimate joint rather dusky; elytra bronzed-lurid, with a round blark spot near the base, a larger near the apex, and an angular band of the same colour between them; the legs are dull rufous. The sculpture of the elyira is ncarly the same as in that species, but the fifth furrow, by a turn outward, almost intercepts the sixth and seventh, and then ruas to the apex of the elytrum; the furrows themselves are black. lines.

85. NotapHus [Bfmbidiun] variegates, hirby. - Length of body $1 \frac{3}{4}$

This also is related to $N$. nigripes, but is quite distinct. The head and prothorax are without any green tint; the antennze are not longer than the prothorax; the prothorax is proportionally not so wide before and narrower behind : elytra scarcely at all bronzed; lurid with a large blackish cloud or spot near the base, another near the apes, and an intermediate black angular band; the furrows of the elytra, especially the esternal ones, do not reach the apex, or at least are obliterated; they are punctured the whole of their apparent length; instead of two, there are three punctiform impressions; the legs are rufo-piceous. [This name is preoccupied by Say's species; Le Conte considers Kirby's species syno "tmous with $B$. versicolor Lec.]

[59] 86. Bembidius IMPi suM, Gyll. - Iength of body $2 \frac{1}{3}$ lines. Taken frequently in lat. $54^{\circ}$ and $65^{\circ}$, and in the journey from New York to Cumberland House. On the sandy shores of Iake Winnipeg, in the spring of 1825 (Mr. Drummond). In Canada (Pr. Bigsby).

[60] Body underneath green, bronzed, very glussy; above bronzed, gloss much obscured, occasioned by an intinity of most minute reticulations, visible only under a good magnificr, which give it a granulated appearance; frontal impressions and ocellated punctures as in Notaphus; eyes very large and prominent; palpi bronzed, with the second joint obscurely rufous; antennæe longer than the prothorax, with the scape and the base of the second and third joints rufous ; prothorax short, depressed both at the base and apex, the depressed part being wrinkled longitudinally; dorsal channel and basilar impressions rather deep; in the latter are tro little furrows; in the elytra, a little bejond the midule, in the interstice between the second and third furrows, are two quadrangular; oblong; slightly dopressed spaces, of a somewhat golden lustre, and marked at the anterior end with a punctiform impression; immediately before, between, and after the depressed spaces, is a levigated and rather clevated one of the same shape; the furrows of the elytra are arranged nearly in the same way as those of Notaphus intermedius, above described: the legs are rufous, with the thighs bronzed at the apex. [Taken in Canada.] 


\section{Gats Orstrmes, Singr.}

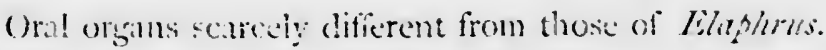

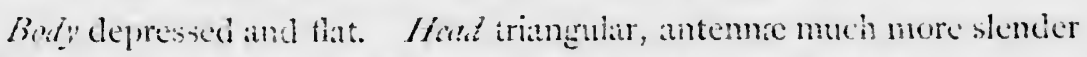

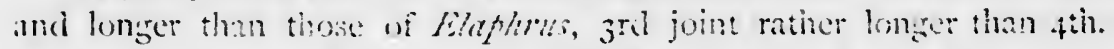

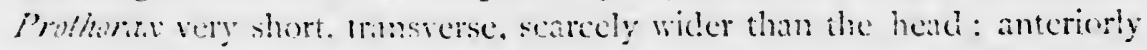

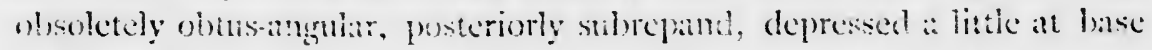
and ajex : chamelled, bat without basibr imprestons; sides grbbous :

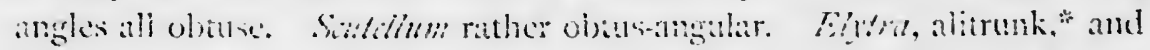
abdomen rery mucis dilated, neary twice the widts of the prothoras, whont iurrows, with several rows of obsolete mammillated inpressions.

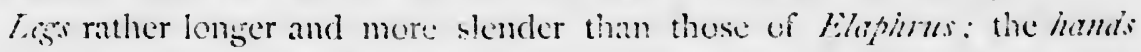
of the male have the first fuar joints a litte dibicd and furnished underne:th with a brosh.

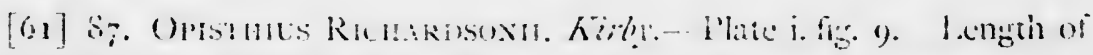

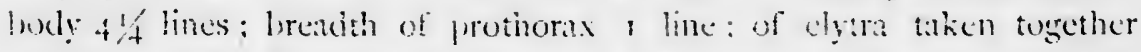
$2 \%$ lines. Mr. Drumonl. from my description of this carious insect, thinks it was taken in May, r\$25, on an istand of latie Wimmiper. freyquenting moist, mokdy places from which the water lad sinrumk.

body with the flos: obscured; mherneath black, somewhat hairy: above, a little bronace. Intenare nearly half the length of the body, first fose joints greenish-bronad, the rest deep hace frent with a slight impression betreen the antenne and a fow scattered short whitish hairs: frothorax very short, more bronad, anmsersely very minutely wrinkled : chtra with three rows of colong, grenish, very slight impressions, each with a central oblong clevation. with another levigated one between each ; adjoining the lateral margin is a futrth serics of greenish-broned more numerous impressions without any central or intermediate elevations; thighs green-lronzel, libic obsurely rulous, tarsi black. legs hairy.-[Taken at Jort Simpon, Maclienzie River, hy Mr. Robert Kennicott.]

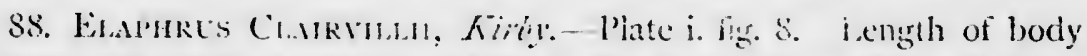

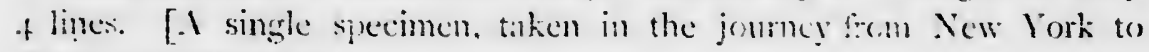
Cumberiand-bouse.]

[02] body glossy; molementin sreen-brenacel: abse back, slightly bronzed, covered with minute, scattered, sileded punctures. Mamblibles and palpi piceous; antenna black, with the three first joints dark blue; front with an elevation between the eyes, rather deeply impressed in the centre: prothoritx longer than wide, uneven, with two large discoidal

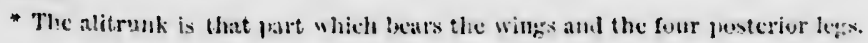


clevations separated by a dorsal channel, each with a central impression : a single basilar impression at the posterior angles tinted with blue : elytra with four irregular rows, containing in alt twenty-one slight circular impressions punctured, and tinted with blue, each, except the marginal ones surrounded by an elevated ring, and placed in a wider impression; between each of these impressions in the two frst rows is an elevated and levigated space ; thighs glossy-green, the posterior pair rufus at the base; tibire and tarsi pictous.

I an doubtful whether this species may not be Mr. Say's E. rifarius, but it is not the real one, from which, and E. uliginosus, it is distinguished by being much less thickly dusted with green-gold glittering punctures. which gives it a blacker hue. The impression also in the elevated space between the eyes is much deeper. The blue-tinctured impressions of the elytra are also more distinct, and surrounded by a more elevated ring. [Taken on the Island of 'Toronto, ly. Mr. Colyer.-Can. Fimrmal, i856, p. 33.]

89. Elaphrus intermintes, Kirlly.-1, ength of body + lines. [Taken by Dr. Bigsby in Canadia.]

'This species resembles li. cuprous, but it is quite distinct. The looly' is more thickly and minutely punctured on the whole upper surface; underneath it is of a fine bronzed-green; ahove it is blacker and less brilliant; the head is greenish; the middle space between the eyes is less elevated than in that species, and wrinkled longitudinally without any impression : the impressions on the discoidal elevations of the prothorax are fainter; the elytra, like the other species, have a quadruple series of impressions, but they are broader, more slight, without any elevated ring, are more minutely punctured, have a slight elevation in the centre, and are of the same colour with the rest of the elytrum; the marginal series is nearly obsolete; just before the middle, adjoining the suture, is a quadrangular elevation which unites with that of the other elytrum: the thighs are green, rufous at the base, tibia rufous, tarsi piceons. [Taken in Canarla.]

[63] 90. Ejaphrus onscurior, Kirly.-length of body $3 \frac{1}{4}$ lines. $\Lambda$ single specimen, taken in Lat. $65^{\circ}$.

This species is more strongly marked than the majority of the Elaphri. On the underside the head and trunk are copper, with a slight tint of green : the abdomen of a dusky purplish copper; above it is copper-coloured; the head, with the exception of the upper-lip, is very thickly and confluently punctured, with a levigated but scarcely elevated space between the eyes; 
the four first joints of the antenna are cupreous ; prothorax not wider than the head, confluently and thickly punctured : discoidal elevations not conspicuous nor impressed ; clytra not glossy, punctured with scattered punctures, marked by a quadruple series of very slight impressions, some nearly olssolete, most of them marked out by a very slight elevated ring and a circle of punctures, three levigated quadrangular spacer near the suture. and arranged in a line parallel with it, and a fourth triangular one removed from it, near the apex; the disk of the elytra is fainti; surple: legrs bronted.

9r. Nomophars agcarkes, Linn.--One specimen taken. [An erroneous determination, according to I)r. LeConte, who considers it to be: $N$. semistriatus-Say. For description, which very closely corresponds with Kirly's, ride Siy's Fint. Works, ii. 497.]

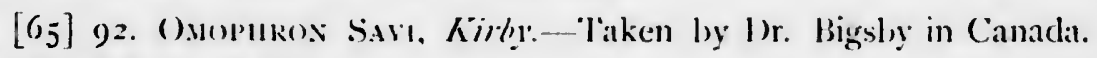
length of body $31 / 2$ lines.

'This species seems intermediate between $O$. limbatum and $O$. lithalum. From the former it differs in having a much fainter tint of green on the darker parts of the body, in its black prothorax with silvery sides as well as margin; from the latter, in having the lateral furrows as deep and distinctly punctured as those of the disk; and, instead of two reddish spots near the base of the elytra, having two angulato-undulated bands, one near thic base and the other beyond the middle, and the tips testaceous ; all connected by the margin of the same colour. It seems to have escaped the describers of $O$. limbatum that the upper-lip and lateral margin of the prothorax and elytra are likewise silvery, though not so conspicuously as in O. labiatum and Sayi.

The sculpture of the elytra in this genus, as well as in Calosoma, differs from that of the other terrestrial predaceous beetles in having more than nine furrows, which appears to be the typical number in the section.[Synonymous with O. Amcriarmum, Dej. ; taken in many parts of Canada.]

$$
\text { [Ent of the CARAmur..] }
$$

['This family, usually regarded as a sub-fimily of the Dytiscidle, is restricted by LeConte to the genera Haliplus and Cucmidotus; but Kirby, as will be observed, includes it in the genera /lydroporus and Laccophilus.] 


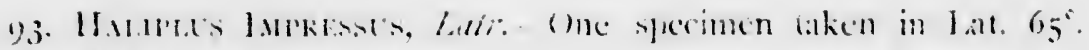
i.cingth of body $1 \%$ lines, ne:sly.

[66.] Body, reddish-yellow; heid punctured, dusky behind ; prothorix yellow, depressed in the middle posturiorly, with a transterse curved series of punctures in the clepression : anteriorly there are five or six black dot: arranged transwersely; at the base, between the central point and the margin on each sicke, an ollicue litile furrow, but not casily discorcrable. is imjersed : elytrin pale-yellow, with a cinereons tint, nine rows of hlacts panctures on each, those mear the haterst margin being the faintest : anteriorly, in the interstices of the rows, there are also a few black punctures; the apex of the elytra is oblipue, leminating in an ac ute point: the lamine that corer the posterior legs are punctured. [Kirly is doubtul respecting the identity of this specimen with Latreille's species, as, though the latters description agrees with it, his figure loes not, for it represemts the elytra with eight black spots, which are not to be found in $\mathrm{K}$. Improses.

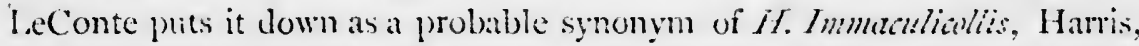
a species taken in Canadia, and regards its identification with Latreille's species as erronconts.]

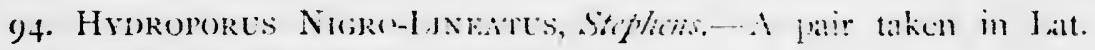
$65^{\circ}$. l.ength of body $2 ! 2$ in.--2 $3 / 4$ line:s.

body lurid-ycllow, sonewlat glossy, mintely and thichly pmetured: antenae dusky at the tip); puthoras with a minute islack rhomboidal spot in the disk, which is marked with a punctiform! inpression : anteriorly it hats a transwerse series of punctures larger than those of the rest of its surface; elytra most numerously and mintely punctured ; the suture and four longitudinal stripes not reaching the apex, nor the first and third the base, all black ; the fourth, or outermost, is distant from the margin and interrupted; the alitunk and abdomen are black. In the female, which is less glossy, the externa! stripe is continucus, and only the second reaches the base; and in the male, the prothorar is more conspicnously punctured. and the anterior series of punctures is wanting.

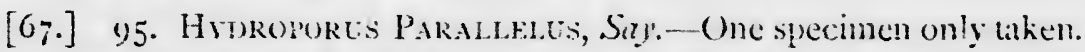
[I'reviously described ats $/ T$. Caftaciphinm, Say, and subsequently as $/ /$.

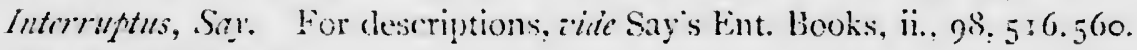
Taken in Canada.]

96. Hrdroports L.Evts, Kirly.--length of hody 2 lines. (He specimen only taken.

Very like the preceding species, but smaller; it differs principally in 
being perfectly smooth and without punctures, even when examined under a powerful magnifier. The head has two larger vertical, lurid-yellow spots. and there is a triangle of the same colour between the eyes, which at its base is dilated, and occupies the nose and mouth : the prothorax is lurid. yellow, with two oblong oblique dusky spots ieyond the mildle; towards the base is an obtus-angular transverse impression, and on each side, at it little distance from the margin, is an oblong punctiform impression: in the elytra are six distinct narrow black stripes, none of which are confluent except at the apex: at the side, but at some distance from the iateral margin, are three black spots placed in a line. or a stripe wider than the others twice interrupted: the legs are sestaceous, with the posterior tibite black at the tip. [Placel, with a mark of interrogation, als a sinonym of $H$. Ducdecimlineatus, l.ec., in I.eConte's list, p. 16.

[68.] 97. Hrdroports Pratrs. Kirby.-Length of body 2 ? lines. A single specimen taken in $\mathrm{I}$ at. $5 t$.

Body, dark piceous, without gloss ; rovered, especially abose, with an infinity of punctures. Head, obscurely ferruginous, dusky hehind, with a paler quadrangular spot extending to the mouth, between the eyes : antenna ferruginous : prothorax, with its anterior half, ferruginous, marked with a discoidal punctiform impression or little furrow: elytra, with four posteriorly abbreviated punctured furrows, very difficult to be discerned, and only by looking on one side from behind : forebreast and legs iemuginous : alitrunk and abdomen black.

98. Hydroport's Similis, Kirty.-Length of body 218 lines. Taken with the preceding species?

I at first regarded this as the other sex of $H$. Piatus, but upon inspecting their tarsi I found they were both males. This species is smaller, more glossy; the parts that in that are dark ferruginous, in this are much paler; the punctures on the upper surface are less numerous and larger, especially those of the basilar half of the elytra, and the four furrows, particularly the three dorsal ones, are deeper and more distinct ; the disk of the prothorax also is transversely levigated and impunctured. Both these insects come very near to $H$. Picipes, but that species has not the discoidal impression in the prothorax ; and its elytra are dark testaceous, striped with black.

N.B. - All the above divisions belong to Mr. Stephens' second division of the family, with the sides of the prothorax rounded. $[H$. Similis has been taken in Canada.]

[69.] 99. Laccophilus Biguttatus, Kirby. - Length of body 2 lines. One specimen taken. 
Body, very smooth, glossy. Heal, dirty-ycllow ; falpi, and antenna dusky at the tip): manitrunk (tixe manitrunk is that part of the trunk that hears the anins or fore-legs: it includes the prothorax and antepectus), dirty vellow ; clytra, embrowned cincreous, with a line of punctures, as in the other species, adjacent to the suture, and a pale yellow, indistinet, oblong. anterior, marginal spot: less, lirty yollow ; posterior tarsi, dusky; alitrunk and aldomen, nigro-piceons; ajex of the segments of the latter reddish. yollow. 'I his species is smaller than L. minuths, which it resembles, and the colour of the elytia and indersile of the body dificrs. [Inserted as a jrobable synonym of $L$. fasiuturus, Aubi, in LeCente's list; in Melsheimer's Cataloguc it is recorded as synonynous with $C$. frowimus (Say) and L. Ameriannis (Aubi).]

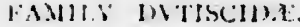

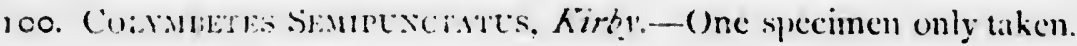
length of body $3 \frac{1 / 4}{4}$ lines.

Body oblong, glossy, very black, abose very slightly bronzed; under a powerful magnifier the whole upper surface is most minutely reticulated, and the under covered with longitudinal scratches. Head with a pair of vertical red crescents placed transversely, and scarcely visible cxcept when the sun shines; upper-lip, palpi, and antennae ferruginous: mandibles black; prothorax, anteriorly with a continuous transverse marginal scries of plinctures, posteriorly with one widely interrupted in the middle, and in the disk with a minute furrow: elytra with a triple clorsal series of punctures not regularly or singly arranged, with other scattered punctures interjacent, especially towards the apes; on the side the punctures, which are not numerous, are se:uttered without order; in the sutural series the punctures are distant and single; beyond the middle of each elytrum, not far from the lateral margin, is a red streak, not distinctly visible except in a strong light: the arms are piceous, and the four anterior tarsi ferruginous. [Belongs to Agrilus. Taken at (irimsby, Ont., by Mr. Pettit.]

[70.] ror. Colymbetes (Agabus) Bicolok, Kirby:-Length of body $31 / 2$ lines. A single specimen taken in Lat. $54^{\circ}$.

Body nearly elliptical, convex, smooth, glossy, and very black. Reticulations more visible in the head than in the rest of the surface; a pair of round, obscure red spots in the vertex; mouth palpi, and antennx testaccous : anterior transverse series of the prothorax with single punctures at the sides, but scattered ones in the middle; posterior series continuous, with single and rather distant punctures; elytra, externally of a pale 
unahogany colour, with a double series of punctures, not numerous nur regularly arranged, which do not reach the apex ; there are a very few scatsered punctures besides in the side : lecrs mahogany-colour.

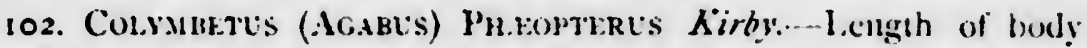
$3 / 4-31 \%$ lines. Two specimens taken in 1alt. $54^{\circ}$.

Body nearly elliptical, rather depressed, smooth, very black, glossy: Head with a pair of transverse obscure red spots in the vertex; mouth and antenna testaceous : posterior series of the prothor: $x$ thickly punctured, and discontinuous in the middle: elytra brown, a little paler at the base and side : epipleura yellow: sculpture of the elytra like that of $C$. Semisienctatus, but fewer punctures in the side: legs ferruginous : body underneath longitudinally scratched. This species appears to be the Ancrican representative of $C$ : paludiosus (Dytiscus politus Marsh), which it nearly resembles, but the anterior part of the front is black, and not yellow as in that species; and the prothorax is wholly black, without a brond rufous margin. [Placed with a mark of interrugation as a synonym of $A_{s}$ rabus ebliteratus L.ec., in I.cConte's I.ist, [1. 17.]

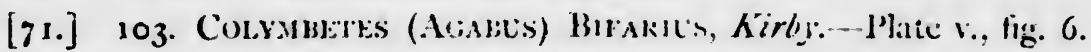
length of body $3 \frac{3}{4}$ lines. A single specimen taken in Lat. $5.4^{\circ}$.

Body oval, smooth. black, less glussy. Head with a pair of vertical red crescents: nouth, antenna and palpi ferruginuus: maxillary palpi with tise last joint black: prothorax longitudinally acuducted, with the bead of the lateral margin rufous: elytra at the base longitudinally, at the apex transversely, acuducted: fore-breast and legrs piceo-rufous.

104. Colymbetr:s Rriculates, Kirlỵ-- length of body $3 \frac{1}{4}$ lines. 'Three specimens taken in Lat. $65^{\circ}$.

Body oblong, black, gloss obscured from its being covered as it were with a web of the finest net work, sculptured as if with the point of a ncedle. Head with a pair of round red vertical spots: prothorax with a yellow mesal band and lateral margin: elytra dusky-cinereous, with the side yellowish: legs ferruginous. [Not mentioned in either leConte's or Melsheimer's Catalogues.]

105. Colrmbetrs Picipks, Kirby.-length of body $4 \frac{1}{4}$ lines. Two specimens taken, one in Lat. $54^{\circ}$, the other in Lat. $65^{\circ}$.

[72.] Body oval, black, above slightly bronzed, not glossy, covered above and below like the preceding species with, as it were, a web of network ; but the reticulations are more minutc. Upper-lip, palpi and antennæ ferruginous; a pair of oval, minute, obscure red spots mark the vertex : 
prothoras, with the anterior transverse series of punctures double in the middle, the posterior one not easily discernible, discontinuous in the middle: there appear no rows of punctures on the elytra; but a few scattered ones may be discrvered: the four anterior legs are piceous. This species approaches $C$. chulitmatus, but it is longer, less glossy, the reticulations of the surface are more distinct, no rows of punctures are discernible, as in that on the elytra, which, as well as the prothorax, are all of one colour; and the posterior legs are black. It seems still nearer $C$. ater, but it is much smaller, less convex, and has no fenestrate" spot on the elytra. [Taken in Canadi..]

106. Colymbetes Assmuls, Kirly,-Length of hody $53 / 4$ lines. laken in Nova Scotia by Dr. MacCulloch.

Body rather depressed, between oblong and obovate, smooth, rather glossy, black, covered above with an infinity of very minute reticulations. Head dirty-yellow: vertex black, with a pair of confluent transverse reddish spots; prothorax dirty-yellow, rather dusky in the disk, transverse punctures nearly obliterated: elytra of the same colour as the prothorax, but sprinkled with innumerable black dots, which, however, do not exterd to the base and sides; a row of more distant and larger dots adjoins the suture: the fore-breast, the base and apex of the other ventral segments of the abdomen are dirty yellow; the legs are of the same colour, but the arms are shorter than usual, and piceous; the dilated posterior coxæ are sculptured with branching rugosities. This species represents $C$. notatus, which it is very like, but the elytra are wider towards the apex, which gives the insect an obovate shape; the black dots of the elytra are more numerous and minute; the prothorax is without spots; and the arms, or fore-legs, are shorter and of a different colour. [Included under Agabus, in Melsheimer's Catalogue.]

[73] 107. Colymbetes triseriatus, Kirby. - Length of body $73 / 4$ lines. A single specimen taken. I have a specimen also from New England, taken by Professor Peck.

Body elliptical, rather depressed, underneath black, and covered with an infinity of branching or confluent wrinkles, as if scratched by a pin or needle. Head black, anteriorly testaceous; between the eyes is a pair of transverse red spots; antennæ and palpi testajeous, dusky at the : tips : prothorax testaceous, with an abbreviated, sub-bilobed, discoidal. band; variously acuducted so as somewhat to resemble net-work: sçutellum. ferruginous, black at the base, very minutely and confluently punctured : 
elytra dusky, which colour, for they are really lurid or dirty yellow, is produced by an infinity of transwerse black lines or furrows, but which at the lateral margin lose their blackness : besides these there arc three rows of punctures arranged longitudinally but not regularly, the first adjoining the suture, and the two others being discoidal; between the outer one and the margin, especially near the apex, are some scattered punctures; the epipleura, and sides of the fore-breast. are yellow: leiss testaccous; thighs and tilbia punclured.

This species is intermediate between $C:$ siriotus and $C$ : doluhratus. with the former it agrees in the majority of its characters, particularly in the longitudinal row's of punctures, except that its sutural one is more perfect; and with the latter in the prothoracic band and the color of the legs. The transverse furrows of the elytra are rather deeper than those of the first-mentioned species, and not so cleep as those of the last.

These insects, adding $C:$ fuscus, may perhaps be regarded as forming a subgenus, whose common character is the peculiar sculpture of the elytra. [Synonymous with $C$ : sithplilis Harris; a species taken in (anada.]

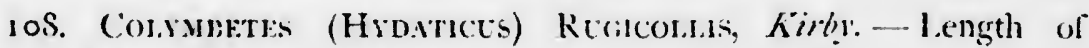
body 6 lines. Taken in Nova Scotia by Dr. MacCulloch.

[74.] Body rather obovate and depressed; underreath rufous cloudy with dusky. Head subrufous, dusky behind; antenna and palpi yel lowish, dusky at the tip; prothorax with the posterior angle acuminate, subrufous, dusky in the disk, posteriorly scratched longitudinally as if by a pin : elytra pale-yellow, thickly and minutely reticulated or vermiculated with black; lateral margin yellow; unspotted: epileura yellow ; prosternum depressed. This species appears to represent C. H. irroratus.

109. Colsumetis (Honatices) MacCulochu, Kirby--Length of body $53 / 4$ lines. Several taken in Nova Scotia by Dr. MacCulloch.

Body obovate, depressed, glossy; underneath hlack, confluently punctured and wrinkled. Head posteriorly minutely punctured, black : nose, mouth, and its organs, and a band between the eyes pale yellow; antennæ pale with the joints above dusky at the tip: prothorax punctured, pale yellow, with a discoidal band, dilated at each extremity and surrounded by a black margin of the same colour : elytra black, sprinkled with innumerable pale-yellow dots; near to the apex is a pale, angular, undulated band, and beyond it a round white spot; the margin of the clytrum is paler, than the rest: the three intermediate ventral segments of the abdomen have cach a pair of roundish pale spots, one on each side; 
the four anterior legs are pale yelow. [1'revicusly described as dibius Méliatus Say-Ent. Works ii. 508.]

1 10. Dytiscus oolicnuku, Kirly:-Length of body: male. I inch and 4 lines; female. $I$ inch and 5 lines. A pair were taken by the Esquimaux Ooligbuk in the Great Bear Lake River. [75.] As this species was taken by the useful, worthy and honest Esquimaux Ooligbuk, 1 trist I may be excused for giving to it his name. [Previously described as Ditiscus conflucns by Say-for description ride Say's Ent. Works ii. p. 554.- He gives the State of Maine as its habitat; it was taken on the north shore of Lake Superior by Agassiz's Expedition, and is now included in the list of Cariadian Coleoptera. lts range, it will be observed, is thus a very wide one.]

[76.] 111. Dytisces Harrisu Kirly--Length of the body 1 inch and 8 lines. One specimen taken in the journey from New York to Cumberland House.

Body black, underneath banded and clouded with pale chestnut. Head smooth; nose, upperlip, and palpi, reddish-yellow: the latter with the last joint dusky; between the eyes is an obscure, roundish, red spot; prothcrax smooth, except an anterior transverse series of punctures which does not reach the sides; as in the preceding species it is surrounded by a broad reddish-yellow margin: sculpture of the elytra like that of D. Ooligbukii, etc., but not so grossly punctured at the apex; side reddish-yellow, the yellow stripe terminating in a fork or two branches, the upper one not consisting of dots as in D. Marginalis, etc., but entire and toothed: a reddish-yellow arch marks the dilated posterior coxæ, and the base of the abdomen is of the same colour; arms and thighs, pale chestnut. tibia and tarsi of the four posteric: legs black: the lobes of the metasternum are remarkably obtuse. I have named this insect after a very eminent Ainerican Entomologist, Dr. T. W. Harris, who well merits such distinction. [One of our commonest Canadian species of large water-beetles. North shore of Lake Superior (Agassiz). A specimen in my cabinet flew in at an open window attracted by light, July 1,1864 .

[77.] 11 2. Dytrscus (Leionotus) Franklinin Kirby. Plate ii. fig. 1. -Length of body $x$ inch and 4 lines. A pair taken in Lat. $65^{\circ}$.

Male. Body oblong-ovate, glossy as if covered with varnish; underneath black spotted and banded with pale chestnut; above dark olive, in ccrtain lights of a beautiful olive-green. Head with a wery few minute, scarcely discernible, punctures; antenna chestnut; mandibles and palpi 
black; nose, upperlip, margins of the prothorax, and side of the elytra, dusky yellow: prothorax distinctly channelled, surrounded within the margin with an irregular series of punctures, interrupted at all the angles, and in the middle anteriorly and posteriorly :' elytra sculptured, as in the two preceding species, except that there are several very obsolete rows of flat granules, scarcely discernible, between the suture and the first row of punctures; and there is no yellow oblipue band or gleam near the apex: legs black, with the arms and intermediate thighs dusky cr dusky lurid; the lobes of the metasternum very actite, nore than usually diverging; incurved a little at the apex.

Fenele. Head more visibly, though still very minutely, punctured; prothorax minutely punctured; elytro. more coarsely punctured at the apex; legs dusky lurid, posterior tibix darker, tarsi black : scapulars, and parapleura grossly punctured; angle of the mesostethium wrinkled; posterior coxa lightly, but not thickly, punctured; lobes of the metasternum very acute, not incurved on the apex. [Considered by leconte to be al variety of D. Conflu'ins say.]

FAMIIX (KRINID.

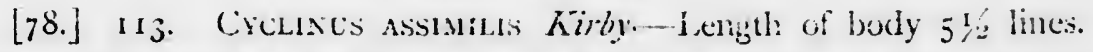
Two specimens taken in lat $54^{\circ}$, [79.] Body de]ressed, clocvate; malerneath glossy, black, slightly bronzed ; upperlip ininutely punctured; front wrinkled between the eyes; nose impressed on carh side: prothorax anteriorly on each side with a transverse serics of punctures parallel with the margin, and with a slight discoidal transverse impression; at the base obtusangular and somewhat wavy: elytra with nine very slightly impressed furrows, the interstices of which are minutely punctured; at the apex the elytra are wavy; epipleura black-bronzed: legs and anus testaceous. This species approaches very near to Gyrinus Americamus belonging to the same genus, of which $I$ at first regarded it as merely a variety, but upon comparing it with with the specimen preserved in the Linnean cabinet, it appears clearly distinct. 'This species is smaller, bronzed above, and the interstices of the furrow's are without punctures. [Regarded by LeConte as synonymous with Dineutes (Gyrimus) Ameriatmus Linn. This species is common in Canada. I.eConte (Pro. Acad. Nat. Sci., Philada., Dec. 1868, p. 367), says that it is "our most abundant species, usually known as apple buy ; extends from Iake Superior to "lexas, and from Maine to Kansas."]

114. Gyrinus impressicol.Lis Kirby:-- Length of body 4 lines. Taken in Canada by Dr. Bigsby. 
liody glossy, black underneath, above blue-black. Head a little bronzed ; nose transversely impressed, wrinkled ; frontal impressions large and deep : prothor $x$ with a deep anterior transverse impression, reaching ncarly from side to side, in the centre of which is also a deep punctiform impression, and behind it on each side two others, but wrinkled and more shallow: un each side also is a large gibbosity or boss : clytra nearly oblong, with eleven rows of shining bronzed punctures; at their apex the punctures are scattered, the margins also are bronzed; epipleura ilack; the tip of the clytra is very obtuse and almost truncated: legr rufous. This species is rery near $(i$. marimus, lunt it is much larger. and is sufficienty distinguished from it by the deep furrow or channel that runs guite across the prothorax, its more prominent bosses, and its mpressions. In (i. anrizizs, also, the punctures at the tip of the elytra are not scattered, hut mark out a crescent-shaped atea: and the apex itself is not so obtuse. [Referred to $(i$. borcalis Aube. by White. (Brit. Musenm (att. 45). but probably incorrectly.]

[80.] 115. (ivkrises textes Leach. - Length of body 2: lines. Taken in Camadia by Dr. Bigsby. Very like the preceding species, but much smaller, the transwerse impression of the nose and the frontal impressions are not so deep : that of the prothorax is not so conspicuous. and there are no lateral hosses ; the elytra are much narrower at the apes. where, as in $G$. Marinus, a crescent is marked sut by punctures.

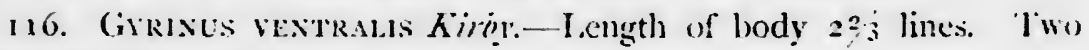
specimens taken in lat. $5 t^{2}$.

Nearly related to $G$. aceiss, but the whole prone suriace of the body, the epipleura of the elytra, and the legs, are ferruginous; in which particulars it resembles $G$. lineatus; it is, however, much smaller than that species, the punctures in the rows are more conspicuous, and the elytra have no bronzed stripes. ["A beautiful species, easily known by its larger size and more brilliant iridescent surface; in one specimen the under surface is nearly black."-LeConte, lic: cit. p. 368 . Taken in Canada by Mr. Pettit at Grimsby, Ont.; also on north shore of Iake Superior by Agassiz's Expedition. New York to L. Superior (LeConte).]

[Sr.] 117. Civkixis axalss Kirby.-- Length of lody 3 lines. One specimen taken in lat. $54^{\circ}$.

Near the preceding, but larger, punctures of the rows larger: breist bones black ; mouth, sides of the forebreast, inus, and legs, rufous ; the remainder of the underside of the body, piceous : side-covers bronzed with a piceous tint. [Not G. analis Say.-Kint. Works ii. 520.] 


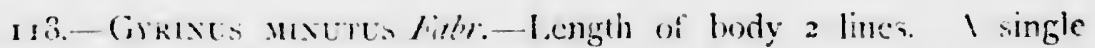
specinen taken in I.at. $65^{\circ}$.

Variety Ii. Body above bite black, with the sides, particularly of the prothorax and eiytra, bronzed; underncath piceous, with the lolues of the mcialsiernum, anus, and legs, rufous : eppipleura rufo-piceous. In other respect; it precisely resembles the luropean specimens. [I Iidt: I.cConte, Pro. Acad. N. S., Phila., Dec. 1568,1$)+\cdots 370$ and 372.$]$.

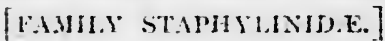

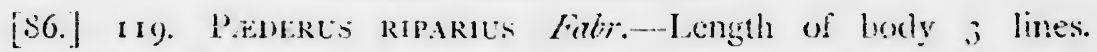
suveral taken in Lat. $5 t^{\circ}$.

Head, breast, two last joints of abciomen, base of the tibia and apex of the thighs, black: prothorax, legs, and four first segments of the aldomen testaceous: elytra dark blue : antenna dusky. [Probably an crroncous determination for $P$. Iittorarius, Grav.]

120. lathromem pexcricolse, hirly.-Iength of body 5 lines. 1 single specimen taken in lat. $54^{\circ}$.

[S;.] Body black, rather glossy, hairy except the prothorax. Head obovate, minuiely and thickly punctured; mandibles, palpi, and what

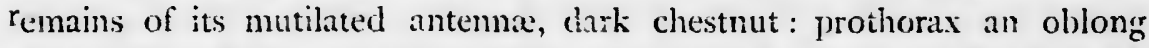
square with all the angles rounded; punctured. but not wery thickly, with scarcely any smooth longitudinal space : elytra longer thai the prothorax, thickly punctured, of a dark chestnut : legs maghogany, cubit armed wit's a short wide tooth or prominence on the inmer side at the base, the four first joints of the hand are dilated, indicating probably that the specimen is a make. This appears to be the representative of $L$. dentalum, F, which it nearly resembles, but the elytra are considerably longer, the colour of the legs is darker, and the humerus, or anterior thigh. is proportionally smaller and has no tooth. [Taken in Canada.]

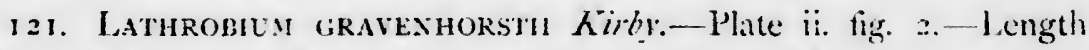
of body $4 / 2$ lines. Two specimen: taken in Lat. 54 ".

This species a good deal resembles the preceding, but the palpi, mouth, scape of the antenne, and legs, are testaceous, the remainder of the antennæ is darker ; mandibles chestnut. Head oblong: anterior angles of the prothorax scarcely rounded: a distinct intermediate longitudinal smooth spice adjoining which is a scries of "-unctures strikingly distinguishing s species from l. puncticille, the sides of the prothorax are covered with scattered punctures: the tip of the segments of the abdomen, ventral as well as dorsal, is testaceous. [Synonymous with Cryptolium fallipes (Grav.-a species taken in Canada.] 
122. IATHROBILM [CRYPTOBICN] EICOLOR Grati--Length of body $42 / 3$ lines. Taken in Canada by 1)r. Bigsby.

[88.] Body testaccous, hairy. Head oblong, wider than the prothorax, black, thickly punctured ; mandibles and other oral organs duskyrufous; antenne nearly as long as the prothorax, of the same color but paler at the base and apex: prothorax punctured with a smooth longitudinal intermediate spacc: clytra thickly punctured: abdomen black, antss testatceous. Gravenhorst describes Knoch's specimen, which also canc from North America, as having dark chestnut thorax, elytra and anus : in the specimen here described they are of the same color with the legs. The difference, as they agree in other respects, is probably accrdental. [Common in Ontario.]

123. Grrohypnus assimilis Kiribl--length of lody 9 lines. Two specimens taken in Lat. $54^{\circ}$.

This species approaches very near to 6 . vihracus, but is more slender in proportion to its length. Body black and glossy. Head rather larger than the thorax, behind the eyes are some rather large scattered punctures; antenna and palpi rufous; neck rufo-piceous; prothorax piceous, with a triple series of punctures on each side leaving a discoidal smooth space; the dorsil ones consist of seven or eight punctures, and the intermediate one:s are really a continuation of the dorsal, since by the intervention of a puncture or two both are mited so as to form in figure resembling a bishop's crosicr; the lateral series consists of a very few points, not calsily seen ; ncar the anterior angle the elytra are scarcely longer than the prothorax, punctured, with some of the punctures arranged in rows and others scattered; from the humeral to the inner apical angle, they are internally yellowish-red, and externally blackish: legs yellowish-red. [Previously described by Say--Ent. Works ii. 567-as Xantholinus cophahus. Taken in Ontario.]

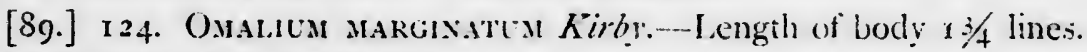
One specimen taken in 1 at. $65^{\circ}$.

Body piceous, glossy, naked, rather grossiy punctured. Head narrower than the prothorax; eyes prominent; antenna rather longer than the head and thorax, dusky-rufous: prothorax rather wider than long, lateral margin somewhat dilated; near it, and partly in it, is a deep) punctiform impression, and above the sentellum another ousolete one: elytra soinething wider than the prothorax, and nearly as long as. the abdomen, paler at their apex : legs dusky-rufous. 'This species is related to $O$. tectum, but it is more grossly punctured, the lateral margin 
of the prothorax is much more dilated, and the punctiorm impressions more distinct. [Say has described a species, taken on Long's Expedition in Missouri, under the same name. It is doubtful whether Kirby's snecies is identical or not.]

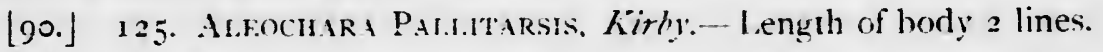
Locality unknown.

The species of this genus of minute bratlichita are so extremely numerous, nearly 200 having been discovered in Britain alone, and so difficuit to discriminate, that it is not with great confidence that I give this as a nondescript. I have many undescribed species in my cabinet that come very near it, but I cannot find one that altogether agrees with it.

Body black, gloss deadened by short inconspicuous hairs. Head rather spherical, narrower than the prothorax, rery minutely punctured; antennae shorter than the prothorax, rather robust, intermediate joints turbinate, last joint ovate, acute : prothorax sub-orbicular with the sides deffexed, rery minutely and thickly punctured : dorsal channel nearly obsolete; a large punctiform impression just above the scutellum : elytra longer and rather wider than the thorax, picecus-black, extreme tips: rufous, very minutely and thickly punctured: legs piceous-black with rufous tarsi.

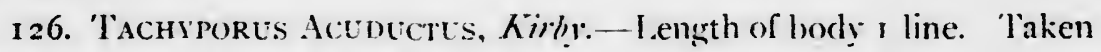
near Cumberland-house, lat. $54^{\circ}$.

[91.] Body dark-piceous, naked, smooth, glossy: Intennae and mouth testaceous : prothorax very smooth, wider than the elytra, posterior angles testaceous: elytra longer than the head and prothorax together, piceous with the external apical angle testaceous; if viewed under a good magnifyer, they appear covered, especially next the suture, with minute branching scratches, as if made by a pin or needle, intermixed with very small punctures; abdomen very short and conical, scarcely margined, piceous with the segments paler at their tip.

127. 'Tachyporus afrinis Kirby.-Length of body, $\mathbf{I}$ line. Taken with the preceding species. This species is extremely similar to $T$. acuductus, but the posterior angles of the prothorax are not testaceous ; the elytra are palish-chestnut and thickly covered with very minute punctures, without any scratches.

128. Philonthus politus Linn.--Length of body, 5 lines. Taken in Nova Scotia by Capt. Hall.

[92.] Body very black, hairy. Head orbicular, scarcely narrower 
than the prothorax, naked with the exception of a few long lateral bristle-like hairs, slightly bronzed, very glossy, smooth with a few punctures on each side in the occiput; antenna shorter than the prothorax, last joint emarginate at the tip: prothorax, rather narrowest before and transverse, rounded behind, slightly bronzed, very glossy and smooth, with a few long hairs on each side, on the disc is a double series, each consisting of four punctures, there are thres or four others in the sides: dytra bronzed, thickly punctured, with a long hair issuing from each puncture : claws of the tarsi ferruginous. [In LeC.onte's I ist. put down ats a male and synomymous with P. wintus Rossi-a species taken in Canada.]

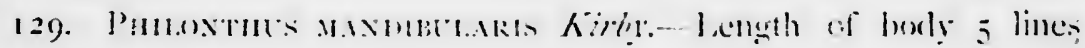
locality unkmown.

[0.3.] This species differs from the preceding chiefly in the shaye of the head, and the color of the mandibles, agreeing in the former particular with I'. politus of modern lintomologists, from which it differs, besides their colour, in having the mandibles shorter than the head; the intermediate joints of the tarsi also are rufo-piceous. [Inserted in I eConte's Jist as the female of the preceding species.]

130. Phulonthus picates Kirly:-I ength of body 3 lines. Two specimens taken in I at. $54^{\circ}$.

liody piceous, as usual in the genus somewhat hairy. Head ovate, naked, and very glossy, with a few scattered punctures on each side behind the eyes and four between them; antennx as long as the head and thorax, scape testaceous; prothorax naked and very glossy ; dorsal rows consisting of six punctures, there are five more punctures near the anterior margin arranged in two oblique rows between them and the lateral margin, and three or four other punctures are discoverable nearer the base : elytra chestnut, hairy ; tips of the abdominal segment and anus rufous: legs testaceous. [Previously described as Staphylinus (Philunthus) brunneus Grav. Taken on the north shore of Lake Superior by Agassiz's Expedition.]

13r. Philonthus Fulvipes? Graz:-Length of body about 3 lines. A single specimen taken in lat. $54^{\circ}$.

Body black, hairy, except the head and prothorax which are naked, and very glossy. Head sculptured like that of $P$. picatus; antennae with the two first joints testaceous : prothorax sculptured with regard to the dorsal series as in that species, then follow about five punctures in an irregular wavy series extending from near the base towards the apex, between which 
and the anterior angle are two placed oblingely, and sciveral besides are discoverable in the lateral and posterior margins: [94] the scutellum is black: the elytra punctured, testiccous, and hairy: the abdomen is entirely black : the legs are testaccous with the posterior cosa black; the hands are not dilated. [Taken at (irimsby, Ont., by Mr. Pettit.]

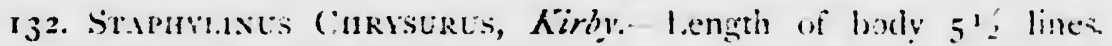
Taken in Nova Scotia by Dr. Macculloch.

Body underncath black, somewhat glosiy, sprinkled with yellow hairs. Head suborbicular, scarcely wider than the prothorax, confluently punitured, bronzed, and covered not thickly with short pale-yellow hairs, which give it a cinercous tint, with several indistinct blackish spots; rhinarium and upper-lip pale yellow; mandibles rufous at the base; stalk of the antennac testaccous, the six last joints are brown and larger than the rest, so as to form a clava : prothorax sculptured, cloathed, and coloured like the head, but more distinctly spotted and clouded with black, widest behind with a slight lateral sinus near the base: scutellum almost covered by a heart-shaped velvetty black spot: elytra, as to sculpture, cloathing. and general colour, resembling the head and prothorix, but they are differently spotted with black; in the centre of the base is an oblique oblong spet, then follows an angular interrupted band, and lastly, is a sickle-shaped band with the handle towards the lateral margin, the blade is very broad and includes an insulated cinereous spot; neither of these bands reach the suture or the lateral margin, which is tawny-yellow: the two last segments of the abdomen, especially the penultimate, are thick!y covered with short decumbent hairs, which in certain lights reflect a brilliant golden lustre; the after-breast is covered with hairs if possible still more brilliant; the legs are testaceous, but the tlighs except their tip, and a dorsal line, are black.

This specics resembles St. hybridus and mazksas, but is stuficiently distinguished by its golden tail and breast: it is one of the smallest of

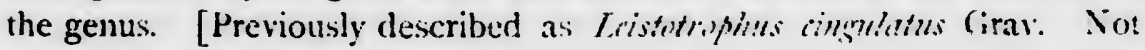
uncommon throughout Ontario.]

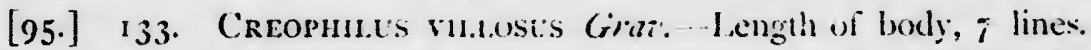
Taken in Lat. $54^{\circ}$ in Canada, also by 1)r. Bigsby, and in Nora Scotia by Capt. Hall. I have specimeas likewise, taken in Britain. [Quite common] throughout Ontario.]

'This species is extremely similar to $C$ : maxillosus, and its Anerican representative. The following circumstances principally distinguish them. 'The anterior angles of the prothorax in $C$. maviliosus are thinl! cloathed 
with shortish blait hairs; in c: rillusus, these hairs are cincrevis, longer, more numerous, and cover a larger portion of the angle; in the former, the band of the elytra is whiter and wider than in the latter: in the former also the back of the abdomen, especially the third and fourth segments, is mottled with cinereous hairs; in the latter the second and third have each a cinereous band interrupted in the middle : again the four first ventral segments in $C$. maxillosus are thickly covered with decumbent cinereous hairs, with each a lateral black spot on both sides, while in $C$. zillosus only the three first segments are so distinguished; and finally, in the former the sides of the postpectus are covered with black hairs, and in the latter with cinereous.

\section{[r.MIILY SHIPHID.E.]}

[96.] 13. Nrakopiones veicurives Fabr. - length of body, $S$ lines. Taken in Nova Scotia by J)r. MacCulloch. [Common in Ontario.]

Body black: nose separated posteriorly from the front by a straight line, anteriorly furnished with a submembranous rhinarium, above which is a round flattened tubercle; knob of the antenna black : prothorax dilated anteriorly, thickly covered with golden pile: elytra with two orangecolourcd bands, toothed as it were on both sides, the anterior being the widest; epipleura pale yellow: postpectus covered with golden pile : posterior trochanters truncated at the apex and emarginate.

135. Necrophorts hebes Kirby--Iength of hody; $;$ lines. Taken in Nova Scotia by Capt. Hall.

[97.] Like the last, but the nose is separated from the front by a curved line, it is also marked on each side by a deep longitudinal furrow, ano is depressed longitudinally in the centre; but what more strongly characterizes it, is the want of the rhinarium or nostril-piece discoverable in most of the other species : the anterior part of the prothorax is less conspicuously dilated and naked: the clytra anteriorly have a strongly toothed orange band including a black dot at the suture; posteriorly they have a large toothed spot of the same colour ; the epipleura is orange in the middle, black at the tip with a black spot at the base connected with the black disk: postpectus not brilliant with golden pile. [Unknown to Dr. LeConte. 1

136. Necrophorts OBSCuRt's Kirby.--Length of body 9-10 lines. A pair taken in the journey from New York to Cumberland-house.

Body black. Nose separated from the front by a straight abbreviated line, with a deep oblique furrow on each side and no distinct rhinarium; three last joints of the knob of the antenna ferruginous : prothorax 
anteriorly dilated: elytra with two rather obscure deep red bands, the anterior one broad, dentated and reaching from tice epipleura to the suture : the posterior one externally broad, internally narrow, and reaching neither epipleura nor suture; epipleura deep red, narrower than usual : posterior trochanter emarginate. [Taken in Canada : at Toronto by Mr. Couper, and at Grimsby by Mr. ['ettit.]

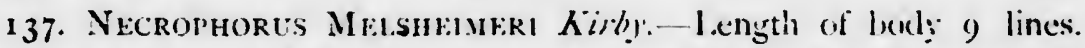
A single specimen taken in the journey from New York to ('umberlandhouse.

[98.] Body black. Nuse separated from the front by an obtusangular line; rhinarium orange-coloured, subtrapezoidal; three last joints of the knob of the antennie ferruginous: prothorax dilated anteriorly: elytri with two orange-coloured subundulated toothed bands reaching from the epipleura to the suture; epipleura broad. orange-coloured : posterior trochanters truncated at the ajex with the external angle recurved; tibia dilated, especially the anterior part, or cubits: postpectus on each side covered with tawny hairs. [Taken at '] oronto by Mr. Couper.]

${ }_{3} 3$. Necrophorl's Haldu Kirby.-I.ength of body 8-9 lines. Taken in Nova Scotia by Capt. Hall, and in Massachusetts ly Mr. Drake.

Body, as usual, black. Nose separated from the front by a straight line, channelled ; rhinarium distinct, membranous, tawny, anterior angles elongated; knob of the antenna with the three last joints dull-orange: prothorax neariy circular, anteriorly emarginate: elytra with an anterior angular band which does not reach the suture, and a posterior crescent or kidney-shaped spot, both of a deep orange: epipleura black ; wings dusky: trochanters emarginate at the tip.

139. Necrophores PYantes Kirby.--Plate ii., Fig. 3.-length of hody 6 lines. A single specimen taken in the Rocky Mountains. ['Taken at Grimsby, Ont., by Mr, Pettit: north shore of Lake Superior (Agassiz).]

[99.] This is the smallest known species of the genus. Nose separated by a nearly straight line from the front ; rhinarium transverse, not membranous ; knob of the antennæ black : prothorax nearly circular, there is a slight sinus on each side, and a deeper anterior one: elytra with an anterior angular band clilated at the epipleura, and a nearly semicircular spot at the apex of a dull deep red; epipleura of the same colour but black at the apex, and with a black spot at the base: posterior trochanters emarginate at the tip.

140. Necrodes [Sirpha] Surixampisis Fabr-- Taken in Nova Scotia by Dr. MacCulloch. [Abundant on carrion in all parts of Canada.] 


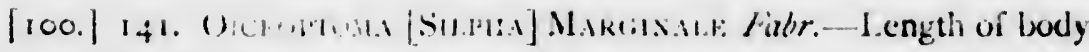
6 lines. Several speriment taken in Iat $54^{\circ}$, taken also by Dr. Mar Culloch in Nova Sicolia!.

Body oblong, bluth wery thichly pmetured. Head witi an oblong pimctiform impression in llic space between the eyes : the margins of the prothorax, the lateral more videly; are of a pale-red: the whole disk is covered by a large threc-lolerl hlack spot, with the lateral lobes the smallest and shortest : the elytra are reddish-Lrown with three longitudinal ridges, the exicmal one, as usual, stopping short of the apex. In the female the elytra at the apex are sulsinuated and subacuminater. [Very common throughout Canada.]

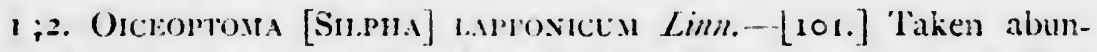
dantly both in the journey from New York to Cumberland-house, in Lat. $65^{\circ}$, and in Camada by Dr. Bigsiby. This species abounds in the huts of the Laplanders, derouring every thing-skins, flesh, and dried fisi. [Very common throughout Canada. For description ride Say's Ent. Works ii., 122, who described it as a new species umder the name of $S$. candatu.]

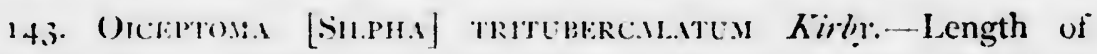
body $4 \frac{1}{4}$ lines. Sieveral specimens taken in the journey from New York to Cumberland-house, and in I.at. $54^{2}$.

[102.] This species aplears to be the American representative of Silpha "ficit, from which it differs in being smaller, and proportionally narrower: the prothorax is longer in proportion to its width, and has an obsolete channel: the elytra are more distinctly punctured, and besides the ordinary elevation at the termination of the external ridge, have two smaller ones at that of the other two ridges: the ridge next the suture also is more elevated at its termination than in $S$. opaca, of which in every wher sect it is the exact counterpart. The elytrit of the female are slightly sinuated at the apex, and olstusely acuminate. Variety $\mathrm{B}$. Quite black.

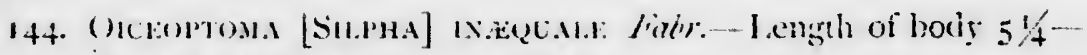
6 lines. Same localities as the preceding.

Body black, not at all glossy, minutely punctured: pinctures not visible except under a good lens. Three last joints of the antennx cinereous : prothorax anteriorly emarginate with four discoidal obtuse ridges, the lateral ones undulated and oblicue and the intermediate ones straight and parallel : elytra with the three customary longitudinal ridges, the outermost the shortest and most elevated, and the intermediate one towards the apex curving inwards : in the female the apex of the elytra is 
snbacuminate and very acute, but with scarcely any sinus; in the male it is rounded. [Quite common in Canada.]

[103.] 145. Oiceoptoma [Silpha] Americanum Linn.-Length of body $8 \mathrm{~s} / 2$ lines; breadth 7 lines. Taken in Nova Scotia by Capt. Hall.

Body very much depressed, thickly punctured with a hair issuing from each puncture; on the under-side black. Head with a round impression between the eyes; prothorax pale-yellow with a subquadrangular sublobate black spot in the disk ; punctures of the prothorax very thick, those of the discoidal spot resembling scratches; elytra brown-black, rather silky, with two longitudinal, undulated, obsolete ridges that do not reach the apex; their surface is covered with irregular elevations, and near the suture is a series of punctiform impressions ; epipleura very wide with its horizontal portion resplendent with a lustre between bronze and gold, vertical part, or inner margin, yellow; the suture of the elytra terminates in a minute point. Olivier says there are three ridges on the elytra, but only two are discernible in the specimen here described. It is singular that no author has noticed the brilliant sirle-covers of the elytra. [Synonymous with S. peltata Catesby. Common in Canada ; north shore of Iake Superior (Agassiz).]

146. Oiceoptoma [Silpha] terminatum Kirby.-I.ength of hody $9 \% / 4$ lines. Taken in Nova Scotia by Capt. Hall.

This species seems nearly related to $O$. Americanum, but it is narrower in proportion to its length, the front has a distinct oblong impression; the elytra are yellow at the apex and acuminate, which last is probably a sexual character; the epipleura is less brilliant than in the preceding species, and the elytra are not silky. In other respects it resembles it and may possibly be the female. [A variety of Silpha peltata Catesby ; taken at Toronto by Mr. Couper.]

147. Oiceoptoma [Silpha] AfFine Kirby.-Length of body 9 lines. Taken in Nova Scotia by Dr. Mac Culloch.

Very like the preceding species, but the frontal impression is smaller and round: the discoidal black spot of the prothorax is smaller, with the lateral lobes rounded, and with round confluent punctures : the horizontal part of the epipleura is black with a slight tint of blue, and not at all bronzed. [Also a variety of S. peltata. Taken at Toronto by $\mathrm{Mr}$. Couper ; and on north shore of Lake Superior by Agassiz's Expedition.]

[i04.] 148. Oiceoptoma [Silpha] Canadensf. Kirby.-Length of body 7 lines. Taken in dead fish on the shores of Lake Huron in Canada, by Dr. Bigsby.

This species approaches near to $O$. Americanum, but it is smaller, 
the frontal impression is deeper and otlong; the discoidal spot of the prothorax is much larger, extending from the anterior to the posterior Inargin, it is scarcely at all lobed, and only the punctures of its posterior part exhibit the appearance of angular scratches; the elytra are dirtyyellow at the apex, and the yellow occupies a much greater portion of the extremity than in the two preceding species, they are not acuminate at the tip, but have a very slight tendency to a sinus; the epipieura in colour resembles that of $O$. Americanum, but is less brilliant. [Also a variety of $S$ peltata.]

\section{FAMII.Y TROGOSITIDE.}

149. Peltis ferruginea Linn.- - Iength of body 5 lines. A single specimen taken in the journey from New York to Cumberland-house. The insects of this genus are usually to be met with under the bark of trees, and in fungi.

[105.] Body oblong, flat, ferruginous, resembling greatly, as De Geer has observed, the common bed-bug. Head thickly functured; prothorax deeply cmarginate for the reception of the head, thickly punctured; lateral margin sloping, reflexed: disk of the elytra with six elevated ridges gradually diminishing in length from the suture outwards; between the ridges is a double row of punctures, each pair of punctures being connected by a transverse furrow; outside the discoidal ridges are several irregular rows of punctures; lateral margin reflexed; epipleura linear at the apex, gradually dilated at the base. [Taken in Canada.]

\section{FAMII.Y NITIDULIDE.}

150. Nitidula obscura Fabr. - Length of body $2 \frac{1}{4}-2 \frac{1}{1 / 3}$ lines. Several specimens taken in Lat. $65^{\circ}$.

Body subdepressed, black, with its lustre obscured by inconspicuous decumbent subcinereous hairs. Head minutely punctured, transversely impressed between the eyes; occiput elevated; mouth and stalk of the antennæ piceous: prothorax minutely punctured, most visibly at the sides, which are depressed; lateral margin reflexed; elytra very obtuse at the apex, they have the appearance of being acuducted which seems to be produced by the pubescence : legs piceous or rufo-piceous.

[106.] 151. Nitidula Ossium Kirby. - Length of body $11 / 2-13 / 4$ lines. Several specimens taken in Lat. $65^{\circ}$.

Mr. Stephens regards this as a variety only of the preceding species, but it is smaller, narrower in proportion, the legs and stalk of the antennæ are paler, and the elytra and sides of the prothorax, in the British as well as Anerican specimens, are piceous. In other respects they agree. 
152. Nitidula DiscoIDEA Fabr. - Length of body $1 / \frac{1}{3}$ lines. Many specimens taken in Lat. $65^{\circ}$.

Considerably smaller than the British specimens. Body subdepressed, black, above minutely punctured, subpubescent. Stalk of the antennæ; sides of the prothorax, which has posteriorly a pair of discoidal obsolete impressions, legs and anus, rufous; elytra with a large anterior discoidal suborbicular pale-rufous spot common to both, in which, in some sperimens, is a black dot ; apex of the elytra obscurely variegated with rufous. Fabricus, and after him Mr. Marsham, describes the legs of this species as black; but others have properly denominated them by the term ferruginous and piceous. In the American specimens they vary in colour from piceous to pale-rufous.

[107.] 153. IPS DE JE.ANII Kirby. - Plate ii., fig. 4.-Length of body $21 / 4$ lines. Three specimens taken in 1 at. $65^{\circ}$.

Body linear, depressed, thickly and minutely punctured, glossy, black or dark piceous. Head with a punctiform impression in the vertex, and a larger impression on each side between the eyes : prothorax quadrangular, rather narrowest behind: elytra piceous or rufo-piceous, with two oblong white spots at the base, forming an interrupted line, and two oblique nearly parallel ones below the middle; legs piceous. In the other sex the elytra are subacuminate. VARIETY $\mathbf{B}$. With five white spots, viz.: 1, 2, 2. [Taken in Canada ; and north shore of Lake Superior (Agassiz).]

[ro8.] 154. Choleva (Catops) Spenciana Kirby.-Length of body 2 lines. A single specimen taken. Locality not stated.

Body black, covered with decumbent pale hairs. Head minutely punctured; antennæ shorter than the prothorax, the two first joints ferruginous, the eighth shorter and smaller than the rest; mouth and palpi ferruginous; prothorax not visibly punctured with all the angles rounded; base with a slight sinus on each side; elytra acute, very minutely punctured with a hair emerging from each puncture, without furrows except a single one parallel with the suture, ferruginous, black at the tip ; abdomen piceous, rufous at the base : legs ferruginous. [Belongs to the family Silphidce.]

\section{[109.] FAMILY SCAPHIDIIDE.}

155. Scaphium Castanipes Kirby.-Plate v., fig. 1.--Length of body 3 lines. A single specimen taken in the journey from New York to Cumberland-house.

Body naked, glossy ; underneath smooth, black, with a very light shade of bronze; above more evidently bronzed, punctured. Mouth, palpi, and antennæ pale chestnut : prothorax behind, on each side, marked with 
a pair of punctiform impressions, between these impressions are several large punctures, but not in a regular transverse series as in Scaphidium; elytra with six discoidal rows of punctures; the four rows nearest the suture reach the base, but not the apex, and the two external ones neither base nor apex; the first row also terminates towards the base in three large distinct punctures, and from the base of the third runs a transverse row, as in Siaphidium, to the sutural furrow, which is impunctured: the egs are pale chestmut.

\section{[1 10.$]$ FAMILY ANISOTOMIDE.}

156. Leiudes puncto-striatus Kirby.-Length of body a line. A single specimen taken in Lat. $65^{\circ}$.

Body hemispherico-ovate, naked, glossy, chestnut. Head very lightly punctured ; mandibles rather prominent ; palpi and antennæ rufous, clava of the latter much incrassated consisting of five joints, the second of which is extremely minute : prothorax very large, wider than long, very lightiy punctured, with the sides paler than the disk: elytra deeply and grossly punctured in rows, interstices impunctured; legs and under-side of the prothorax rufous : anus paler than the rest of the abdomen. This species closely resembles the Anisotoma badia of Sturm, bat the elytra are not finely punctured, as Mr. Stephens describes them in that species.

\section{FAMILY SYLVANIDE [LATHRIIIDE.]}

157. Corticaria nenticulata K̈irby.-Length of body 1 line. A single specimen taken in Lat. $65^{\circ}$.

[I 1 I I.] Body dark piceous, rather glossy, naked, minutely punctured. Prothorax rather orbicular, with a circular deepish impression just above the scutellum; sides distinctly denticulated: elytra with several rows of punctures. The insect here described approaches very near to $C$. impressa Marsham, but it is sufficiently distinguished not only by its colour but chietly by the very visibly denticulated sicies of its prothorax. [As the pecific name of this insect is preoccupied, it has been named $C$. Kirbyi by Dr. Le Conte. Taken by Agassiz's Expedition on the north shore of Lake Superior.]

\section{FAMILY CRYPTOPHAGIDAE.}

[1. 2.$]$ I 58 . Atomaria ATra Stephens. - Length of body $2 / 3$ line. One. specimen only taken.

Body black, punctured, glossy. Mouth reddish ; antennæ -rufous : elytra pubescent, piceous, rufous at the tip : anus and legs rufous.

159. Cryptophagus humeralis Kirby.-Length of body $13 / 4$ lines. Several specimens taken in Lat. $54^{\circ}$.

Body subcylindrical, black; above punctured and pubescent, rather 
glossy. Prothorax rather widest behind, with the basilar angles somewhat depressed: scutellum transverse, obtusangular: shoulders of the elytra obscurely rufous : legs, especially the tibire and tarsi, pale chestnut.

r6o. Cryptophagus concolor Kirby. - Length of body $1 \frac{1}{2}$ line. A single specimen taken in Lat. $54^{\circ}$.

[113.] In shape, sculpture and pubescence this species resembles the preceding, but it is smaller, and the whole insect is entirely of one colour -dark ferruginous.

N. B.-The two species last described differ from the other Crypto. phagi in having the thorax without serratures or denticles, and the scutelium obtusangular, and may perhaps forn $\mathrm{i}$ a subgenus.

FAMILY DERMESTIDE.

161. Attagent's cylindricus Kirby. Plate vii, fig. 3.-Length of body 2 lines. Two specimens taken in the Rocky Mountains.

This little species has much the air of a Cryptophagus, but belongs to the present genus. The body is subcylindrical, dark-piceous, very minutely punctured, and covered, but not thickly, with decumbent cinereous hairs. The two first joints of the antennæ are large, globular, and of the same colour with the rest of the body; the intermediate ones very minute and pale rufous; the three last are incrassated and form an oblong piceous knob, of which the terminal joint is as long as the two preceding ones, ovate and acute: the prothorax behind is very obsoletely trilobed with the intermediate lobe rounded: the tarsi are rufous. [Unknown to Dr. Le Conte.]

[114.] 162. ATtAagenus PELlio Linn.-Length of body $23 / 4$ lines. Taken in Nova Scotia by Capt. Hall.

This species, though particularly destructive to furs, is to be met with in other animal matters, and is very common in houses. De Geer describes its larva as having a very long bc dy covered with a hard, shining skin of a reddish-brown colour and hairy; as having six legs, and the posterior extremity terminated by a long remarkable tail, formed of rufous hairs as long as the body, and placed horizontally in the same line. $\mathrm{He}$ says that their motion is gliding, but by snatches.

The American specimen, which is a male, is considerably larger than my British ones and blacker; but in other respects it precisely resembles them. The species may generally be known by its black or dark-piceous solour,-covered, especially underneath, with decumbent whitish or cinereous hairs. The stalk of the antennæ, and the tarsi, are testaceous, and the last joint of the former, in the male, is longer than the two first and 
cylindrical: the prothorax at the three posterior angles has three white spots formed of hairs, and the elytra are in the middle near the suture. [T'aken in Canada.]

[1 115.$]$ I 63. DERMESTES LARDARIL'S Linn.--Taken in Nova Scotia by Capt. Hall; in Massachusetts by Mr. Drake. Latreille observes that this insect is found in every quarter of the old world. [We may add, in the new as well. It is a great pest to collectors in Canada.]

164. Dermestes inssector Kirby. - Length of body $3 \frac{1}{1 / 3}$ lines. Taken by Dr. Bigsby in Canada. [Apparently identical with Say's $D$. nubilus (Ent. Works, i. p. 300), which differs little, if at all, from $D$. caninus Germ. Not uncommon in Canada.]

[116.] 165. ByRrhus pICIPES Kirby.-Length of body $3^{\frac{6}{6}}$ lines. A single specimen taken in Lat. $54^{\circ}$.

Body black, covered with short decimbent hairs. Scutellum velvettyblack : elytra with a pair of deep black interrupted stripes terminating in a transverse abbreviated posterior band of the same colour: legs piceous. [As this specific name is preoccupied, Le Conte has named the species B. Kirbyi. It is taken in Canada from Quebec to the north shore of Lake Superior.]

[117.] I66. BYRRHLis CONCOLOR Kirby.-Length of body 3 lines. Two specimens taken in Lat. $54^{\circ}$.

This nearly resembles $B$. picipes, but it is much smaller, the prothorax is more distinctly channelled, the elytra have no black band, and the legs are black. [Supposed by Le Conte to be a variety of Cytilus varius Fab.]

167. Byrrhus cyclophorus Kirby.--Length of body $3 \frac{1}{4}$ lines. One specinien only taken.

Body underneath and limbs dull ferruginous, above black with some cinereous hairs intermixed. Antenne piceous: elytra with two deep black sub-interrupted stripes, and inscribed in the middle with traces of a circie formed of pale, or cinereous hairs, common to both. The circle is probably more distinct in recent specimens. [Taken at Grimsby, Ont., by Mr. Pettit, and at Toronto by Mr. Couper; north shore of Lake Superior by Agassiz's Expedition.]

[1 18.$]$ I68. BYrRhLis varius Fabr.-Length of body $23 / 4$ lines. Several specimens taken in the journey from New York to CumberlandHouse.

Body underneath black. Head and prothorax bronzed, the gloss obscured by glittering hairs, above the scutellum is a patch of golde:s ones: scutellum channelled, covered with paler hairs: elytra slightly 
furrowed, bronzed, with the alternate interstices of the discoidal furrows green-bronzed, spotted with little velvetty patches of black hairs. [Bclongs to $C y$ tilus; not uncommon throughout Canada.]

\section{[IIg.] FAMILY HYDROPHILIDE.}

169. HydRoBICS FUSCIPES Linn.-Length of body 3 lines. A single specimen taken in Lat. $65^{\circ}$.

Body oblong, convex and rather vaulted; underneath black, very minutely and thickly punctured with a pale short decumbent hair planted in each puncture ; above slightly bronzed, more conspicuously punctured, naked and rather glossy. Head slightly impressed on each side between the eyes; palpi pale rufous, last joint dusky at the tip: antennæ rufous with a black knob: sides of the prothorax with two or three groups of larger punctures: elytra furrowed with thickly punctured furrows, dusky rufous at the sides: legs dark rufous, base of the thighs black. This is smaller than my British specimens, the furrows of the elytra are rather deep, and their sides more conspicuously rufous. [Taken in Canada.]

[1 20.] I70. Hydrobius Marginellus Fabr. - Length of body $12 / 3$ line. Two specimens taken in Lat. $54^{\circ}$.

Body sub-elliptical, convex, minutely punctured, black; above glossy. Palpi and antenuæ dusky rufous; knob of the latter black: sides of the prothorax, and the anterior margin dusky rufous: elytra with a single furrow adjoining the suture; sides dusky rufous : tarsi rufous.

I7 1. Hydrobius melanocefHalus Oliv.-Length of body $2 \frac{1}{4}-2 \frac{1}{2}$ lines. Two specimens taken in Lat. $54^{\circ}$.

[1 2 I.] Body sub-elliptical, minutely punctured; underneath black, somewhat hairy with very short inconspicuous hairs, above lurid or dirty yellow, glossy, more conspicuously punctured. Head black with a quadrangular yellow spot before each eye; nose gibbous, separated from the front by a transverse angular line; palpi and antennæ dirty-yellow, the latter with a black knob: prothorax with a dark, discoidal, subquadrangular spot, which does not reach the anterior margin: shoulders with a dusky line : tibiæ and tarsi dusky rufous.

Var. B. Larger, dusky rufous above, spots before the eyes larger and subtriangular : black spot on the prothorax wider but not so near the anterior margin; shoulders of the elytra without a dusky line. [This and the preceding are European species; Kirby's descriptions of them are not sufficiently definite to enable them to be identified with any of the species described by Le Conte in his "Synopsis of the Hydrophilida of the United Stat ss." (Pro. Acad. N. S., Philada., June, 1855).] 


\section{[ 1123.$]$ FAMILY HISTERID.E.}

172. Hister Paykllil Kirby.-Length of body $3^{\frac{1}{b}}$ lines. One specimen taken in the journey from New York to Cumberland-house.

Body black, glossy. Head circumscribed by a rather deeply ploughed furrow; antennæ piceous with a pale knob; mandibles longer than the head: prothorax rather wider behind, seemingly quite smooth, but under a strong magnifier it appears thickly covered with very minute lightly impressed punctures ; it is circumscribed on all sides, by a deepish furrow, between this furrow and the lateral margin is another abbreviated one less inpressed ; elytra besides a distinct marginal furrow have three discoidal subpunctured ones running from the base to nearly the apex; between the external discoidal furrow and the margin is a series of punctures near the apex, representing what is called the marginal furrow, and between the internal one and the suture are the traces of three others, the first just discernible, drawn, but interruptedly, from the base to the apex; the second consisting of three or four punctures near the apex, and the third parallel with the suture, consisting also of punctures, sometimes confluent, and extending from the apex not quite half the length of the elytrum; the surface of the elytra is covered with minute punctures very lightly impressed, so as not to be discoverable except under a good magnifier: the cubit or anterior tibia is armed with three teeth, the last of which appears cleft from its being furnished at the apex with two short truncated transparent bristles, the two other teeth have only one such bristle.

[Synonymous with $H$. depurator Say (Ent. Works ii. 261), a species found in Canada, and taken by Agassiz's Expedition on the north shore of Lake Superior.]

173. Hister Harrisil Kirby.-Length of body $3 \frac{1}{4}$ lines. One specimen taken in the journey from New York to Cumberland-house.

Body black, glossy, thickly punctured, the punctures on the uppersurface being most conspicuous. Head circumscribed; antennæ and palpi nearly of a mahogany colour : mandibles longer than the head; nose slightly impressed : prothorax with two furrows at the lateral margin, both nearly reaching the base, the inner one, as usual, when arrived at the anterior margin, with the corresponding one on the other side forming one furrow surrounding the prothorax on three sides; just above the scutellum is a punctiform impression: the elytra, including the submarginal one, have seven distinct furrows, the two next the suture being anteriorly 
abbreviated and very shor:, especially the first ; from the base of the first, or external discoidal one, an obsolete furrow runs obliquely towards the submarginal one; the four discoidal entire furrows when arrived near the apex of the elytra are bent towards the suture : cuisit picenss, armed with five teeth, the three cuter ones obtuse. [Taken at Crimsby, Ont., by Mr. Pettit. 7

\section{[125.] Lamellicornia.-Family Coprid.e [SCarab.ĩ.id.e.]}

174. Onthophagus latebrosus Falir.-Length of body, $\hat{\delta} 3 \frac{1}{2}$ lines; $q 3-33 / 4$. A single specimen of the $q$ taken in the jolimey from New York to Cumberland-house; a $\hat{0}$ taken in New England by Prof. Peck.

The species of this little interesting genus, remarkable for the great variety of processes resembling horns, that arm the head of the males, are as widely dispersed as those of any genus of beetles; they are to be found in every climate from the frigid to the torrid zone, nor do they increase in size as they recede from the former and enter the latter, for the most minute species are to be found in Southem Indit, where they abound, while the largest secm to inhabit temparate climates.

f Body entirely black, except the land: or anterior tursi, which are rufous : gloss obscured by hairs. Nose at the apex bent upwards, forming a vertical, triangular, acute tooth; on the vertex are two obsolete transverse ridges : the prothorax is rough with little granules, and anteriorly sends forth a longish wide horn truncated at the end and overhanging the head: the two angles of the apex are clcrated, and the spaic between them is defiexed, and bidentate : the cubits are armed with four sharpish teeth.

The female differs from the male nerely in having the shield of the head more distinctly notched on each side, and the apex of the nose rounded and reflexed, but without any triangular horn or tooth ; in having two distinct ridges on the vertex, and in having $n o$ prothoracic horn, which is replaced by a transverse emarginate ridge in the middle. [Quite common everywhere throughout Canada; genera!ly found in ler the droppings of horses o: cattle.]

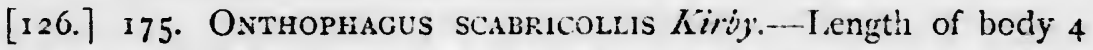
lines. A single $q$ specimen taken in Canada by Dr. Bigsby.

This is so like the last insect that I felt at first disposed to consider it as merely a variety. The following differences in their character induce me however to consider them as distinct. Not to mention the difference of size, the female of 0 . latelrosus has a distinct notch on cach side of the 
head, of which there is no trace in $O$. sianirialiis, the ridges of the verter of the latter are more elevated, the prothorax is larger in proportion and much rougher, with larger and more numerous granules, and the four teeth of the cubit, which in the former are long and acute, in the latter are shorter and obtuse.

176. Trox arenarius Fabr.-.iength of body 3 lines. liaken by Capt. Hall in Nova Scotia.

[127.] Body oblong, black, without any gloss. Head rovered with cinereous varioles; nose a little reflexed, rounded with a slight tendency to be obtusangular; antennæe ferruginous; prothorax with a wide rather obsolete dorsal channel; sides with two impressions, one near the anterior angle, and the other basilar in the disk; base lobed : litcral margin fringed with ferruginous bristles : elytra slightly furrowed, interstices with cach a series of elevations crowned with brown bristles, the elevations of the alternate series are minute; anterior tibia with three acute tecth, they are also serated at the base. [An European species, not found in Canada.]

177. Pelidnota punctata Linn.-Taken by Dr. Bigsby in Canada. near Lake St. Clair. [Abundant, and often very injurious to the foliage of the grape-vine throughout the Western peninsula of Ontario ; it does not occur, however, as far east as Toronto. For description and illustrations, see "First Report on the Noxious Insects of Ontario," Saunders's Report, page 106 ; or Harris's "Insects injurious to Vegetation," p. 25 ; Fitch, Riley, Packard, etc.]

[129.] 178. Camptorhina atracapilia Kirby.--Length of body $5 \%$ lines. Taken in Canada by Dr. Bigsby, and in Nova Scotia by Capt. Hall. [Synonymous with Serica vespertina Schonh., a species taken commonly throughout Ontario, and, according to Dr. Le Conte, in the Middle, Southern, Eastern and Western States, as far as Iake Superior. For description vide Say's Ent. Works, ii., p. I43.]

Genus Diplotaxis Kirby.-Labrum transverse, lanceolatc, anteriorly emarginate. Mandibles very short, trigonal, incurved, truncated and concavo-convex at the apex; molary space small, irregular, channelled? Maxillæ very sitort, incurved, incrassated at the base; apex armed with three short, stout, conical teeth. Labium very short, transierse, entire, separated by a faint line from the mentum. Mentum quadrangular, rather wider than long. Palpi maxillary four-jointed, very minute, cylindrical ; second and third joints thicker, equal in length, obconical ; last thickest and longest, lanceolate-ovate, acute. Palpi labial three-jointed ; first joint obconical ; second subcylindrical ; third nearly as long as the other two, but scarcely thicker, conical. Antenna ten-jointed: scape elongato- 
obconical ; pedicel nearly spherical ; third and fourth joints conical ; fith and sixth nearly top-shaped; seventh pateriform; the three last forming a short ovate knob.

[r3o.] Body between oblong and ovate, not hairy. Head inserted, subtriangular with the vertex of the triangle truncated; rhinarium transverse, vertical, widely emarginate ; nose transverse, distinct, anterior margin reflexed and subemarginate; no distinct postnasus or afternose ; canthus septiform, cleaving : prothorax transverse with an anterior sinus of its whole width to receive the head: scutellum short, triangular, somewhat rounded at the vertex : podex and part of the penultimate dorsal segment of the abdomen uncorered : legs thus located :: ; cubit tridentate ; tarsi filiform, slender ; claws bipartite, the interior lobe the shortest and widest, and very obtuse ; the exterior very slender and acute.

179. Diplotaxis tristis Kirby.-Plate v., fig. 3.-Length of body $5-51 / 2$ lines. Several specimens taken in Lat. $54^{\circ}$. Taken also in Nova Scotia by Capt. Hall.

[13I.] Body dark chestnut, more or less grossly punctured above and below. Head thickly punctured with a pair of impressions between the eyes; nose subemarginate; antennæ and palpi rufous : prothorax thickly punctured, slightly impressed at the four angles : scutellum impunctured : elytra rather paler than the head and prothorax, with nine rows of punctures, viz., a single one at the suture, four arranged in pairs at the disk, and four in the sides; the interstices between the rows are also irregularly punctured; the four posterior tarsi, especially the intermediate pair, are longer than the tibiæ.

OBS. In more recently disclosed specimens the body is often entirely pale-chestnut and sometimes rufous. [Common throughout Ontario. "Middle States and Lake Superior, not rare." Le Conte.]

[132.] 180. Rhizotrogus FERvens Gyll.-Two specimens taken in Lat. $54^{\circ}$; a variety in Canada by Dr. Bigsby. [Synonymous with Lachnosterna fusca Frohl ; the common May Beetle, or Cockchafer, of Canada. "A very common and, through Atlantic America, widely extended species, embracing several races, to which, however, no definite characters can be given." (Le Conte). For description and figure see Harris's Injurious Insects, page 30.]

[133.] 181. Rhizotrogus Drakil Kirby. - Length of the body $91 / 4$ to $1 \mathrm{I} / 4$ lines. A single specimen taken in the journey from New York to Cumberland-house. Varieties B and C, by Mr. Drake in Massachusetts.

This species is extremely similar to the last, it differs principally in having the sides of the scutellum more thickly punctured, the ridges of the 
elytra, except the sutural one, are scarcely discoverable. and the podex larger and rounder at the apex : the tarsi also are longer in proportion: the knob of the antenna in all the specimens is longer.

B. Much larger, and the elytra appear somewhat mori thickly punctured, but it is scarcely distinct.

C. Like $\mathbf{A}$, but the ridges of the elytra are all discernible. [A race of the preceding species.]

Genus Dichelonycha Marris.-Labrum transverse, lanceolate, scarcely emarginate. Mandibles short, trigonal, incurved, toothless, acute : molary space transverse, furrowed. Maxillæ minute, linear, bidentate, with short teeth. Labium subquadrangular, not distinct from the mentum. Palpi maxillary four-jointed; first joint very minute; second longer than the third, obconical ; third triangular ; last joint as long ats the three others together, very large, súbsecuriform. Palpi labial three-jointed; joints short, subfiliform; last truncated. Antenna nine-jointed; scape obconical, incrassated; pedicel subspherical; third and fotrth joints subfilifurm ; fifth obconical; sixth subturbinate; the three last forning a short subovate knob. Body narrow, subcylindrical. Head sturequadrangular ; nose transverse, separated by an indistinct obtusangular ine, anteriorly reflexed: rhinarium transerse marked with a tanswerse series of rather large punctures; eyes prominent; canthus entering : prothoras hexagond, the sides being obtusangular: scutellum rouncled at the vertex. dilated at the base : elytra linear, rounded at the apex, obsoletely :idged, wrinkled; cpipleuria vertical, narrow : legs rather slender; hind legs long; cubit tridentate: tarsi filiform; claws equal, all bitid at the apex : podes subtriangular.

[134.] This genus evidently lelongs to the same family with Macrociactylus, from which it is distinguished by having its maxilla armed only with two teeth, the last joint of its pulpi of a different shape, and its labium approaching to a square form: whereas in the latter genus the maxilla are more conspicuous and armed with three teeth, the last joint of the palpi is subovate, and the labium is oblong and channelled.

The species of this genus, as far as at present known, appear to be confined to the more northern parts of the new world; 1 have seen none south of the province of Massachusetts, from whence I have received sjecimens both from Dr. Harris and Mr. Drake. Type of the genus Melolontha lincaris Herbst.

182. Dicheionxcha Backn Kirby:---Plate ii, fig. 6.--I.cngth of body $4 \frac{\mathrm{J} / 2}{2}$ lines. Several specimens taken in Lat. $54^{\circ}$.

Eody black, glossy, hairy, especially underneath, with white decumbent hairs; above thickly and coarsely punctured. Nose much refiexed, nar- 
gin entire; stalk of the antenna chestmut ; elytra silky, green, more or less bronzed.

VARIETY B. Antennx rufous. Tarsi pale chestnut. [Taken on norti shore of Lake Superior by Agassiz's lixpedition.]

$1 S_{3}$. Dicheloncha virescexs Kirly.-Iength of body $4 \frac{3 / 4-5}{4}$ lines. Taken in Canada by Dr. Bigsby, in Nova Scotia by Dr. Mac Culloch, in Massachusetts by 1)r. Harris, and in Pennsylvania by Dr. Horstield. Dr. Sigsby found it common on the different species of Salix.

[135] lind: piceous, thickly covered underneath, except the disl of the breast and ablonen, with decumbent snowy hairs, minutely punctured, p'mctures most numerou; on the upper side. Head nearly black. covered with glitterin's decumbent hairs; nose very obtuse and almost truncate, less reflesed than in D. Backii, reflexed part obscurely rufous; rhinarium, undersicic of the head, and mouth with its organs, rufous; antennae reddish-yellow: prothorax nearly black with the sides a little paler, with a longitudinal discoidal rather obsolete channel and an impression on each side; sprinkled with short glittering decumbent hairs : scutellum rufous, thickly covered at the base with whitish decumbent hairs: elytra reddish-yellow tinted with green, sprinkled with short decumbent whitish hairs, the hateral punctures are almost arranged in dense rows: abdomen rufous; podex thickly covered with snowy hairs: legss reddish-yellow; tarsi darker : !osterior tibiae black, reddish at the base; posterior tarsi piceous.

VARIETY B. Head and prothorax rufopiceous; legs rufous.

C. Head and prothorax rufous mottled with dusky; elytria with a green spot at the shotilders and tips; posterior legs entirely rufous : trunk rufous.

[This species is in all probability synonymous with $D$. clongatulit Schon., the var. $C$ belonging to D. sulnittata Lec. Both of these species are common in Canada: we have generally taken them upon various kinds of Oaks.]

184. Dichelosvicha Testacka Kirbyl--length of body $4 \frac{1}{3}$ lints. Taken by Dr. Bigsby in Canada.

Very similar to Variety $C$ of the preceding species ; but the body, with the exception of the eyes which are black, is entirely of one colour, rufotestaceous, the head, prothorax, and tarsi being rather darker than the rest; the eyes are larger and more prominent; the head and prothorax, especially the latter, are more thickly and minutely punctured; and in this there is no dorsal channel: its margins, especially the lateral, are more hairy, the elytra exhibit no humeral or apical green spot: and they 
are very slightly tinted wh that colour. ['Two females found at Fagle Harbour, Iake Superior, by Dr. Le Conte. Included in the list of Canadian Coleoptera.]

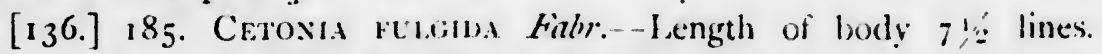
laken in Canada, at Lake St. Clair, by Dr. Bigshy.

Body depressed, of a beautiful glossy green. Head black underneath, above grossly punctured; eyes reddish-brown; antennae brown-black : nose anteriorly subemarginate and a little reflexed; prothorax with a triple posterior sinus, grossly but not thickly punctured, sides luteous : scutellum an isosceles triangle, impunctured: elytra, in some lights, luteous, in others with a shade of green; at the base grossly but not thickly punctured, the remainder of the elytrum is acuducted like net work; disk longitudinally depressed: podex lusky, luteous at the apex, with four triangular, white, basilar spots; abdomen underneath with : double series of triangular white spots on each side, the outer ones elongated : sides of the breast hairy; mesosternum suborbicular, hairy; legs luteous; tarsi and base of the cubits, brown-black. [This beautiful insect, now included in the genus Euryomia Burm., is taken occasionally, but not commonly, in Ontario.]

I86. 'Trichics BigsBu Kirby.-Length of body $z$ lines. Taken in Canada, near Lake St. Clair, by Dr. Bigsby.

[137.] This species exhibits the habit and general aspect of $T$. fasciatus, but it is larger and less hairy. Body obovate, black, covered more or less with tawny longish hairs. Head quadrangular; nose reflexed, emarginate; antennae and palpi luteous, black at the tip; prothorax trapezoidal, narrowest anteriorly, sides rounded or subobtusangular, posteriorly with an obsolete sinus near each angle; scutellum short, rounded at the apex : elytra without hairs, covered as it were with a bloom; luteous with a black margin and nine black spots-viz. one large one at the shoulders, seven in the disk arranged transversely 2, 3, 2, and one larger than the rest on the apical tumour; the humeral and apical spots are glossy : three tawny-yellow mealy spots, the intermediate one straight and longitudinal, and the lateral ones sinuated and oblique, mark the podex : the tibiae and tarsi of the four anterior legs are deep ferruginous; cubit bidentate, [Synonymous with Gyorimls maclioses Knoch. Taken, but rarely, in Canada.]

187. Trichius Assimilis Kirly:-1.ength of body 4 $1 / 4-5$ lines. Taken in Lat. $65^{\circ}$; in Nova Scotia by Capt. Hall ; and in Ma:sachusetts by Dr. Harris.

[138.] Body obovate, black, covered more or less with long yellowish 
hairs. Head punctured; nose retlexed, emarginate; stalk of the antennac testaceous, scape and knob black ; palpi dusky : prothorax punctured, less hairy in the disk, not channelled : elytra black, very short, depressed next the suture with an intermediate ridge; at the base is a large pale-yellow spot common to both elytra, from which run a pair of narrow, white, mealy bands, which nearly reach the external margin, and a white mealy stripe adjoining the suture also runs from the same spot to the apex of the clytrum : the podex is covered with long yellowish hairs, so thick on the sides as almost to conceal the oblong white mealy spot common to the subgenus : legs black.

N. B.-In the specimen taken in the Expedition, the white mealy stripe next the suture appears to have been rubbed off and and is replaced by a continuation of the pale suot. [1'reviously described as T. affinis (iory: Taken in Canada.]

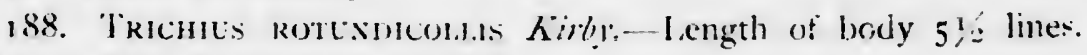
Taken in Nova Scotia by Capt. Hall.

Body obovate, black : covered, particularly underncith, with longish jale hairs. Head very thiclily punctured; nose reflexed, emarginate: stalk of the antennae, excluding the scape, testaceons: prothorax suborbicular, with the segment of a circle taken out next the head : very thickly punctured, channelled, sprinkled with short yellowish hairs; at the side of each of the four angles is a mealy-white spot: the elytra next the lateral margin have two transverse mealy-white streaks or bands, which are continued towards the suture by a broader, naked, ferruginous, obscure band: just below the scutellum. on each elytrum, is another mealy stripe, and parallel with the suture is an obscure, naked, ferruginous one: podex hairy with the ordinary mealy pale spots very conspicuous; it is sculptured with transverse undulated lines: cubits robust with two stout teeth: a mealy spot marks the base of the posterior legs. [Synonymous with $T$. figer Fabr. : taken commonly in Ontario.]

189. Trichies vikidaxs Kirby.-.- Iength of body th lines. I single specimen taken in Canada by Lr. Bigsby:

In the markings of its elytra this species agrees precisely with that last described, but the upper side of the body, especially the head and prothorax, is green; the latter is of a different siape and less thickly punctured; and the cubit and its teeth are less robust : the podex also is morc hairy. These can scarcely, all of them, be mere sexual distinctions.

It seems intermediate between $T$, rotundicollis and $T$. airidulus. variety of $T$. affinis (rory.] 
[140.] 190. TRICHICS RUGosts Kirby.--Length of body $101 / 2-13$ lines. Taken in Nova Scotia by Dr. Mac Culloch and Capt. Hall.

Body rather glossy, dark pitch-colour, naked above with a few scattered hairs on the underside and on the legs. Head above plane, thickly covered with impressions and punctures that anastomose and run into each other, in some specimens leaving here and there some elevated. levigated, narrow spaces: nose anteriorly transverse, reflexed: prothorax with a longitudinal postcriorly abbreviated channel ; sides obtusangular : surface covered, less thickly in the disk, with large, and often confluent, punctures : scutelli:m an isosccles triangle, channelled, with a few scattered large punctures on each side : elytra indistinctly furrowed, confluently and irregularly wrinkled, wrinkles marked with shallow indistinct punctures, interstices elevated: cubit acutely tridentate: podex transversely irregularly acuducted. ['This is a description of the female of Osmoderma scabra Dej., a species quite common in Ontario.]

191. Trichils foveatus Kirby--length of body $111 / 2$ lines. Taken in Nova Scotia by Capt. Hall.

Near the preceding species, but perfectly distinct. Body nearly naked, somewhat glossy, of a dark pitch-colour. Nose and front between the eyes with a very deep and large impression, the bed of which is acuducted in circles with a minute puncture in the centre of each; the rest of the head is confluently punctured; above the bed of the antennae the front rises into a rather lofty levigated prominence: the prothorax is shaped like that of $G$. rugosus, but is rather less obtusangular, the channel is decper, with its sides more elevated, and there are one or two slight impressions between it and the margin; the punctures on the disk are rather more numerous: the elytra are paler than the rest of the body and a little bronzed, the wrinkles of the surface are more vermiform than in the species just named, without any punctures, and the appearance of furrows is less distinct : the podex is distinctly punctured and scarcely acuducted ; and the cubit is sinuated rather than dentated, the three prominences being extremely obtuse. [A description of the male of Osmoderma siabra Dej.]

[141.] 192. Platycerus picels Wcl.-Length of body 6 lines. A single specimen taken in the journey from New York to Cunberlandhouse.

[142.] Body dark piceous, rather glossy, thickly punctured. . Nosc very retuse, or rather with a large sinus : niandibles shorter than the head, acute, armed on their inner side with a stout tooth with the segment of a circle taken out of it ; antennae jale chestnut : prothorax with the latera] 
margin obtusangilar, stberenate, and refiexed: dish longitudinaily impunctured, and obsoletely channelled : scutellum channclier! impunctured: elytra furrowed : cubit serrulate and denticulate, two sith teeth longer than the rest at the apex; tarsi chestnat. "Winis is the smallest species of the stag-beetle tribc. [llaced, with a mark of interogation, as a synonym

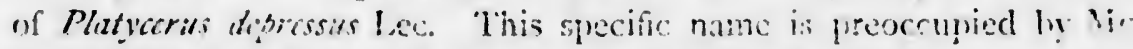
Leay's Ceruchus picus. I'. Diptrissus is taken in ('anada.]

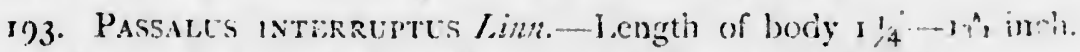
Many taken in the journey from $\mathrm{New}$ York to Cumberland-house.

Hody black or piceous, underneath sometimes nio-piceous, impunctured, glossy: Head with a crooked horn between the eyes pointing towards the month, and a triangnlar clevation adjoining each eye on the inner side; labrum with a deep sinus; mandibles with three teeth at the extremity, and one in the middle of the upper side; know of the antemner consisting of three hairy joints, the outer une thicker than the otiacs and curved: prothorax channelled. impresser? on each side near the base: under a powerfill lens severs! scattered very mintste punctures may he: discovered on its surface: the ora, or undersides of the protherex, sre likewise punctured, and sof with tawn hairs : elytra furrowed f firmos: punctured : cubit many-toothed : intemediate tibix densely losaled, on the outsicle, with tawny hair:

The bent or nodding horn on the isead of the species here clescribet has generally been taken for a sexial character; but I am inclined is regard this as a mistaken notion. Syecimens thus circumstanced, as far as I have been able to ascertain, have hitherto been found only in North America; while those with a tuberculated head are found in various paris of South America, in the East and West Indies: and I have one in my cabinet from New Holland. Fleven specimens of the former wcre collected in the Expedition, varying in size, and not a single one of the liatter. [Generally known by the Fabrician name of P. cormatus. Taken frequently. in the southern and western parts of Ontario.?

FAMII RIATFRIII:.

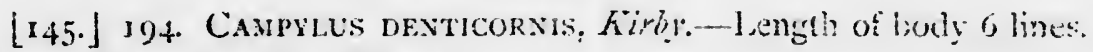
Taken in Canada by Dr. Bigsiby:

'This is the American representative of $C$. incsumcicis, from which it is sufiiciently distinguished by its toothed antennac and longer prothorax. Body linear, black, hairy with pale decumient hairs. Head punctured : antennae longer than the prothorax, filiform, with all the joints, except the scape, pedicel, and terminal one, terminating at their internal extremity in 
a prominent tooth, less conspicuous in the two lower ones $\cdot$ upper-lip, and nose which is reflexed and overhangs the mouth, yellow: prothorax channelled, punctured, (juadrangular, with the anterior angles rounded, and the posterior diverging and terminating in a sharp tooth or prominence; sides rather way, limb yellow: scutellum subcordate: elytra minutely and thickly punctured, slightly furrowed, furrows thickly punctured; marked with it marrow yellow stripe which does not reach the apex; there is also a short yellow streak on the shoulders: base of the tibiae, claw-joint of the tarsi, and claws yeliow. ["Lake Superior, Maine and Pennsyluania" (le (conte). We have specimens, taken in the neighlourhood of Ottawa, Ont.]

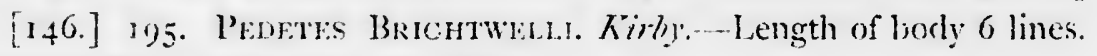
laken in Nora Scotia by Capt. Hall.

Body elongate, more slender than that of the type, testaceous; hairy; with derumbent pals hairs; thickly punctured. Head dusky-red; antwonac longer than the prothorax, slenderer than usual in the tribe, scarcely serrated, with the four last joints rather slenderer than the rest; eyes large and hemispherical : nose a good deal refiexed : prothorax convex, channelled, dusky-red, darker in the disk: elytra pale testaceous: furowed, furrows deeply punctared : interstices minutely punctured with sattered punctures: legs paler than the rest of the body, and nearly rellow. Lncluded now in the geilts Athols Esch. Le Conte, in his "Revision of the Elateride of the Lnited States," (Amer. Phil. Trans. rol. $\therefore, 1 .+25$ ). states that this species occurs in the "Midde and Southern states, not rare. The specimen described by Kirby seems to have been a pale coleured variety of this species, which varies much in colour. In the male the thorax is constricted before the posterior angles, which are slightly divergent: in the female, the sides are straight and the angles do not diverge : the dorsal channel is never deep, and is frequently wanting."

stegraces AsArHFs Kinly?

Body wide: Nose not overhanging the mouth. Rhinarium attenuated in the middle. Prothorax short, posterior angles carinated.

I an doubtful whether this should not be considered as forming a distinct genus. The general form is very different. But as the tarsi have sickers on the second and third $\mathrm{j}$ rints, till more species are discovered, I have given it as only a subgenus of Pedetrs.

[Dr. Le Conte (Am. Phil. 'Trans. x. 449) states that "although but one species of this genus is described by Kirby and another by Germar, 1 find that several of our Elaters possess characters which require them to be issociated with his type. 'They seem to form a natural group approach- 
ing most nearly to Corymbites, and indeed diftering from that genus only in the structure of the tarsi. The second and third joints of the tarsi are dilated beneath into a short spongy lobe: the first joint is as long as the second and third together, and uswally spongy at the tip : the fourth joini is small and narrow, received upon the third, and is sometimes also spongy bencath : the fifh joint is elongate with simple claws."]

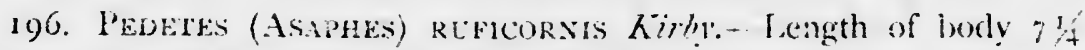
lines. Taken in Nova Scotia by Capt. Hall.

Body black, ratier glossy, minutely punctured, downy with pale down. Antennæ, month, and palpi rufous or dusky-rufous ; habrum and mandibles piceous; nose rounded, not reflexed, not overshadowing the mouth: antenne serrated on the inner side in the middle, last joint acuminated : prothorax short, widest behind, very obsoletely channclled, sides sulmargined; posterior angles dentiform, strongly carinated: clytra piceous, or rufo-piceous, very slightly furowed with oblong punctures in the furrows. interstices minutely punctured: margin of the abdomen and of the penultimate segment, rufons. [Previously described as Elater momonius Fierbst. Quite common in Canada : taken also in Waine, Ohio, Pennsykania, Alabama (Le Conte).]

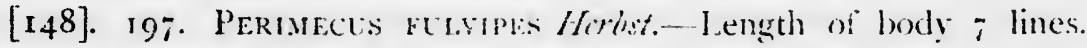
Taken in Canada by Dr. Bigshy.

Body black, punctured, glossy ; gloss and colour obscured by numerous decumbent pale hairs. Antenne pale chestnut, with the third joint double the length of the second : posterior angles of the prothora: carinated: elytra with nine rows of large and deep punctures, interstices minutely punctured : legs pale chestmut.

The only difierence that I can discover between the American and European specimens, is in the length of the third joint of the antennx, which in the latter is scarcely longer than the second; and this may probably be a sexual distinction. [Belongs to the genus Mclimotus Fsch.. and is synonymous with $M$. (Cratonychus) citsantipes Payk.]

198. Pekmects commoxis Gyll--1,ength of body 6y lines. Scveral specimens taken at Cumberland-house, I at. $54^{\circ}$.

Very similar to the preceding speries, but much smaller. Body shestint-coloured, clarker or lighter in difieront specimens, punctured, glossy, hairy : thitd joint of the antenne twice the length of the second: prothorax thickly punctured, obsoleteiy channelled, chiefly behind : elytra, antenna, and legs rather paler than the rest of the body, the former sculp- 
tured as in the last specice. ['Taken in Canada. "Abundant as far as Nebraska" (Le Conte). Beiongs to the genus Melanotus.]

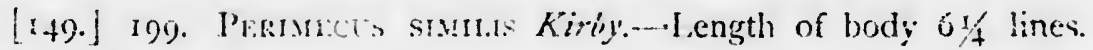
Thaken in I.at. $54^{3}$.

I should have given this as merely a variety of the last; bat besides ii) blacker body, the punctures of the prothorax arie not nearly so numerous, and there is no appearance of its being channelled : the breas: is chestnut. [Belongs to the genus Mclanotus.]

200. Crexiceres Krovaler firby--Plate ii., fig. 7. I.ength of body 7 lines. 1 single specimen taken in lat. $65^{\circ}$.

body blark. thicly plinctured; sloss obscured by inconspicuous hairs. Head with two impressions between the eyes; nose subemarginate: intemse shorter than the prothorax, scrated: prothorax longer than wide, channelled, posterior angles diverging, very acute, carinated: scutellum suboval, covered with white hairs : elytra rather wider than the prothoras, testaceous with a black discoidal blotch at the tip; slightly furrowed with punctures in the furrows: interstices punctured: legs piccous.

This specics, which is a icmale, is related to Ct. cuprews, but is much wider in proportion to its length. [Belongs to the genus Corymbit's latr. "One specimen found on the north shore of Iake Superior. Mr. Randall found it in Maine" (I.e Conte).]

[150.] 201. Elatre (Aphotistes) ARIPENsis Kirby--Length of body 6 lines. Several taken in Iat. $54^{\circ}$. Cumberland-house.

Body very liack, without hairs, underneath very minutely punctured. Head thickly and confuently punctured; nose with two slight impressions: antennæe shorter than the prothorax, third joint longer than the fourth : prothorax very thickly punctured, obsoletely channelled, longer than wide, rather narrowest before, sides curving, posterior angles acute, diverging, carinated: scutellum heart-shaped: elytra bronzed, or green-bronzed; furrowed, furrows punctured; interstices convex, minutely punctured; tips acute: a discoidal rufous spot or band, and sometimes two, marks the underside of the abdomen : legss piceous.

This species is the American representative of I: infressus, from which it differs principally in being smaller, narrower in proportion, with the head and prothorax not at all bronzed, and the latter more thickly punctured and without any glosis. [Not uncommon in Canada; "very abundant at Lake Superior; found by Randall in Maine" (Le Conte). Belongs to the genus Corymlites Latr.) 
FAMILI BUPRESTID.E.

[15I.] 202. BUPRESTIS (ANOPLIS) RUSTICORLM Kirby. - Length of body $9 \frac{1}{4}$ lines. A single specimen taken in Lat. $54^{\circ}$.

Body black-bronzed, punctured, glossy. Head with a levigated elevation in the centre between the eyes, channelled behind; marked with two yellow spots underneath on the cheeks, a triangular one adjoining the eyes on their inner side, and two dots of the same colour between them; prothorax grossiy punctured with levigated spaces, the discoidal one longitudinal; above the scutellum is an impression; sides converging at the base of the prothorax; anterior angles with a yellow stripe: elytra slightly furrowed with numerous very minute punctures in the furrows; rounded at the apex: interstices with scattered punctures; those of the second, third, fourth, fifth, eighth and ninth furrows elevated so as to form an obtuse ridge: the four last ventral segments of the abdomen have on each sice a reddish-yellow spot, those on the last segment being the largest and most irregular; anus with two distinct lateral teeth.

This species is so similar to $B$. rustica, that at first I regarded it as merely a variety, that insect however is smaller; the head has a distinct longitudinal channel: the prothorax is less thickly punctured, and the sides, at the base, converge less but more suddenly : the elytra are trun cated, or rather premorse, at the apex with a few minute denticles: the mandibles have a yellow spot, and there are none on the ventral segments of the abdomen, except the anal one : the anal teeth also are obsolete. rBelongs to the genus Ancylochira Esch. "Oregon and Washington Territories, abundant"(Le Conte).]

[152.] 203. Buprestis (ANoplis) Paganorum Kirby.-Length of body $73 / 4$ lines. A single specimen taken at Cunberland-house, Lat. $54^{\circ}$.

Very like the species last described. Body of the same colour, head, anterior angles of the prothorax, and underside of the abdomen similarly spotted, except that in the former there are no frontal dots. The prothorax however is differently shaped, being somewhat constricted anteriorly, with the sides towards the base rounded, it is also channelled; the sculpture of the elytra is similar, but they are more attenuated and truncated at the end, like $B$. A. rustica, and armed with three minute denticles. [Probably belongs also to Ancylochira; unknown to Dr. Le Conte.]

204. Buprestis (ANolits) Nutalli Kirly. - Length of body $7^{1 / 2}-8$ lines. Several specimens taken in Lat. $65^{\circ}$. and on the Rocky Mountains. 
This species appears to be related to $B$. octoguttata. Body black. bronzed, glossy, punctured; underneath with a few pale decumbent hairs. Head confluently punctured with several irregular connected levigated spaces; labial palpi, spou on the mandibles, labrum, lower margin of the eyes, and frontal spots, ycllow: prothorax bisinuate both at the apex and base, grossly punctured with several levigated spaces; lateral margin, except the base, and part of the anterior yellow; elytra slightly furrowed furrows punctured: interstices alternately convex and plane; the sutural one is convex and forked at the base; the flat ones are most punctured, but the con"ex ones more grossly; in the disk of the elytra are three equidistant irregular yellow spots arranged longitudinally, and nearer the base, on the second ridge, a line of confluent yellow dots; the apex of the elytra is truncated: [153] on each of the ventral segments of the abdomen the sides are narked with a triangular orange-coloured spot, those on the anal segment being larger and irregular; the coxæ also and underside of the thighs are partly of the same colour.

VARIETY B. Without the yellow line of confluent dots at the base of the elytra, and with the spots arranged longitudinally indistinct.

C. With all the ventral orange spots large and irregular.

D. Front with a large central spot. Base of the belly bluish.

E. Elytra with only yellow spots. Front as in $\mathrm{D}$.

F. With only one distinct yellow spot.

The most certain distinction of this varying species is the alternately convex and plane interstice of the furrows of the elytra. [Belongs to Ancylochira. " Lake Superior, one female." (Le Conte).]

205. Buprestis (ANoplis) lineata Fabr.-Length of body 9 lines. Taken in Nova Scotia by Capt. Hall.

Body above black-bronzed, underneath bronzed, punctured. Head below and mouth orange: mandibles black with a basilar orange spot; front obscurely banded and dotted with the same eolour; vertex channelled : prothorax dilated posteriorly ; anterior angles deep orange : elytra sligintly furrowed; furrows scarcely punctured; interstices flat, grossly punctured; truncated at the apex and armed with three minute teeth, one nearly obsolete; on each elytrum are two obscure deep orange stripes, the outer one diverging towards the base so as to pass below the shoulders, the inner one subinterrupted, widest towards the base, and not reaching the apex : fore-breast anteriorly orange. [Taken in Canada, but not com- 
mon. "Middle and Southern States, nor rare. Varies very much in the fulvous markings of the elytra, which are normally two broad vittæ upon each ; the extreme variation is where the outer vitta is broken into three spots, and the inner one into two; the two anterior spots are then connected by a transverse line forming a hamate spot. The tip of the abdo. men in the male is truncate, with a little tooth on each side; in the female, it is broadly rounded, but the same teeth are seen. The under surface is dull bronze, with the head and anterior margin of the posternum fulvous" (Le Conte, Am. Phil. Trans. xi., p. 206.) Belongs to Ancylochira.]

206. BUPRESTIS (ANoplis) FASCIATA Fabr.-Length of body $7-8$ lines. Taken in Canada by Dr. Bigsby; $\mathrm{B}$ and $\mathrm{C}$ in Nova Scotia by Capt. Hall.

[154.] Body of a luvely brilliant green, punctured underneath with a few pale hairs. Head confluently punctured : antennæ bronzed; vertex channelled: prothorax transverse marked before the middle with two transverse impressions, and another just above the scutellum; grossly punctured : elytra furrowed; furrows thickly punctured; interstices convex with fewer punctures : apex truncated with the angles terminating in a short point ; beyond the middle of the elytrum is a rather broad, especially: next the suture, wavy orange band surrounded by a dusky blotch ; beyond this and near the apex is another oblique abbreviated little band of the same colour.

VARIETY B. Smaller with the bands paler and narrower.

C. With only a singie band narrowest next the suture: prothorax without the anterior impressions. [Quite common in many parts of Canada, in al lits variations. We found it abundant at Credit, Ont., but quite rare at Cobourg and Port Hope. Le Conte (loc. cit.) states that it is " not rare, especially in the Northern portions of the Atlantic States; varies in colour from green to blue, and also in the size of the markings of the elytra. The tip of the abdomen of the $q$ is truncate in the $\hat{\sigma}$ it is truncate and bisinuate: the anterior tibia are simple." Belongs to Ancylochira.]

207. BUPRESTIS (STENURIS) DIVARICATa Say.-Length of body 10 lines. Taken in Canada by Dr. Bigsby ; I received both sexes also from Massachusetts by the kindness of Dr. Harris.

[155.] Body beiow copper-bronzed, above dusky-bronzed; glossy; confluently punctured and wrinkled. Head with numerous branching, levigated, narrow spaces : eyes yellow surrounded with a black orbit; 
mandibles black at the tip; front longitudinally impressed in the centre : prothorax with numerous levigated spaces, obsoletely channelled; sides anteriorly rounded with a slight sinus near the base ; basilar angles diverging : elytra very obsoletely furrowed, reticulated with numerous elevated lines, many scattered levigated spaces; bicarinated at the apex, the inner ridge being very short ; suture terminating in a point; at their truncated extremity the elytra are divaricated and suddenly attenuated: the first segment of the abdomen, and the breast bones are hollowed out into a longitudinal channel : prosternum linear. 「Exceedingly common in Canada; the larva bores into cherry and beech, and probably other trees. Belongs to the genus Dicera Esch.]

208. Buprestis (Stenuris) texebrosa fïby. - Length of body $73 / 4$ lines. Several taken in Lat. $65^{\circ}$, and in the Rocky Mountains.

Very like the species just described but much smaller. Body confluently punctured, upper surface black, with only the elevated parts glossy, lower bronzed-copper and glossy. Mouth and antennae bronzed; eyes black; front sculptured as in St. divaricata : prothorax uneven with shallow impressions and a broad dorsal channel; distinctiy bisinuate at the base; surface with levigated elevations : scutellum very minute, impressed : elytra divaricated and suddenly attenuated at the apex, which is rounded and has a single ridge; surface rough with many concatenated and levigated irregular elevations, side of the tip bronzed : breast channelled underneath, but the first segment of the abdomen less conspicuously, prosternum neirly an isosceles triangle: hypopygium with three short teeth. [Taken in Canada, but not very common ; "abundant at Lake Superior" (Le Conte). Belongs to Dicerca.」

209. [156.] Buprestis (STENuris) TENebrica Kirby.-Length of body $73 / 4-9$ lines. Several taken in Lat. $54^{\circ}$ and at Cumberland-house.

This species differs principally from St. tencbrosa, which in other respects it greatly resembles, in having the prothorax without any levigated elevations, and with the impressions, except the channel which is better defined, more obsolete. The : sytra are distinctiy furrowed, especially next the suture, with punctured iurrows, and there is only a series of levigated elevations near the lateral margin; the attenuated apex of the elytra is longer, rather truncated, and underncath of a dark blue : the prosternum is linear, and the base of the abdomen scarcely channelled: the teeth of the hypopygium are longer and of a brilliant ruddy-copper.

VARIETY B. Smaller, upper surface black-bronzed. [Probably synony- 
mous with Dicerca. lacistris Lec., a species taken at Point Kewenan, on Lake Superior.]

[157]. 210. BUPRESTIS (OdONTOMUS) TRINervia Kirby.-Plate ii,, fig. 9. - Length of the body $5 \frac{1}{3}-53 / 4$ lines. Several specimens taken in Lat. $54^{\circ}$ and $65^{\circ}$ and in the Rocky Mountains.

Body punctured, above black-bronzed, below copper-coloured and slossy. Head obscurely copper, confluently punctured and wrinkled, with a pair of levigated irregular eievations between the eyes; nose bilobed with divaricated lobes forming an obtusangular sinus; antennae copper with a testaccous pedicel: prothorax transverse, confluently punctured with several levigated spaces; lightly and widely impressed, impressions faintly gilled; disk channelled; sides very slightly emarginate ; base with a double sinus, scutellum triangular, acuminated: elytra with the depressed parts confluently punctured and very faintly gilded; with three subinterrupted longitudinal ridges connected by transverse levigated elevations; the two external ridges become confluent and proceed as a single ridge to the apex; lateral margin towards the apex minutely serrulate: back of the abdomen of a fine silky green : underside of the body thinly planted with hoary hairs; prosternum constricted in the middle and terminating towards the anus in a dilated trilobed point: shoulders much incrassated, armed below with a stout tooth; cubits clubbed at the apex ; four anterior tibiae bent or bowed: hypopygium bidentate. [Belongs to the genus Chrysobothris Esch. Taken in Canada, and, according to Dr. Le Conte, in the following localities: "Lake Superior, Lake Winnipeg, Oregon and Washington Territories." He states that "the colour beneath is somewhat variable, and that he has a $\hat{\delta}$ with the body cntirely green, and a $q$ in which it is coppery, with purple spots at the sides of the abdomen. The sides of the thorax are sometimes straight, sometimes rounded, but it is never obviously wider in front."]

211. BUPRESTIS (ODONTOMUS) Proxima Kirby.-Length of body $5 \frac{1}{2}$ lines. A single specimen taken in the Expedition.

[158.] Body minutely and thickly punctured : above black-bronzed obscure ; underneath cupreous with the gloss obscured; except near the anus, cloathed with numerous rather long decumbent hoary hairs. Head somewhat cupreous, hoary from decumbent hairs; nose green, bilobed with divaricated lobes, including a somewhat obtusangular sinus; antennae green; vertex channelled : prothorax emboṣsed in the disk, impressed and wrinkled at the sides; depressed parts punctured and reflecting a faint lustre of copper : scutellum an isosceles triangle, depressed and green 
at the base, elevated part black : elytra embossed, with a ridge extending from the apex where it is broader, by the side of the suture towards the base where it is abbreviated : the depressed-spaces have a faint lustre of copper and bronze, and are thickly punctured ; apex rounded and obsoletely serrulated : shoulders incrassated with a short roh!st tooth : all the tibiae are bent or bowed; cubit not dilated at the extremity : hypopygium with a deep sinus.

This nearly resembles $B$. O. trinervia, but is sufficienily distinguished by having only a single ridge on the elytra, and the posterior tibiae as well as the other pairs, bowed : the prothorax also is not channelled and its sides are rounded. [Belongs to Chrysobothris. Is not included in Le Conte's List.]

[159.] 212. Buprestis (Trachypteris) Drummondi Kirby.-Plate ii., fig. 8, var. B.-Length of body $43 / 4$ lines. Several specimens taken in Lat. $54^{\circ}$ and $65^{\circ}$ : and in the Rocky Mountains.

Body as it were reticulated with numerous punctures, bronzed, more oisscurely on the upper surface, more glossy on the lower. Head very thickly punctured, obsoletely and slenderly channelled; apex of the nose levigated : prothorax transverse, with a double sinus in the basilar margin; obsoletely channelled, inpressed on each side nearer the base, covered with innumerable scratches variously drawn, those of the disk being somewhat concentric; sides punctured: scutellum very minute, transverse : elytra very thickly punctured, and also exhibiting an appearance of granulations, slanting at the apex; the disk of the elytra, rearer the apex than the base, is marked with three yellow roundish dots arranged in an obtuse-angled triangle with the vertex towards the side : undersidc of the abdomen towards the anus less thickly punctured.

VAR1ETY B. Elytia with four yellow dots, a minute one, but varying in size, being placed outside the anterior one. [Belongs to Melanophila Esch. "Oregon and Washington Territories, abundant, straying into California and Alaska." (Le Conte).]

213. Buprestis (Trachypteris) vMBellatarum Fiabr.-Length of body $23 / 4$ lines. Several specimens taken near Cumberland-house, Lat. $54^{\circ}$.

[160.] The description that Fabricius and Olivier have given of $B$. umbellatarum is so extremely brief, that I am by no means certain that the insect I here give under that name is really synonymous with it. As far as their description goes it corresponds, and also with Olivier's figure, but that is very indistinct. It has been found in Barbary, Portugal, and Provence. Fabricius says it affords no characters except its colour and 
smooth elytra; but it will be found upon a close inspection, i speak with regard to the American specimens, to exhibit several.

Body black-bronzed, covered all over as it were with a fine net-work, produces by minute lines as, if scratched by a pin or needle; above dull, below glossy. Antennae much shorter than the prothorax: prothorax transverse with rounded sides, and longitudinal basilar impressions near each posterior angle: scutellum triangular: elytra with three very slight impressions arrarged longitudinally; an obsolete series of punctures runs parallel with the lateral margin; apex obtuse and very minutely scrated: prosternum acuminate.

2r4. BUPRESTIS (OXYPTERIS) APPENDICULATA Fubr.-Length of body $4 \frac{1}{4}-51 / 4$ lines. Several specimens in the Rocky Mountains, and near Cumberland-house.

[161.] Body black, not glossy. Head minutely and thickly punctured, channelled, on each side of the channel between the eyes is an impression; antennac nearly as long as the prothorax: prothorax scarcely wider than long, channelled, with a large but shallow impression on each side; sides thickly punctured so as to resemble net-work; rounded with the basilar angles depressed and a little diverging: scutellum nearly heart-shaped, acute : elytra rough with very minute and numerous granules, and several very slight shallow impressions, between which runs an obsolete obtuse ridge from the shoulder towards the apex, serrulated at the apex, and terminating in a very sharp point : breast minutely and thickly punctured; prosternum a little constricted in the middle, point triangular. [Though, as Le Conte remarks, this species here described is very closely related to the European insect to which it is referred by Kirby, it is Says' Melanophila longipes-a species not at all uncommon in Ontario, and taken also in such widely separated localities as Pennsylvania, Kansas and Lake Superior.]

215. Agrilus bivitratus Kirby.-Length of body 4 lines. Taken in Canada by Dr. Bigsby.

[Previously described as Buprestis (Agrilus) lilineatus Weber; for description vide Say's Ent. Works, r. 386 and ii. 596. This very pretty species is not uncommon in Canada, and is taken throughout the United States.]

[162.] 216. Trachys aurulexta Kirby.-Length of body 3 lines. Taken in Canada by Dr. Bigsby.

Body obovate, black-blue, glossy. Sinus of the head decper than in the other species; face nearly covered with glittering copper-coloured 
decumbent hairs; antennae shorter than the prothorax : prothorax transverse, repand on each side at the base with a central lobe, concave at the apex; anteriorly in the middle very convex; sides and base depressed; surface impunctured and tesselated with ruddy-copper hairs like those of the head: scutellum at the base transverse, with the vertex terminating in a long and sharp acumen : elytra with three ridges, the two inner ones less distinct, parallel, obtuse and abloreviated at each extremity, the external one distinct, acute running from the shoulder in an undulated line nearly to the apex of the elytrum; several rows of larger punctures are discernible, and sevcral spaces thickly punctured with minute ones; the elytra are also spotted with several hairy ruddy-copper spots, and ornamented with four ox five undulated hairy indistinct silver bands : underneath the tint of blue is very faint and the disk of the breast is bronzed ; the mesosternum is hollowed out into a deep channel. PPreviously described as Eiuprestis (Brachys) ovatea Weber. Rather rare in Canada; taken in the Eastern, Middle and Southern States.]

217 . Trachrs accducta Kirby-Length of body 4 lines. Taken by Capt. Hall in Nova Scotia.

[163.] Body oblong, punctured, hairy with scattered minute decumbent bristles resembling little scales, of a bronzed and glossy copper colour. Front with a slight sinus : prothorax transverse, trilobed at the base; disk longitudinally convex and naked; sides hairy; surface in the disk covered with minute transverse undulated lines curving upwards, and sides reticulated with them: scutellum transverse acuminated: elytra uneven, constricted before the middle, clouded and obsoletely banded towards the apex with minute whitish bristles; tips rounded, serrulate: prosternum broad, a litti: constricted in the middle, rounded at the apex.

\section{[164.] FAMILY PYTHIDE.}

218. Pytho Niger Kirby.-Plate vii., fig. 3.-Length of body $5 \frac{1}{4}-$ $51 / 2$ lines. Several taken in Lat. $54^{\circ}$, and in the journey from New York to Cumberland-house.

[165.] Body linear, depressed, black, shining, punctured. Head with a longitudinal impression on each side between the eyes; nose smooth, flat, with the internediate space less punctured; antennae and palpi dusky-rufous : prothorax conspicuously channelled, with the usual deep longitudinal impression on each side, lateral contour very convex, constricted posteriorly: elytra furrowed with elevated smooth interstices; furrows punctured and abbreviated at each end ; base of the elytra, where 
the furrows cease. punctured: bociy underneath minutely punctured; abdomen piccous ; tarsi rufous.

Var1etr $B$. Tilie aloo rufous: thighs piceous.

C. Bedy entirely ferruginous. It agrees with $A$ in sctilpure and every other respect except colour.

Many individuals of the present species were taken in th Expectition, all of then agreeing in having wo tint of blue in the elytra ; in having the levigated part of the base muctured, and the sides of the prothorax more prominent, than in $P$. acferessus, fron: which it secms cleariy distinet. IIncluded in the list of Canadiar Colcoptera. Taken on the North shore of Iake Superior by Agasiz's Expedition.]

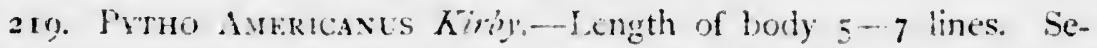
veral taken in 1 alt. $54^{\circ}$, and in the journey from New York to Cumberland-house.

This speries difers from the preceding chidly in having the ablomen, medipertus. postpectus, legs and month notons ; in a slight punctured elevition on each side of the nose; the space between the ejes:llso is nore distincty punctured, and there are two deep inyressions und the head letween the eyes; the proborax is widest anterioriy, and not corstricted behind: and the elytra are dee blue, and soarcely punctured at the base.

It differs from $P$. aepessus. in being wider in proportion to its length, and in having the abdomen, and two posterior sections of the breast, invariably rufous.

VARIETY B. Flytra rutous at the sides and tip.

C. Elytra entireiy rufous.

J. Elytra entirdy rutous ; lead and prothorax piceous.

L. Hody entirely rufous. [Taken in varicus parts of Canada.]

[166.] FAMII.Y TKOGOSITIDE.

220. 'TRngosma Americana Kirly.--1ength of body 5 lines. Two specimens taken in the journey between New York and Cumberlundhouse.

This species is the Anerican representative of T. caraboicies from which it principally differs in being larger, with the frontal impressions more distinct ; the stalk of the antenna much slenderer, and the knob thicker : the prothorax not so narrow and constricted at the base, and the elytra slightiy furrowed. ["The description of this species is so imperfect that it cannot be identified" (Le Conte)]. 


\section{[167.] FAMIIY CERAMBYCID.F.}

221. MONocuamtis RRSLTOR Kirly.-Length of body $10 \frac{2}{4}$ lines. Frequently taken in lat. $6,5^{\circ}$.

[Sivnonymous with $1 / 0$ ohummus scutellatus Say-i) very abundant species in many parts of Cinadia. Fur description of this well-known insect, aidt Sily's lint. Works, 1. 192.]

[168.] 222. Monochasus coNfusor Kirby.--I.ength of the body $r$ inch and $r \frac{3}{4}$ lines. Taken in Nova Scotia by Mr. Mar Culloch, in Canada by Wr. Kigghy, in Massachusetts by Mr. Drake.

body linear, elongate, black, covered with white or cinereous decumbent hairs, but so as to let the black appear in confused spots and reticulations. Inbrum rather long, fringed anteriorly with furmginnu hairs; maxiliary galyi long; rhinarium hroad, rufous; antenne testaceous with the redness obscured by decumbent cinerous hairs, but the scape and pediecl are black; the anteme of the female are something longer than the body: those of the male are twice its length : the spines of the prothorax are stout, covered thichly with white hairs, and dotted posteriorly with black ; in the disk is a central oblong impression : scutellum thickly covered with white decumbent hairs, with a black longitudinal line: the ground colour of the elytra is testacesous which is more or less obscured and clouded by white decumbent hairs, besides there are several hlack dots and oblong spots produced by erect hairs; at the base of the elytra, especially on the projecting shoulders, are numerous round clevated smooth little spaces, and their whole surace is covered with scattered minute punctures.

N. B.-.-In the male the black spots and dots of the elytra are fainter, and sometimes nearly obliterated. [The synonyms of this species are so much confused that Kirby's specific name may certainly be considered a most appropriate one, if it is allowed to stand. The insect here described is appirently identical with Monohammus notalus Drury, and $M$. titillator Harris; according to the rules of priority, it should, therefore, have the former name. It is a very common species in the pine forests of this country, especially in timber that has been left standing after a tire has run through the woods. Specimens of this beetle are often found in recently built houses and about himber-yards.]

[r69.] 223. Monochamus marmorator Kirly.-Length of body is lines. A single specimen taken in Lat. $54^{\circ}$.

Body black, covered underneath, but so that the black appears in various places, with subcinereous, or somewhat tawny decumbent hairs. 
Head and prothorax covered in the same way but with redder hairs : spines of the prothorax very robust. rather long, sharpish: scutellum covered with a coat of cinereous hairs, divided by a black longitudinal line: elytra black, marbled variously with cincreous and reddish tawny hairs; the cinereous spots are dotted with black; the surface of the elytra when laid bare appears punctured, and at the base are several conflucut smooth elevated spaces ; suture and lateral margin testaceous ; apex acute.

N. B.- The anternice in the specimen are broken off. [Unknown to us.]

224. Aranthocrives (Cikaphisurus) pesildes Kirly.-Iength of body $41 / 4$ lines. A single specimen taken in the journey from New York to Cumberlani-house.

[ 170.$]$ This species is one of the most minute of the Capricorn tribes. lody linear, black but covered with a coat of whitish decumbent hairs, which appears more or less sprinkled with black dots. Head longitudinally channelled; antenne mutilated in the specimen. but those joints that remain are white at the hase: prothorax short, armed on cach side, towards the base with a short sharp spine, panctured with scattered punctures ; elytri punctured especially towards the base, mottled and speckled with brown, with an eblig!te brown band a little beyond the middle, apex of the elytra rounded : podex and hypopyium, or last dorsal and ventral segments of the abdomen elongated, so as to defend the base of the ovipositor which is exserted, causing the insect to appear as if it had a tail ; the hypopygium is emarginate: thighs much incrasiated at the apex. [Not common; taken at Grimsly by Mr. Pettit, and on oak-trees in the neighbourhood of Philadelphia by Mr. Bland.]

225. Callimum agreste Kirby.-Length of body it lines. Several specimens taken in the Expedition, and likewise in Nova Scotia by Dr. Mac Culloch and Capt. Hall.

I at first took this for a variety of $C$. rusticum, but on a closer inspection I found it differed in the sculpture as well as colour; and having received a specimen of that insect from Dr. Harris, in which its characters were all preserved, I am induced to descr be $C$. agresie as a distinct species.

It differs from $C$. rusticum in being smaller, of a darker brown, without a tint of red; and in having more gloss. The prothorax has three deep round inipressions, while in the insect last named, the impressions are slight, and the two anterior ones oblong: the elevated lines of the 
elytra are more prominent and hecome visibly confluent towards the apex, where they form several reticulations : the underside of the body is much more thickly covered with hairs, which are hoary instead of yellowish, those on the breast being longer than those on the abdomen. In other respcts these two insects resemble each other. [Included in the genus Criocephalus Muls. Taken throughout Ontario and at Lake Superior.]

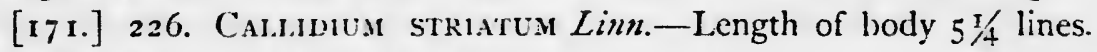
A single specimen taken in Lat. $65^{\circ}$.

Body linear, black, thickly punctured, underneath with a few hairs, glossy; alove without any hairs or gloss. Antennæe a little longer than the prothorax: prothorax suborbicular, covered thickly with minute granules, with an elevated tubercle in its disk: elytra most minutely and thickly granulated, with four longitudinal slight furrows occupying the half adjoining the suture, the alternate interstices being most elevated: tarsi rufo-piceous. [Synonymous with . Ascmum mestum Hald. Iaken throughout Ontario.]

227. Callidium corlake Kirby.-Length of body 5 lines. A single specimen taken in Lat. $54^{\circ}$.

Body linear, black, hairy with whitish scattered hairs. Head thickly punctured; antenne shorter than the body, rather hairy, piceous, scape black: prothorax rufous, with a few scattered punctures, glossy, projecting on each side into an angle or short spine : elytra very thickly and confiuently punctured : body underneath glossy, slightly punctured : anterior part of antepectus rufous : tarsi piccous, first joint of neariy equal length in all the legrs. [North Shore of Lake Superior, Agassiz's lixpedition.]

[172.] 228. Callidium Protevs Kirby.-Plate v., fig. 5.-Length of body $5-8,2$ lines. Taken abundantly especially in Lat. $65^{\prime}$.

body black, mimutely punctured, hairy with longish hoary hairs, especially underncath. Nose with a deeply ploughed transverse furrow ; front behind the antennx violet, confluently punctured; palpi black, maxillary rather long, last joint an obtusangular triangle; antenna longer than the prothorax; sides of the prothorax very rough with deep confluent punctures: elytra wrinkled, violet, with three longitudinal, subinterrupted, callous, pale lines, of which the intermediate one is the longest, and the external one the shortest: legs piceous, with the incrassated part of the thighs testaceons.

This species varies extremely both in size and colour. The following are the principal varieties:-

VARIETy B. Head and prothorax violet; elytra lurid with only two callous lines. Length $6 / 4$ lines. 
(.) Head, except at the lase of the antemne, black: sides of the prothoras : ienct. disk bronzed: elytra as in the list. length 5 lines.

1). Hatd and prothoral black: elytra inriel: lines faintly matket. Length $5,:-;$ lines.

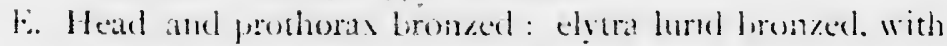
two distine lines. length $60-7$ lines.

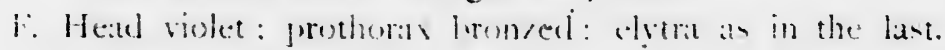
l.ength 6 lines.

(i. like the last. lue the cillous lines of the elyara are oluontere. length $5 !:=61$ lines.

1. Head and prothora hat $k$ : chirat hrid with there line length $; !: 2$ lines.

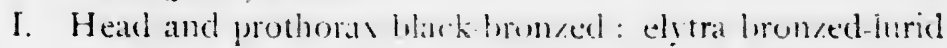
with two line:s.

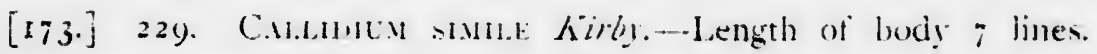
A single specimen taken with the preceding species.

This species in most respects is so like $C$. M. Protus, that I had set it by as another variety: but upon firther cunsideration 1 am induced te. sive it as distinct. since it difiers not onl in colour but in the form and atulpture of the prothorax and oilier parts.

The apex of the palpe is more dilated, so tials it in strictily securiform: the tront behind the antemnate is clevated and gibbons, with few scattered functures: the sides of the prothoral ale more puffed oute and much more minutely and thickly pumetured, and there is a pair of impressions in the dist : the antennate also at the biane are rufous: in other respects it cloes not difter from . K. Imitits.

L'This species. together with the preseding and the sulseguent one.

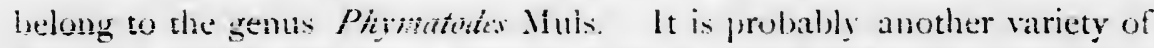

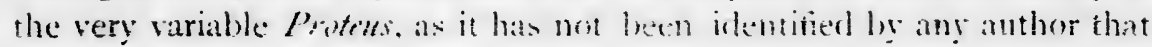
"le are aware of.]

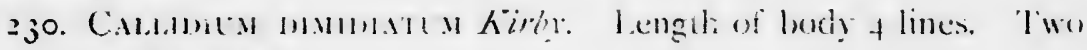
specimens in $\mathrm{I}^{\mathrm{t}} \mathrm{t} .5 \mathrm{t}^{5}$.

Body not glossy: impunctured: hat! underneath : and except the forcbreast, which is black of a dull rufous. Head channelled between the eyes, behind them convex : antennate rufous. shorter than the body: prothorax somewhat coarctate at the base: minute?y granuated: oinsoletely. shannelled, more conspicuousily behind : elytra rufous anteriorly.

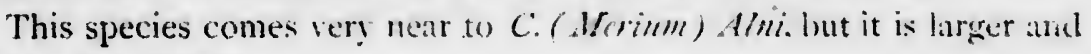
has no whitie hands. 


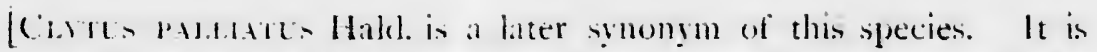
taken in Canada and the Fastem States: also on morth shore of Iake superior by Agassiz's fivedition.]

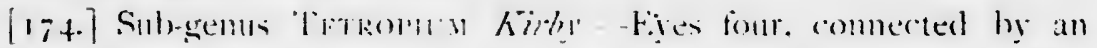

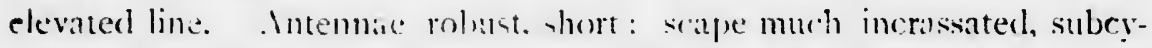
linclrical, remaining joints subclavated. P'rothorais constricted anteriorly and posteriorly. Thighs much incrasiated. sometimes chubled.

The type of this subgenus is Collditum tristi fahr. tor those with clavated thighs. and $C$. abilom, for those in which they are incrassated nearly their whole lengh. These inserts will he fomd whane four dislinct eyes separated ly the substance of the head elevated into a ridge. which at first sight appears a continuation of the eye hut which evidently has no lenses implanted in it they are also distinguished hy their robust and short antemnate.

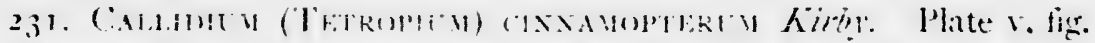

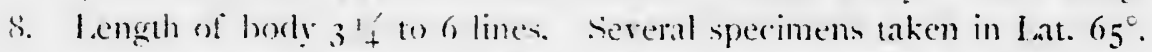
At first sight this species sesms the exact comnterpari of Callitiun trate, which it resembles in almost every respect : lout upon examination it will be found that the thighs of these two insects are of a very different shape. those of $($. \% triste being much attenuated at the hase, while those of $C$. T. ammomptomm are not at all. In the latter also the sides of the fore-breast are red, and the elytria are comsiderahls darber. very near the rolour of rimmamon.

The American seremens rary mech in size. bitt all agree in the shape wi the thighs.

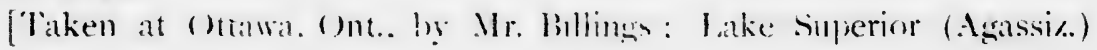
Sint common. $\mid$

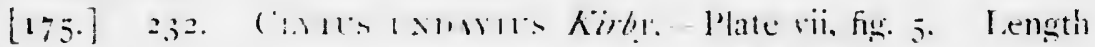
whody 8 lines. Pwo specimens taken in lat. 54.65.

Body black. undemeath hoary from decmmbent hairs, above velvetty. Head anter: hairy with whitish hairs. hehind the antemnae very thickly punctured : jalpi. labrum, lip of the nose and checks, eyes. antemuae, and subface rufous : prothorax rough with rery minute and numerous granules. the base and aper have an interrupted hand of yellow hairs. and a hoary spot on each side produced by hairs: scutellum elark hown: elytra with an oblicuc linelet adjoining the scutellum, another in the dish near the base, two way hands. the extremitic of the anteriof one pointing towards the base, and of the posterior one towarus the apex: the apex and suture, all pale yellow. produced hy decumbent hairs : underneath on each side of the breast are three spots of the same rolour. as likewise is the 


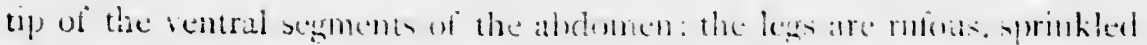
with hoatry hairs.

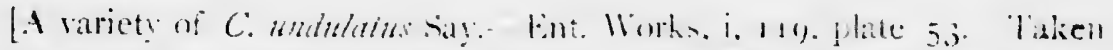

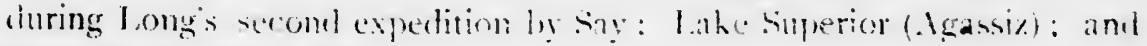
throughout ('anatil II cost.?

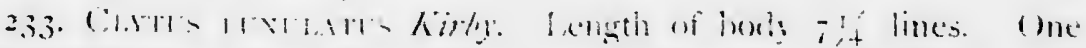

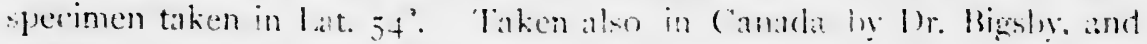
in Nora Sicotia di: (ap) Mall.

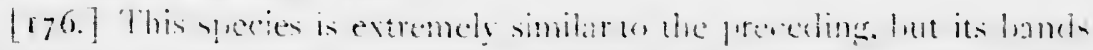

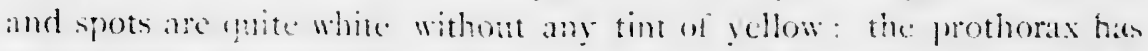

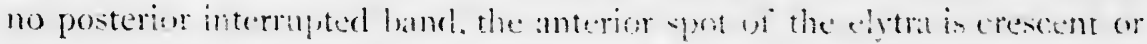

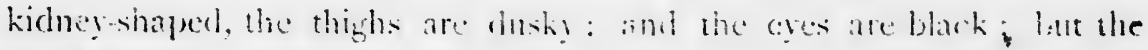
most striking distinction in cahblited ly the head. which is perfert! smooth and withent punctures. but when the areiptut is disengaged trom the prothoras, as it is wels the head is inclined romards. the front wibl be

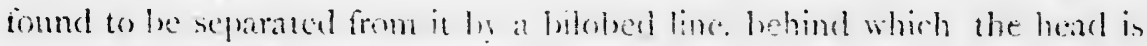
thickly and comthently penctured.

[Poblably a varery of the preeching spesies.]

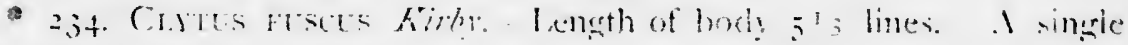
specimen taken in T.at. 5.t?

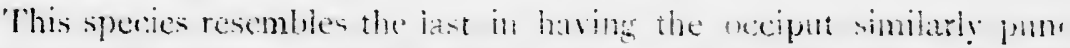
tured, and the markings of the elythare similar. cercegt that instead of the white streat at the hase there in omly a dot: but it in of a brows colour, with the hearl and pombuax nearly blach : the fombe is distinct!y granulated: the palpi, labmun. eyes, and antemnate are rufous, as in 6 : whdatus, and like that the prothorax ha both an anterior and posterior intermpted band of whice hairs: the elytra and underside of the body are reddish-brown : the legs neforis. posterior ones very lons.

TTaken at (Ottawa and other jolares in Omario.]

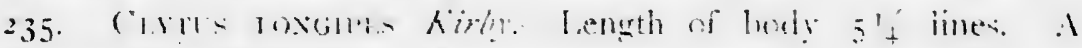
single specimen taken in lat $54^{\circ}$.

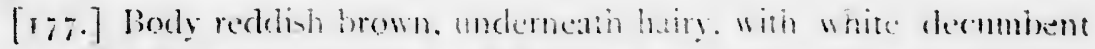
hairs. Hearl blark, mimmely ams thickl! punctures, with a longrturlina!

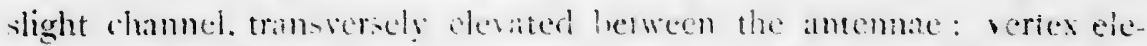
bated: palpi, labrum. ancennu and extendy of the mose. rufous: prothoras black, nather oblong. elerated longiturlinally in the diak with 1 anterior bowed tamsverse ridge. followed ly several mimute acute tuberres. next in the middle in another shorter ridge. which is also succeeded by simitar mbercles: the siles of the prothorax ars mainlated : between the granulated portion and elevaled lisk, it is minnely reticnlared. with a 


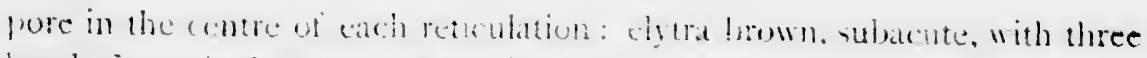
hands formed at decumbert white have the het forming a crescent at

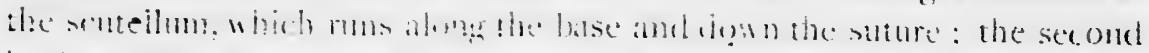

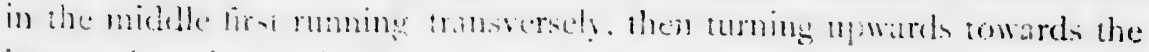

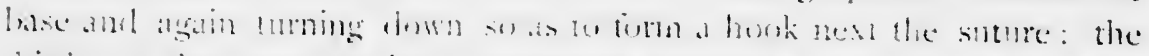

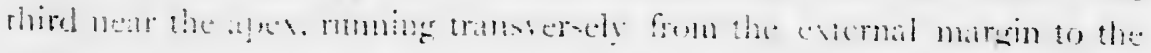

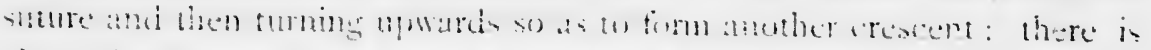

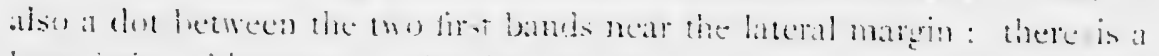

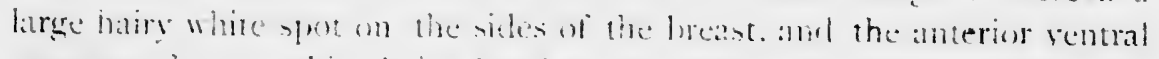

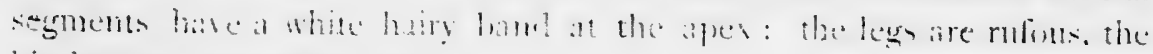
hinder jour remathahly lung.

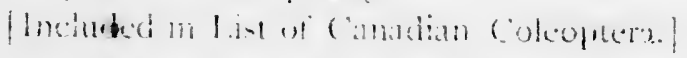

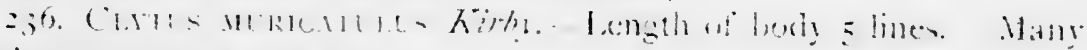
irecimens taken in lat 5 :

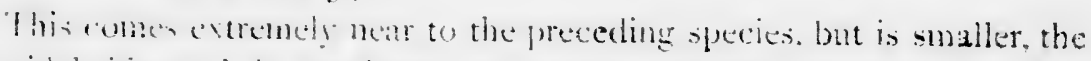
diseodal riges of the wruhoras are nearly obsolete, that part has four whe hariog spents. the bands of the clytra are difterently shaped, and the

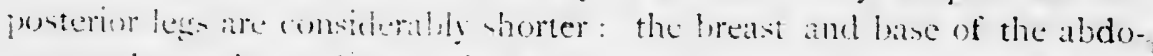

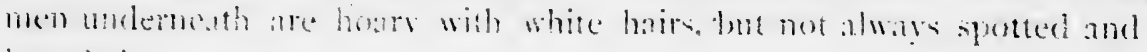
liranderl.

[Han meteren ielentifed ato al dintimet spertes.]

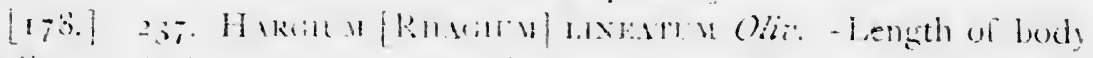

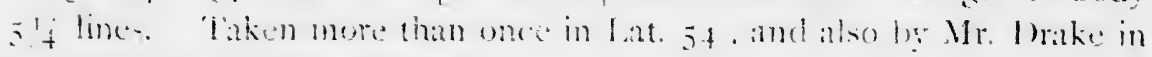

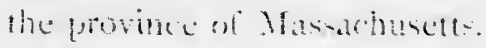

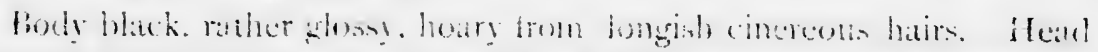

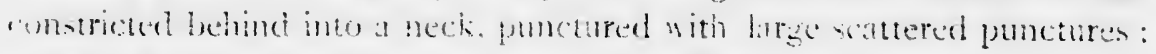
abtennate shorter that the prothorat, robstst. lat joint orate pedicel tostaceous: frothoras somstriced anteriorly and poteriorly, armed on each

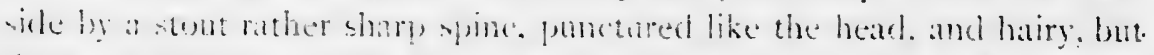
there are three longitudinat sripse wihout hats, and the intemediate one

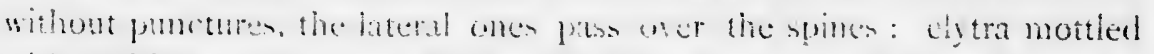
with whisish or anceoms hatrs. with three longitulina! ridges, the two extemail ones contluent near the anes, and a litte higher tip including ietween lhem a hort ablereilites ridge: lhe interstices are puncturer! like the head and prothoras : at the base and lateral margin the elytrd are reddish, and on the ridge next the suture there are allo gellowish spots: coxate, troxhanters. and batse of the thigh redash: abclonen earinated imderncath.

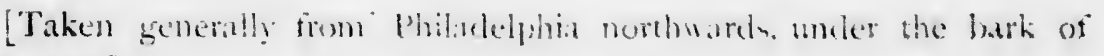
pine trees. 
238. Pachyta Liturata Kirby:- - Length of body 7-9 lines. Several specimens taken in I.at. $54^{\circ}$ and $65^{\circ}$.

[179.] This is the American representative of I'. guadimaculata, Iron which it differs principally in being not so hairy, with hoary instead of yellow-tinted hairs: the punctures of the prothoras and elytra are nore minute; the antennace are ratiner shorter, and the elytra, instead of two subquadrangular black spots, have three less black linear ones, the wo, anterior ones being parily parallel, and in some specimens confluent.

$$
\text { CiNLY I.FTLKA. I.inn. }
$$

This genus may be thus subrivided with respect to the species about to be described.

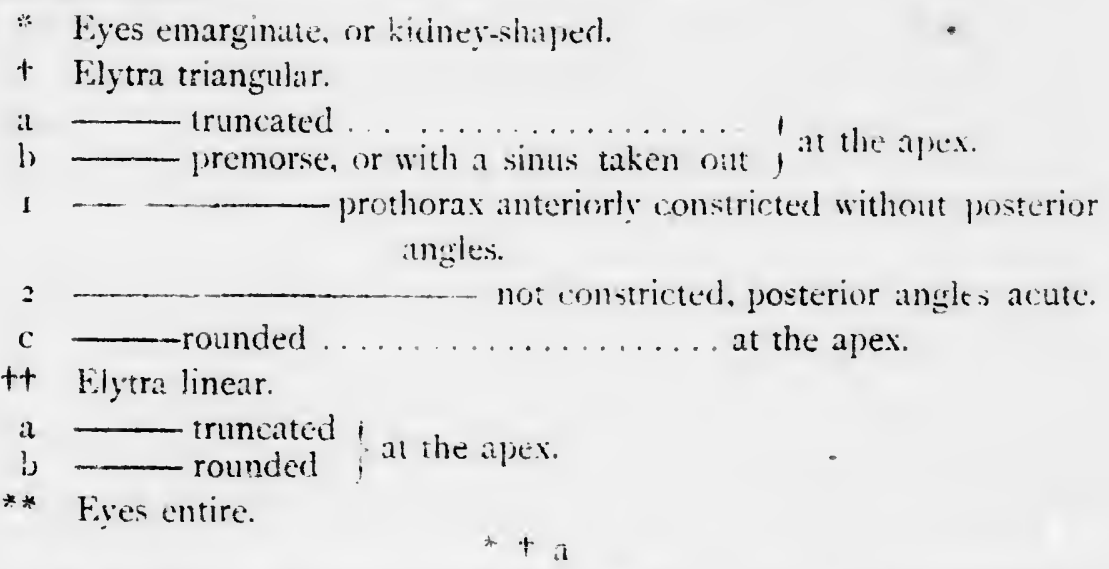

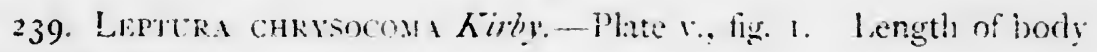
$5 / 2-6 / 4$ lines.

Several specimens taken ; the largest, in the journey from New York: the smaller, near Cumberland-house. Taken likewise by Mr. MacCulloch and Capt. Hall, in Nova Scotia.

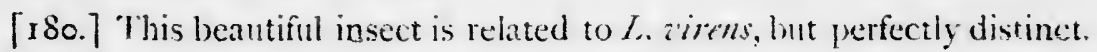
The body appears to be black, but that colour is, in most parts, nearly concealed by a thick and mostly long coat of brilliant goiden hairs with a rery slight tint of green, where the coat is thin the body appears minutely punctured. Head subelongated, the neck exserted. subtriangular: nose with only a few scattered whitish hairs; antenne black, third, fourth, and fifth joints rather slenderer and longer than the succeed. ing ones: prothorax between globose and bell-shaped, constricted anteriorly, channelled, grossly punctured: substance of the elytra pale testaceous, towards the apex externally they are dusky; the golden down on 
them is shorter and decumbent : apex diverging and obliquely truncated : underside of the ahdomen particularly brilliani from decumbent hairs: legs less hairy than the rest of the bod!. [Taken from New York to Lake superior, but not common. Yore frepuently taken in the neighbourhood of (2uetece.)

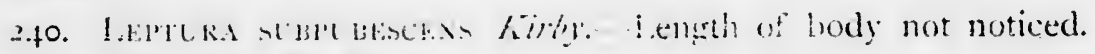
l'ahen in Canada by l)r. Bigsby.

Boly llack, thinly coated with yellow hairs. Head and neck grosily punctured : ateme longer than the prothoras, black, downy. internediate joints rather sicnderer than the others, fouth shorter than

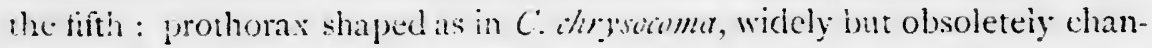
nelled: rough and reticulated, as it were, with numerous confluent punciures, sides more hairy than the disk: elytra thickly punctured, pale iestaceous, blach at the apex, where the suture eurves outwards so that they diverge from each other, extremity neirly transwersely truncated: abciomen underneath minutely, hreast rather grossly, phonctured: podex suinemarginate.

$$
\therefore+b 1 \text {. }
$$

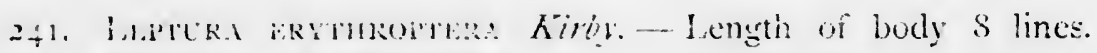
Taken in Nova Scotia by Capt. Hall!.

[s s.] body very black, slighty doung, undemeath minutely punetired. Head shorter tham in the last section, as well as the nect bsoletely channelled: thick!y but not mimutely punctured; antenna ruther longer than the prothoris: third and fourth joints a litte slenderer that the others, and pale red at the base; the sixth is pale with a lilack yet on eatch side at the apex : and the whole of the eighth is of the same colour; the last joint is acuminated : the prothorax is constricted anterforly, and the constricted part is perfectly smooth, the rest is thickly and confhently punctured and wrinkled: at the base the prothorax is ecpressed and obsoletely tribobel: scutellam black. representing an isosceles triangle elytra of a dall red. grossly and deeply punctured: extremity scooped out with the external angle longer than the internal and acuminate: mesosternum emarginate posteriorly. Traken in Canadi on flowers in July ; not common.]

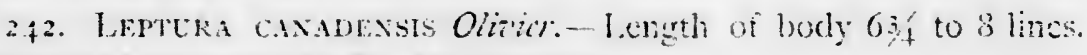
Taken in Nora Scotia by Dr. MacCullock.

body rery black, slightly downy, minutely punctured. Head as in the last species, but the neck is not channeled: antenna with base of tine fifth joint, the whole of the sixth and eighth, except the black apex of 
the former, pale or pale rufous: prothorax as in L. crythroptera, only deeply and confiuently punctured but not wrinkled: elytra black, sangruneous at the hase. In other respects this species resembles that insect; the external angle of the apes of the elytra is however shorter. [Quite common from (ieorgia to lake Superior.]

$$
* 1,2 .
$$

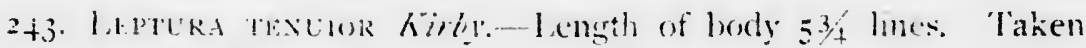
in Cinada by lor. Bigshy.

[182.] body ilask, ratier sender, slighty punctured, thinly coated with decumbent yelow hairs. Intenna shorter than the body, fifth joint scarcely longer than the fouth : prothoras letween bell-shaped and a trmeated conte, it little constricted in the miclle. fringed with yellow hairs anteriorly and postoriorly : scutelimm triangular: elytra testaceons, yellow at the basc. an ' with three yellow hands, the first interrupted; oblique sinus at the apea not so deep as in the two preceding species: legs testaceous: abiomen of a deeper colvur; and segments scarcely emarginate. This necetes differs in habit from the two preceding ones, it is narrower in proportion, and comes nearer to /. flutdrifasciata, but the posterior angles of the proihorax, though arute, are not so prominent; it belongs however to the same subdivision. with the last mentioncd insect. [Consirlered isy. Xewmen to be synonmous with Stransalit fustax.]

$$
*+c \text {. }
$$

24. LAMTRA bRats Kirly.- Length of lody 5 lines. Taken in ( anada by Lr. Higsby:

Body shorter than ustial in proportion w its with ; black, underneath minutely punctured and thing covered with rather silvery decumbent hairs. Fead thiely and confliculy punctured, rather downy with erect hoary hairs : antenne shoiter than the body : fourth, fifth, and sixth joints bung and slenderer than the resi: sic hast fhort and pale at the base: prothorax between bell-shaped and giobose, deeply and confluently punctured : down: with some erect houry hairs anteriorly constricted, posteriorly depressed: scutellum linear corered with pale decumbent hairs: elytra very grossly and deeply punctured. shorter than the abdomen and rounded at the apex, with a lateral band bent a litte inwards towards the base. which it does not reach, of the colour of the yolk of an egg : anus

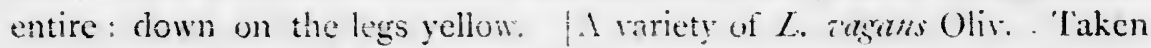
in Canada, also in . . Y. and Peñ.]

245. LePTCR. SEXMACLLAT Liml - Length of body $5 \%$ lines. Two specimens taken in Lat. $65^{\circ}$. 
[183.] Body rather short, black, downy, minutely punctured. Head very thickly and minutely punctured, obsoletely channelled; antennæ slender, shorter than the body, fifth joint considerably longer than the fourth : prothorax shajed as in the preceding species but less depressed posteriorly; very thickly as well as minutely punctured : scutellum triangular: elytral pale-yellow, with an arched black spot at the base, then follows an interrupted band consisting of three acute black spots placed in a triangle, beyond the middle is a dentated black band which reaches neither the suture nor the lateral margin; the apex also, the suture, and the lateral margin towards the apex, are all black.

VARIFTY B. Head not channelled: spot at the base of the elytra coalescing with the intermediate and lateral oncs of the anterior band, and reaching the lateral margin; interior spot reaching the suture so as to form the half of a spot common to both elytra : the intermediate band is broader and reaches both the suture and lateral margin. [Belongs to Strangalia (Pachyta). Taken at Quelece by Mr. Couper: Lake Superior by Agassiz's Expedition.]

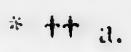

246. Leptlra semivittata Kirbl:- - I,ength of body 6 lines. Taken in Canada by Dr. Bigsby:

Body long and narrow, black, underneath slightly and minutely punctured, with the sides of the breast and abdomen brilliant with a silvery lustre from decumbent silky hairs, above glossy and almost naked. Head thickly punctured, but behind each eye there is a levigated space: antennæ longer than the prothoras, intermediate joints not slenderer than the others, the fourth as long as the fifth; neck short and levigated: prothorax bell-shaped, not constricted anteriorly, depressed posterioriy : thinly punctured, especially in the disk: scutellum triangular: elytra punctured but not thickly, punctures almost arranged in rows, towards the apex they are very slight : a reddish-yellow subflexuose stripe runs from the middle of the base of the elytra a little more than half way towards the apex, which is diverging and truncated : the ventral segments of the abdomen terminate in a reddish membrane. [Synonymons with L. vittata Oliv.; common in Canadia on flowers during June and July: taken from Alabama northwards.]

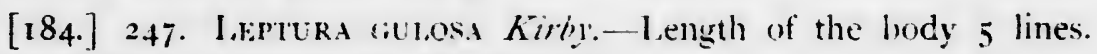
Taken in Nova Scotia by Dr. MacCulloch.

Very nearly related to the preceding species, from which it differs chiefly in being much smaller, in having the underside of the body more 
thickly covered with hairs glittering like silver; in having the throat pale red; the fith joint of the antenne longer than the fourth; the punctures of the elytra more numerous and scattered; the yellow stripe rumning nearer to the apex of the elytra, dilated at the base and not flextiose: the fore-breast also in the dish, the after-breast on each side, and the base of the thighs are obscureiy red : the tibie are piceons.

$$
*+i
$$

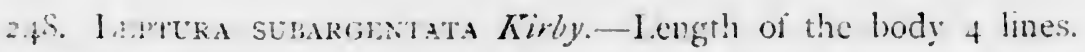
Tirien in 1 at. $65^{\circ}$.

body narrow, encirely black, very minutely and thickly punctured. underneath glittcring. lut less consricuously with silver pile; antennec: shorter than the body, nearly filiform, fourth and fifth joints of equal length; prothorax perfectly bell-shaped. anteriorly not constricted, posterior angles acute, divergingr and covered with silver jiile: elyira rounded at the apes. [Taken in Canada and Lake Superior.]

[185.] 249. Leirerk simus Kirby.--I.ength of body $3^{1 / 3}$ ines. A single specineñ taken in Lat. $65^{\circ}$.

'inhis may possibly be the other sex of the preceding species which it resembles in ciery respect, except that the antenna are rather longer, the scape or first joint, all but the base on the lipper side, is rufous, as are likewise the thighs and four anterior tibix: the posterion thighs are however black at the apex.

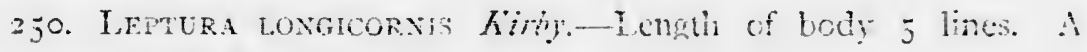
single sperimen taken in lat. $65^{\circ}$.

At first sight this siccies a good deal resembles $L$. semiatitat and glates of the former section, but iis eyes are entire, and its antenne muci slenderer and of a different type, more nearly reseinbling those of L. argentata and similis. Body black, minutely punctured, downy, especially underneath, with silvery hairs. Ilead minutely, thickly, and confuently punctured; homm and base of the mandibies rufous; last joint of the palpi securiform; antennae very slender nearly as long as the body; scane incrassated, rufous, black at the base: prothorax a little constricted anteriorly, very thickly junctured with a longitudinal dorsal impuncture line or chinnel : scutelim longitudinally cor ave, rounded at the apex; elytra nearly linear, grossly punctured, glossy, nearly black, with a pale stripe extending from the middle of the base to near the apex, and gradually approaching the suture; apex subtruncated: legs rufous at the base. [Belongs to the genus Acmarofs Lec.] 
[186.] 251. T.F.PTuks Proteus Kirby.-Iength of body $3 / 4-5 \%$ lines. Taken abundantly in Lat. $54^{\circ}$ and $65^{\circ}$.

Body narrow, blac's, punctured, somewhat glossy, rather hairy, especially underneath, with decumbent hairs, those on the elytra have somewhat of a golden lustre, the rest are silvery. Nose more grossly punctured than 'the rest of the head; vertex convex; eyes subovate, pale with a slight golden lustre; antennae filiform, longer than the prothorax, obscurely rufous, with the four first joints black, fifth joint longer than the fourth : prothorax campanulate, anteriorly constricted, posterior angles a little diverging, thinly punctured; channelled, the channel running between two dorsal gibbosities: scutellum triangular: elytra rather widest at the base, and punctured there more grossly next the suttre ; diverging and truncated at the apex: tibiae piceous or rufo-piceous; four posterior thighs rufous at the base.

VARIETY B. In this variety only the base of the six last joints of the antennae is rufous, all the thighs are rufous at the base, and the tibiae of a clearer red, but they are dusky at the apex; tarsi rufous at the base. Length of the body $33 / 4$ lines.

C. Hlytra with a stripe at the base, tips and lateral margin rufous : antennac entirely black : legs as in variety $B$. Length of the body $4 \% \frac{2}{4}$ lines.

i). Elytra with a longitudinal rufous stripe dilated at the base and apex; bead of the lateral margin also rufous; antennae and legs nearly as in $\mathrm{B}$, but the whole of the tarsi is obscurely rufous. Length of the body 3-4 lines.

k. Elytra rufous with the stiture and a stripe near the margin abbreviated at both ends, dusky : antennae as in $\mathrm{A}$; legs as in $\mathrm{B}$. Length of the body $4-5$ lines.

F. Elytra rufous, with a dusky suture; antennae as in $\mathrm{A}$; legs as in $\mathrm{D}$.

G. Like F, but eiytra luteous; antennae all black. Length of the body 4 lines.

H. Like F and G, but legs and aniennae black. Length of the body $33 / 4$ lines.

L. Proteus seems to vary ad infinitum in the colour of the elytra, antennae, and legs, but as all the varieties agree in every respect except 
coiour and size, and the elytra advance so gradualiy from pale rufous to black, or vice versa, there can be little doubt of the identity of the different varieties. [This very variable species is common thronghout Canada. It belongs to the genus Acmacos Lec.]

[187.] 252. Lrirtuka LoxGicles kirly.-Length of body 4 lines. Several specimens taken in Lat. $54^{\circ}$ and $65^{\circ}$.

like the preccding speries but shorter in proportion with a longer head. Body black, punctured, hoary with rather silvery down: head as long or longer than the prothorax; cyes pale, subtriangular; antennae with the second, third and fourth joints slenderer than the rest : prothorax shaped as in L. Proteus, constricted before, depressed behind, but without diverging angles, channelled but with no gibbosity on each side the channcl : elytra nearly linear, very thickly punctured, dirty-yellow, with a dusky lateral blotch extending from the base beyond the middle of the elytrum, suture and subtruncated apex black; down yellowish. [Belongs to Acmeops Lec.]

\section{F.ND OF CERAMBYCIDF。}

[190.] 253. Axomium fovestum Kirby.-Length of body 2 lines. A pair taken in Lat. $65^{3}$.

This species very closely resembles $A$. striatum, of which it may be regarded as the American representative. It differs principally in having a rather large excavation in the middle of the elevated back of the prothorax, the sides of which are armed with a triangular tooth or prominence.

The male is obscurely rufous, both above and below, the female is browner alove. [Taken in Canada by Mr. Billings. Belongs to the genus Hadrobregmus.]

254. C1s Micavs Fabr.-l length ố body $x$ line. Two specimens taken in the Expedition.

Body subcylindrical, black-brown, glossy, with numerous short upright pale rather glittering hairs; minutely bui not very visibly punctured. Head rather flat and lacunose ; antennae and legs testaceous. Prothorax antericrly sinuated on each side with the niddle lobe rounded and projecting a little over the head; sides slenderly margined; posterior angles rounded. Punctures of the elytra seem almost, but very indistinctly, arranged in rows.

\section{[Ygr.] FAMILY SCOLYTIDE.}

255. Tomicus PINI Say.-Length of body $13 / 4-2$ lines. Frequently taken in the journey from New York to Cumberland-house, and also in Lat. $65^{\circ}$. 
Brdy cylindrical, deep chestnut, glossy, hairy underneath. Head above with scattered granules; nose fringed with yellowish hairs; antennæe testaceous : prothorax rather oblong, angles rounded, anteriorly granulated with minute elevations, posteriorly punctured with scattered punctures, hairy next the head and on the sides : elytra hairy on the side, with five rows of transverse punctures next the suture, which reach onl; to the truncated part ; punctures of the side and apex scattered; apex truncated cbliquely and excavated, with the external edge of the excavation armed with four denticles, of which the second and third are the largest: legs pale chestnut ; tarsi testaceous.

In the other sex? the elytra are entire and unarmed, and the dorsai rows of punctures on the disl of the elytra are more numerous.

VARIETY B. Entirely rufous, or pale-chestnut [Quite common in Canada under bark of Pine trees.]

[192.] 256. Apate BivitTata Kirlyy.-Plate viii, fig. 5.-I.ength of body $\mathrm{I} 3 / 4$ lines. A pair taken in the Expedition.

Very near $A$. domestica ( $A$. limbata $\mathrm{F}$.) but distinct. Boty piccois or nigro-piccous, cylindrical; underneath with some scattered pale hairs. Head rough with minute elevations or granules; nose terminating in a transverse ridge; antennae testaceous vith a very large knob: prothorax subglobose, reddish, rough behind with numerous transverse rugosities ; before with sharp points or denticles; elytra with several rows of punctures, and two luteous stripes which unite at the apex of the elytrum; or perhaps it might be better to say, luteous, with two piceoiss stripes, one of the disk and the other of the side, but not reaching the apex: anus and legs testaceous.

In the other sex the front, or rather face, is hollowed out into a concavity; the prothorax is black anteriorly, and less rough from nugosities and points. [Belongs to the genus Xyloterus, Er. I,eConte (Trans. Am. Ent. Soc., 1 868) states that this species is taken from "Maine to Alaska. In the $f$ the head is concava, and the thorax finely transversely asperate before the middle; in the $q$ the head is convex, and the thorax much more roughly asperate. This species varies greatly in colour. the black elytral vittæ sometimes occupy nearly the whole surface, ane so.netimes are almost wanting."]

[193.] 257. Apate RUfitarsis Kirby.-Length of body $13 / 4$ lines. Two specimens taken in the Expedition.

Body cylindrical, black, hairy underneath. Head hairy; face concave; antennae pale testaceous : prothorax rufous posteriorly, granulated especi- 
ally anteriorly; elytra punctured in rows, rufous, with a black humeral blotch : tarsi rufous.

The face of the other sex is probably plane; and the prothorax with more prominent points and asperities. [Unknown to LeConte.]

258. Apate (Lepisomus) rufipennis Kirby.-Plate viii., fig. 2. Length of body $1 / 4$ line. Two specimens taken in Lat. $65^{\circ}$.

[!94.] Body black, minutely punctured, hairs white, decumbent ; those of the prothorax and elytra looking like minute scales. Hcad with a pair of minute tubercles, not easily discovered, in the space between the eyes, anteriorly transversely impressed; mouth and antennae pale rufous : prothorax very thickly and minutely punctured, with a rather obsolete longitudinal dorsal ridge : elytra dull-red, with several rows of larger punctures, the interstices of which are very minutely and thickly punctured, at the base rough with minute elevations : legs rufous. [Belongs to Polygraphus Fr. Taken according to LeConte in "Alaska, Canada, Maine, Louisana." (Vide Trans. A. E. Soc., Sept. 1868, p. I6g).J

259. ATATE (Lepisomus) Nigkiceps Kirby.--Length of body I line. $\Lambda$ single specimen taken in Lat. $65^{\circ}$.

Smaller than the preceding. Body rufous, minutely and thickly punctured. Head black, with a very minute tubercle between the eyes; nose impressed; antennae and underside of the head pale rufous : elytra sculptured as in the preceding species, but the rows of punctures are less conspicuous. [Synonymous with the preceding, according to LeConte.]

260. Apate (Lepisomus) BReviconnis Kirby.-Length of body . line. A single specimen taken in Lat. $65^{\circ}$.

Body black, covered with hoary hairs, above resembling scales. Antennae very short with a small knob, rufous: front without a tubercle, nose not impressed; elytra not striated. This spes seems to indicate another section of the genus. [Unknown to LeConte.]

[195.] 261. Hylurgus ruftpennis Kirby.-Length of body 3 lines. Many specimens taken in the journey from New York to Cumberlandhouse, and in Lat. $65^{\circ}$.

Body dusky, hairy, ratiher glossy, punctured. Head black, conluentiy punctured; vertex obsoletely channelled; antennac rufous: prothorax constricted anteriorly, and dusky-rufous; base with a double slight sinus, and dorsal ridge terminating in an impression at the angle between the sinuses : elytra rufous, furrowed; furrows punctured; interstices of the furrows rough with minute elevations, especially at the base, which is infiexed : tibiae and tarsi dull-rufous; the former denticulated on one side. 
N. B. In some specimens the elytra and anterior part of the prothorax are piceous or nearly black; in others tie elytra are testaceous, and the prothorax piceous and palcr anteriorly. [Belongs to Dindratonus Er. Taken in Alaska. "The punctures of the thorax are not very dense, and of two sizes intermixed."--Le Conte.]

FAMILY CUICULION!1:

[196.] 262. Calavosa protrax Olater--Length of body 7 lines. Taken in Canada by Dr. Bigsbr.

Body obversely pear-shaped, biack, naked. Head inmersed in the prothorax, smooth; rostrum rather shorter than the prothorax, compressed, impunctured, channelled above at the base and tumid; antennae a little longer than the rostrum, scape as long as the rest of the antennae, knob pear-shaped : eyes immersed, lateral, subovate, not meeting below : prothorax oblong, rather narrowest anteriorly, tricostate, the two lateral costae sending a branch towards the base; fort depressed broad punctured dull-red stripes occupy the intervals between the elevated parts; sides a little elevated and punctured; the punctures of the stripes and sides are whitish: scitellum an isosceles triangle, excavated at the base : elytra oblong, very slightly furrowed with whitish punctures in the furrows; suture, and altemate interstices, elevated; the others or depressed ones duli-red: boly underneath witi scattered whitish punctures varying in size; postpectus and tarsi chestnut. [Belongs to the genus Sfheriophorus Schonh., of the family Curculionida. Not uncommon in Canada.]

263. Hyonius conresus Kirby.-Length of body $4 \% / 4$ lines. Takeir in Canada by Dr. Ligsby, also in Massachusctts by Mr. Dral:c.

[197.] Body oblong, of a diark pitch-colour, hoary from decumbent hairs, confinently more or less punctured. Rostrum thickish and rather shorter than the prothorax; thickly and confluently. punctured: prothorax with a dorsal levigated line not leaching the base ; disk with numerous confluent irregular excarations or wrinkles ; sides confluently punctured : elytra with ten rows of oblong deep punctures, the interstices of which are confluently punctured, mottled confusedly, except at the base, with whitish hairs: thighs armed with a short tooth; tibiae, as in the other species of the genus, armed at the apex with an inflexed stout spine or claw ; tarsal claws reddish.

264. LEPYRUS colon Linn.-Length of body 6 lines. Sevcral specimens taken in Lat. $65^{\circ}$. Also taken by Dr. Bigsby in Canada.

Body black ccvered with decumbent gray hairs. Rostrum arched, thickish, a little longer than the prothorax, conilucistly punctured, having 
also a dorsal longitudinal ridge, terminating between the eyes in a little narrow excavation: prothorax narrowest anteriorly, covered with minute elevations producing wrinkles, and having also a dorsal longitudinal ridge and two oblique, rather curved stripes formed of dense white hairs : the elytra have several rows of punctures, with the interstices minutely granulated; each elytrum has a discoidal white dot a little below the middle, and, in several specimens, there is also an indistinct one between it and the apex : on each side of the abdomen unclerneath, as in $L$. arcticus, are four yellowish round spots formed of hairs. In some specimens the pubescence has a tawny hue, in others the indistinct spot is obliterated. [Taken in Canada.]

[198.] 265. LepYrus GeMelues Kirby.-Plate v., fig. 7.--L.cigth of body $7 \frac{1}{4}$ lines. A single specimen tiken in I at. $65^{\circ}$.

Body very black, covered more or less with decumbent white hairs, and also with minute tubercles. Rostrum as in L. Colun: prothorax ridged, confluently tuberculated, minutely pinctured between the tubercles, marked on each side with an oblique stripe composed of white hairs: elytra confluently tuberculated, with five pairs of longitudinal streaks, converging towards the apex : the first and fifth including the rest.

[199.] 266. Cleonis vitTatus Kirby.-Length of body $3 / 2--5$ lines. Several specimens taken in the Expedition.

Body narrow, black, covered with decumbent hoary pile. Head thickly covered with hairs, but on each side from the eye to the insertion of the antennae, the hairs are less dense, which gives the appearance of a blackish stripe; rostrum thick, shorter than the prothorax, obsolctely ridged, punctured : prothorax obsoletcly ridged, punctured with rather large scattered punctures, often concealed by the hairs, with three blackish stripes, produced as in the head by the hairs being thinner: the elytra also have three similar stripes, and are punctured in rows : the abdomen underneath appears as if dotted with black from the same cause.

\section{GENUS MACROPS.}

Body oblong, winged. Rostrum shorter than the prothorax, subcylindrical, somewhat arched, having a dorsal longitudinal ridge; bed of the scape of the antennx oblique reaching from near the apex of the nostrum to the middle of the eye; antennx apical, longer than the head, elevenjointed; scape as long as the remainder of the antennx, incrassated at the apex, reaching the eye; two next joints longer than the subsequent ones, obconical; the following four very short, top-shaped; the four last forming a subovate knob; eyes lateral, subimmersed, long, forming, in 
some measure, an isosceles triangle with the base rounded, and the vertex downwards : prothorax subglobose; antepectus emarginate, sides obsoletely lobed: scutellum very minute, triangular; coleoptera oblong : thighs unarmed; tibiæ armed with a very minute incurved spine or spur; tarsi not dilated, penultimatz joint bipartite.

At first sight the species of this little group would be set aside as belonging to Sitona Germer, with which they possess many characters in common; a closer inspection, however, will satisfactorily prove that they belong to different genera. In the genus just named, the rostrum is shorter, thicker, and channelled; the knob of the antennæ consists only of three joints, the bed of the scape turns below the eye ; the eye itself is round : the antepectus is not emarginate, or lobed; the tibix have no incurved spine.

[200.] 267. Macrors maculicolls Kirby.-Plate viii, fig. 4.Length of body 2 lines. Two specimens taken in Lat. $65^{\circ}$.

Body black, rather hoary from decumbent hairs and scales. Rostrum very minutely punctured; ridge reaching from the base to the apex; stalk of the antennx a dull-red: prothorax minutely and thickly punctured, obsoletely ridged, having the sides, especially at the base, covered with little white scales : elytra furrowed, furrows punctured : tibix, tarsi, and base of the thighs of a dull obscure red, posterior thighs on the inside more distinctiy rufous.

268. Macrops vitticollis Kirby.-Length of body $2 \frac{\pi}{4}$ lines. A single specimen taken.

Body covered with brownish-black scales. Rostrum ridged it the tip, the rest covered with scales, which perhaps conceal the remainder of the ridge; stalk of the antennæ rufous : prothorax with three narrow pale stripes, the lateral ones a iittle waved: scutellum pale; eiytra slightly furrowed; furrows minutely punctured; mottled with pale: tibiæ and tarsi, the former obscurely, rufous.

\section{[201.] GENUS LEPIDOPHORUS.}

Body covered with scales. Antennae longer than the head, elevenjointed; scape as long as the remainder of the antennae, reaching to the eye, growing gradually thicker towards the apex; pedicel as long as the two following joints, obconical ; the remaining joints of the stalk rather top-shaped; knob three-jointed, ovate, acute; rostrum shorter than the prothorax, thick, subcylindrical, straight; bed of the scape of the antennae very short, not reaching the eye ; eyes subobtusangular, with the vertex downwards: prothorax ratier longer than wide, barrel-shaped: elytra 
taken together oblong-oval: scutellum punctiform : thighs clubbed, unarmed; tibiae armed at the apex with a short incurved spine; penultimate joint of the tarsi bilobed.

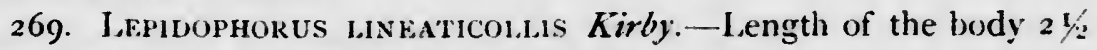
lines. Several specimens taken in Lat $65^{\circ}$.

Body black, underneath hairy with little whitish round scales and hairs of the same colour intermixed. Head and rostrum behind the antennac covered with similar scales: antennae dusky-red: prothorax dusky, confluently punctured with three whitish longitudinal narrow indistinct stripes turmed of minute scales: elytra mottled with whitish and dusky round scales; slightly furrowed with punctures in the furrows : at the apex, in the deflexed part, there is a series of white rigid minute bristles between each furrow : legs hairy, reddish brown, thighs darker.

[202.] 270. Trachyphleus Mel.anothrix Kirby:-Length of the body $23 / 4$ lines. A single specimen taken in Lat. $65^{c}$.

Body really black, but quite covered with a brown powdery substance, resembling mud or dirt. Head impressed between the eyes; rostrum longer than the head, and nearly as wide, emarginate and hairy at the end; antennae rufous, scape covered with brown powder: prothorax transverse, obsoletely channelled, with several short rigid black bristles on each side of the channel arranged nearly in rows : elytra obsoletely furrowed with slight punctures in the furrows, and between each furrow is a row of longer rigid black truncated bristles; a few white ones are discemible at the apex : legs bristly, with white bristles, rufous, but the thighs are covered with powdery scales.

[203.] 27r. Pachyrhynchus (Rhinaria) Schonherri Kirby.I ength of the body $5-7$ lines. Taken in Canada by Dr. Bigsby. Also in Georgia? by Mr. Abbott.

Body thickly covered, especially underneath, with hoary pile. Antennae shorter than the head; eyes brown: prothorax with three faint whiter stripes : scutellum white; elytra with nine rows of punctures, and at the hase of the lateral margin is a portion of a tenth row, between the second and third ; in the sixth, seventh, eighth, and ninth rows the pile is thicker than in other parts of the elytrum, so as to form three white stripes, on these stripes there are also four rows of distant black dots on each elytrum. [Not uncommon in Canada.]

[204.] 272. Attelabus similis Kirby.-Length of the body $2 y / 2$ lines. Taken in Canada by Dr. Bigsby.

This species is nearly the transcript of $A$. curculionoides, for which I at first mistook it, but a closer inspection convinced me it was distinct. 
They agree in being black, glossy, and naked ; in having a red prothorax and elytra, the latter with several. rows of punctures; in having the head and rostrum more or less punctured, with curved impressed lines on each side just above the eyes, in the disk of the front; the prothorax also in both is minutely punctured, and the cubit arched and internally serrulated. They differ, however, in several respects. In $A$. curculionoides the head is wider in proportion, the occiput black, levigated, with a central inpression; the curved lines of the front not distinctly punctured; the stalk of the antennae rufous; the prothorax at the base is streaked with transverse linear impressions; the scutellum is nearly black, and the interstices of the rows of punctures of the elytra are irregularly punctured. In $A$. similis the hinder part of the head which is punctured and wrinkled, and scutellum are rutous, a transverse impression divides the occiput from the front; the curved lines are distinctly punctured; in the front between the eyes is a wide channel; the antennae are piceous; the prothorax is not streaked at the base: and the elytra between the rows of punctures are levigated. [Synonymous with A. anulis Illig.; taken in ['anada.]

273. Atrelabus mpustuiatus Fibr.-Length of the body 2 lines. Taken in Canada, near Lake St. Clair, by Dr. Bigsby.

[205.] In sculpture this species for the most part agrees with $A$. cur(4. wnoides, except that there is an impression between the eyes, and a pair on the disk of the prothorax. The whole of the body is very black, except the shoulders of the elytra, which are covered by a large oblongr red spot, the anterior thighs are armed with a minute tooth: the disk of the coleoptera, or elytra taken together, towards the base is depressed; and the scutellum is obverseiy triangular, the vertex of the triangle pointing towards the head. ['This and the preceding species are both described and figtired in Harris' Injurious Insects, pages 65 and 66 ; taken in Canada.]

274. Aporomes ovatus Fibbr. - - length of the body $\mathrm{I} / \mathrm{t}$ line. Variety B taken by Dr. Bigsby near Lake St. Clair.

[206.] Body very short, betreen pear-shaped and ovate, deep violet, naked, minutely punctured. Head black, rostrum levigated : prothorax somewhat lozenge-shaped, emarginate anteriorly, very thickly and contuently punctured, with a levigated discoidal longitudinal line: elytrar furrowed, furrows punctured.

Variety B. Blue-green. [Belongs to Attrlalus Fabr., or Pteroulus Sch.] 
275. Axrhribus rasciatus Olizier.-length of the body 4 lines. ' laken in Canada by Dr. Bigsby.

Bedy black, covered more or less with brown decumbent short hairs. Rostrum angular, thickish, dilated at the tip, below the antennae covered thickly with snow-white decumbent pile : antennae almost as long as the thorax, rufous, knol) dusky-brown; front marked with two whitish dots, one adjoining each eye on their upper side: prothorax wrinkled with a transverse discoidal impression, and near the base with an elevated transverse ridge: elytri wrinkled with a discoidal tubercle near the base, near the apex adorned with an irregular angular band composed of snow white decumbent pile : abdomen whitish with a double indistinct series of hlack dots : titiae with a white ring.

VARIETY B. With the tubercles of the elytra less conspicuous; the abdomen snewy-white; thighs variegated with white.

I have no memorandum whence I received this variety. It is smaller, and probably American.

\section{[207.] FAMILY CI.YTHRID.E.}

276. Chlanys placata Olicier.--length of body 2 lines. Taken in Canada by Dr. Bigsby; also in Massichusetts.

Body obscure, bronzed. Head impressed posteriorly between the eyes; rhinarium, antennat, and an elevated space adjoining the eyeanteriorly, rufous; nose indistinctly punctured: prothorax very finely and concentrically scored, with some scattered indistinct punctures; posteriorly considerably elevated : elevation bifid; behind this elevation the prothorax is producted and emarginate: scutellim obtriangular: elytra tuberculated with several acute, compressed tubercles, the anterior ones carinated; interstices with some scattered deep punctures: space ietween the four posterior legs punctured with large shallow punctures-

\section{[20S.] FAMULY CRYPTOCEPHALID.F.}

277. Cryptocephalus pebrisciss Fitbr:- Length of body $21 / 4$ lines. Taken in Canada by 1)r. Bigshy.

Body black, with a zery slight brassy tint, a little glossy, grossly and thickly punctured ; downy more or less with cinerascent down : prothorax with a longitudinal levigated line, posieriorly with a double sinus : scutellum elevated towards the apex, perfectly smooth : elytra with a laterai lobe towards the base, shoulders with a tubercle. [Belongs to Suffirian's genus Pachvbrachis.]

278. Cryptocf.phalus Notarus Falr.-Iength of body $23 / 4$ lines. Taken in Canada by Dr. Bigsby. 
Body black, naked, glossy. Nose with a bilobed reddish-yellow spot at the apex; front with a yellow curvilinear spot adjoining the eyes on their inner side ; between the eyes behind is a pair of round impressions, and a longitudinal intermediate abbreviated channel; antenna mutilated in the specimen, but what remains of them is reddish yellow : prothorax levigated, but sprinkled with very minute and slight punctures, visible only under a powerful magnifier; behind with a slight sinus on each side : scutellum levigated and elevated posteriorly: elytra deeply punctured with the punctures arranged in rows, the sixth row from the suture is interrupted, and in the interstices on each side of it are some irregular punctures, the intermediate rows do not reach the apex; a luteous band, abbreviated next the suture and growing gradually wider till it reaches the lateral inargin, and an irregular spot at the apex of the same colour, distinguish the elytra.

Fabricius describes his $C$. notatus in so few words that it admits of some doubt whether his insect is synonymous with Dr. Bigsby's here characterized. The spots at the apex can scarcely be denominated puncta, but as he occasionally designates a large spot by this term, and both insects are from North America, for the present it may be allowed to stand under the above name. [Haldeman states that " $C$. notatus Fab. is southern. The northern species, described by Kirby under the same name, has been called $C$. sellatus by Suffirian." Common in Toronto and other parts of Ontario.]

[209.] 279. Eumolpus (ADoxus) vitis Fabr.-Length of body $23 / 4$ lines. Several taken in the journey from New York, in lat. $54^{\circ}$ and $65^{\circ}$.

[2ro.] Body black, a little glossy, hairy with cinerascent hairs, minutely punctured. Palpi rufous, last joint black; five first joints of the antennae rufous, the rest black : elytra and tibiae rufous.

Both Geoffroy and Fabricius complain of the ravages committed by this little species upon the vine in Europe, and probably it is equally destructive to those of America. [A very destructive insect in Furope, but of doubtful occurrence in America.]

FAAILY CHRYSOMELIDE.

280. Chrysomela Phildielphia Linn.-Iength of body $31 / 2-4-$ $43 / 4$ lines. The type and viriety $C$ taken in Canada by Dr. Bigsby. Variety B in Nova Scotia by Dr. MacCulloch.

Body oblong, black-green, naked, glossy, convex, punctured with scattered punctures. Palpi, antennae, rhinarium, and legs rufous; labrum hairy: prothorax with the punctures at the sides more numerous than 
those on the disk : elytra pallid, with a longitudinal stripe at the suture with three diverging obsolete branches, and several irregular spots; one at the shoulders larger than the rast and as it were broken, or obtusangular, all of a dark green : the elytra are grossly punctured with scattered punctures, but next the suture the punctures are disposed in two rows, the sutural one [21I] extending from the base to near the apex, where it becomes confluert with the second, both diverging towards the base and surrounding the upper branch of the sutural stripe; there is a fourth series of punctures at a little distance from the lateral margin, and the interstice between them is impunctured ; epipleura dari-green.

N.B. The two lower branches of the above stripe are surrounded by a common series of punctures.

VARiety B. Smaller, green-bronzed, green spots of the elytra more numerous, epipletra pallid.

C. Sutural stripe with only one branch, the two lower ores forming scparate splots ; epipleura pallid.

This varying species may be known from the succeding ones by the green colour of its body : all the varieties are distinguished by the obtusangular spot at the shouiders of the eiytra: the varying number of green spots on these organs is produced by tize separation of some of the irregular ones into distinct ones, and the lower branches of the sutural stripe doing the same. Variety $\mathrm{C}$ comes nearest to that figured by DeGeer and Olivier. [Quite common in Canada].

281. Chrysonela confinis Kirby.-Length of body 4 1/2 lines. single specimen taken in Nova Scotia by Capt. Hall.

Nearly related to the preceding species. Body oblong, obscurely bronzed-green, grossiy punctured. Palpi, antennae, legs, and rhinarium ferruginous: punctures of the prothorax scatiered in masses, with the interstices very minutely junctured: scutellum bronzed: elytia reddish with a discoidal flexuose irregular pale stripe dilated at the base and towards the apex; there are also two flexuose dark-green discoidal stripes in the disk, the exterior one nearly reaching the base and the interior approaching nearer to the apex, between these towards the base is a single oblong green spot, and cutside them are many irregular ones of the same colour; all these spots and stripes are convex and mostly circumscribed by punctures; there is a double series of punctures diverging towards the base; and an oblique abbreviated one between these and the scutellum, 
as in many Harpalicia, Ac. ; the interstice between the double series is green at the basc. There is a lateril scries of punctures also as in C: Philadelshica.

[Synonymous with C. Ssirncae Say. Taken on Lake Superior by Agassiz.]

[212.] 232. Chrysumela Bigseyana Kirby.-Length of body 4 lines. A single $q$ specinten taken in Canada by Dr. Bigsby. [Taken in Ontario.]

Colour and sculpture of the body like those of the preceding species, from which $C$. Bigsbyana differs principally in having the sides and the anterior margin of the prothorax reddish-yellow; the elytra are of the same colour, but the suture itself, especially at the base, a stripe parallel to it, a large humeral bilobed spot, the interior lobe of which is obtus angular or broken, and several irregular dots and spots on the elytra are black-green.

2S3. Chrisomela nultipunctata Say.-Length of body $4 \frac{1}{4} /$ lines. Taken frequently in the journey from New York to Cumberland House. [Taken in Canada.]

Body, head, antennae, and legs ferruginous. Prothorax pale-yellow, with two posterior triangular ferruginous spots with a dot of the same colour between then ; the punctures of the prothorax are more numerous and smaller than in $C$. Philadclphica, \&c.; elytra yellowish-white; suture and a confluent stripe circumscribed with the double series of punctures, diverging towards the base of the elytra, ferruginous; surface covered with irregular greenish dots and short lines, as in the preceding species, a row of punctures marks the exterior side of the elytra, the interstice between it and the margin is immaculate and impunctured, the rest of the elytrum being thickly covered with scattered minute punctures.

[213.] 284. Chrysomela chivicollis Kirby. - Length of body $4 \% 3$ lines. A single specimen taken in Canada by Dr. Bigsby.

Body between oblong and hemispherical, violet. Head punctured; labrum without punctures: prothorax elevated in the centre to an obtuse peak, from the summit of which descend several concentric channels which run nearly to the margin, the interstices of which are punctured : scutellum violet with a green tint: eiytra reddish, punctured, punctures scattered with some tendency to arrange into rows; three large dark violet spots distinguish the elytra, the first upon the shoulders subtriangular with the vertex truncated, the second near the apex bilobed, the 
third at the base forming with that on the other elytrun a large cruciform spot ; suture violet: anterior thighs armed with two stout teeth.

285. Curvowela acfipes $D_{e}$ (icir.-Length of body $23 / 4$ lines. single specimen taken in the Expedition.

[2:4.] The American differs a little from the British specimens. In the first place it is scarcely half the size, not oniy the mouth lut the space before and between the eyes is rufous, only the vertex and occiput being black: the black spot of the prothorax, instead of consisting of two distinct spots connected only at their base, is only divided at its apex into two lobes, and the spots of the elytra though similarly arranged, are less distinct: they agree in having the body underneath, except the rufous anus, black; and the legs rufous.

[Taken on Lake Superior by Agassiz's Expedition.]

286. Pufonon Adosidis P':llas. - Length of body 3-4 lines. Several specimens taken in Lat. $54^{\circ}$.

[ $\left.\begin{array}{lll}2 & 5 & 5\end{array}\right]$ Body black, punctured, sprinkled underneath with cinereous hairs. Vertex rufous with an occipital black spot: prothorax reddishyellow, with a large discoidal black spot reaching from base to apex and constricted anteriorly; on each side also there is a round black dot; scutellum black, impunctured : elytra reddish yellow, thickly punctured with scattered punctures; suture black except at the base; a black discoidal stripe or blotch reaching neither to the base nor the apex,anteriorly obliquely truncated and posteriorly acute, also distinguishes these organs.

VARIETy B. With the discoidal stripe acute at each extremity and smaller.

Variety C. With the discoidal stripe evanescent.

[Taken at Fort Simpson, Mackenzie River, by Mr. Kennicott.]

287. Phedon Raphant. Fabr.-Length of body 2\% $25-23 / 4$ lines. Several taken in Lat. $54^{\circ}$.

Body oblong, punctured, glossy; underneath black with the disk a little bronzed, above green or green-gold. Head and prothorax minutely punctured; five first joints of the antennæ bronzed and glossy; the remainder cinereous and obscure: scutellum impunctured, violet: elytra very thickly punctured, punctures not arranged in rows : parapleura confluently punctured: disk of the postpectus bronzed and transversely striated with very slightly impressed striolæ. 
In the female the abdomen, as in $P h$. Polygoni, is oftun so distended with eggs as to make the elytra appear abbreviated.

VARIETY B. With the whole of the upjer surface green, without any golden lustre.

[This and the two following species are included in the genus. Gastraphy'sa Chev.]

[216.] 288. PhaDON POLYGoni Linin-Length of body 2 lines. Taken in Nova Scotia by Dr. MacCulloch and Capt. Fiall. [Very common in Canada.]

Body oblong-ovate, punctured, glossy, underneath black. Head deep blue, with an abbreviated channel in the vertex betwcen the eyes; antenna piceous, with the first five joints rufous : prothorax corvex, rufcus : elytra deep blue, thickly punctlired: legs rufous with piceous tarsi; anus rufous.

289. Phillodecta Vitelline Linn.--Length of body 2 t/3 lines.

[217.] Body oblong, a little inclining to ovate, glossy; underneath black-bronzed, scarcely punctured; above bronzed with a copper tint, minutely punctured. First and second joints of the antennae rufous : scutellum impunctured: elytra punctured in rows, with the interstices indistinctly punctured : tarsi piceous with the first joint rufous.

[Taken on Iake Superior by Agassiz's Fxpedition; in Ontario, aiso.]

\section{Family Halticina.}

290. HalTiCa (CRChestris) vicisa Kirby--length of body $3 \frac{1}{3}$ lines. A single specimen taken.

Body underneath pale rufous with the disk of the postpectus black. Head punctured in the vertex, dirty-white, with a pair of contiguous black dots between the eyes and a subtriangular one on the nose; antennae black with the underside of the scape and the two next joints duskyrufous: prothorax very minutely and lightly punctured, white with two irregular black spots placed obliquely on each side, and a black longitudinal streak between them : scutellum black: elytra very minutely and thickly punctured, with a sutural stripe common to both, a discoidal one rather nearer the lateral margin, and another just above it all black; the intermediate stripe falls short of the apex of the elytra : the upper side of the tibiae is dusky, and the tarsi are black.

[2IS.] 291. Haltica (orchestris) puncticollis Kirby.-Plate vii, fig. 9.-Length of body $23 / 4-3$ lines. A single specimen taken in Lat. $65^{\circ}$. Taken also by Prof. Peck in New England ? 
Body subovate, very black, underneath glossy. Head irregularly punctured hehind: antennae underneath piceous at the base: protherax very minutely and lightly punctured, pale-yellow with two black round dots in the disk between which above the scutellum is a less black triangular impression: elytra very minutely and lightly punctured: forebreast pake-yellow.

VAKIl:Ty B. Filytra with a blue tint.

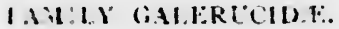

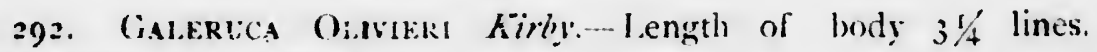
Taken in Canada by l)r. Bigsby.

Very near related to Galeruct quadrimaculati F. Body long, glossy, reddish-yellow: posterior part of the head black, a cross impressed between the eyes; antennae dusky with the four first joints rufescent : prothorax impunctured, transversely subimpressed behind, sides margined: elytra very minutely and lightly punctured with punctures just visible under a good lens ; at the base of each elytrum nearest the suture is a roundish black spot, and another large oblong one extends from above the middle towards the apex: posterior thighs a little incrassated; tarsi dusky, especially at the apex; medipectus and postpectus black.

[Synonymous with Plyyllobrotia deconata Say. Taken in "Canada, Lake Superior, Illinois ; rare. In the $f$ the $5^{\text {th }}$ ventral segment is very" Large, canaliculate, deeply excavated behind, with a small testaceous triangular appendage projecting over the oth segment. The disc of the thorax is not inupressed." f.e Conte.]

[219.] 293. Galertca Caximksis Kirly--Iength of body 4 lines. Taken in C:inada by Dr. Bigsby.

Body elongate, hairy with short decumbent cinereous hairs or down. dirty-rufous, underneath black. Head with a black vertical spot; six last joints of the antennate black, the others, except the scape, rufous black at the tip; scape rufous, black above ; prothorax transversely impressed, sides posteriorly oblicple with a slight sinus; three equidistant irregular black spots or dots placed transiersely on the disk; the two elytra taken together have three black stripes, the intermediate or sutural one being common to both, and converging with the lateral ones at the tip ; anus obscurely rufous.

[Belongs to le Conte's gents Triehabda. "A comnion species, extending from Iake Superior and the Mississippi Valley to the Facific." Le Conte.] 
294. Galertca Sacittariat Gyll.--Length of body $23 / 4$ lines. Several specimens taken in Iat. $54^{\circ}$. Taken also by Dr. Bigsby in Canada.

Body brown, a little downy, not glossy. Mouth dirty-yellow; prothorax transverse, impressed, reddish-yellow, with three black nearly confluent spots ; scutellum subquadrangular, truncated at the apex; elytra grossly but not thickly punctured; suture and lateral margin paler than the rest of the elytrum : anus and legs reddish-yellow ; tarsi darker.

VARIETY B. With the base of the antenna yellowish underneath, the black spots on the prothorax distinct, and the elytra entirely of a brownish yellow.

I"Found throughout the middle and northern parts of the Atlantic district." Le Conte.]

[220.] 295. Galferlca bulineata Kirly.-I ength of body 2 lines. A single specimen taken in Lat. $54^{\circ}$.

Nearly related to the preceding species, but smaller, the whole of the head is rufous, the joints of the antennæ are shorter; the prothorax is longer in proportion to its width; and the elytra, nearer the suture than the lateral margin, have two somewhat elevated approximated blackish ridges, the interior one being the shortest and extending from near the middle to the base, and the other reaching neither base nor apex.

[Considered by I.e Conte as probably a specimen of $G$. notulatia Fab., with indistinct markings.]

296. Cialerlca margixelia Kirby-Length of body 3 lines. A single specimen taken in I at. $65^{\circ}$.

Body very black, a little downy. Mouth and base of the first joint of the antennae subtestaceous or reddish-yellow; prothorax wider than long, impressed and confluently punctured on each side, with a longitudinal dorsal channel; behind the margin has a slight sinus; reddish-yellow with three black spots, the intermediate one being the smillest; elytra grossly and thickly punctured; lateral margin and apex reddish-yellow; legs dusky yellow: last ventral segment of the abdomen yellow and deeply enarginate.

JLe Conte refers a specinen from Fort Simpson, Hudson's Bay Territory, to this species.]

\section{[221.] FAMII.Y SACIKIU.玉.}

297. Orsodacia Timalis Nirby.-Length of body $23 / 4$ lines. A single specimen taken in the journey from New York to Cumberlandhouse. 
Body piceous ; underneath hoary with decumbent hairs ; above naked, glossy, thickly puncturer. Palpi and two last joints of the antennae obscurely rufous ; front between the eyes with a transwerse levigated elevation; prothorax longer than wide, constricted at the base; lateral margin and epipleurae or side-covers of the elytra, except at the base, yellowish-red; thighs, at the base, and tibiae reddish-yellow, the four posterior tibiae darker at the apex.

[Taken at Lake Superior by Agassiz's Expedition.]

298. Orsodacxi Chmsersi Kirly.--Plate vii, fig. 6. Length of body $23 / 4$ lines. A single specimen taken in Lat. $54^{\circ}$.

[222.] Body above punctured, naked. Head and its organs yellow, with the eyes, occiput, and apex of the mandibles black; a levigated transverse elevation of the front, as in the preceding species; prothorax longer than wide, constricted at the base, with an impression in the middle, pale-yellow, disk embrowned; scutellum rufous; elytra rather paler than the prothorax, with a stripe adjoining the lateral margin, an angular band beyond the middle and the base, black; antepectus, anus, and legs, yellow, rest of the underside of the body is black, and hoary with decumbent white hairs.

[Taken in Canada.]

FAIILF DONACIAD.E.

299. Hemonia vignicoris Kirby.-Length of body $3 \frac{2}{3}$ lines. Taken in Canada by Dr. Bigsby.

This species is considerably larger than $H$. Equiseti and Zosterie, from which it is perfectly distinct. Body luteous above and glossy; underneath it is covered with a thick coat of pale, decumbent, rather silky hairs, with somewhat of a golden splendor, if these are rubbed off, the colour of the breast and basal abdominal segment is black. Head hairy, dusky, with a levigated naked testaceous longitudinal elevation between the eyes; antennae black, robust, very little longer than the prothorax; prothorax subquadrangular with prominent anterior and posterior angles making it appear constricted in the niddle, it is channelled with an irregular discoidal impression on each side; a few large dusky punctures are observable where the channel terminates; elytra with ten equidistant rows of large punctures which converge at the apex ; besides these there is an abbreviated row at the base next the suture, as in many Harpalida, \&c., the apex 
of the elytra terminates in two teeth or spines; the inner one short and dentiform, the outer one long and spiniform ; legs and anal portion of the abdomen yellow, the former with all their articulations dusky at the extremity.

The sculpiture of the elytra in this species much resembles that of another aljuatic genus /haliplus, lat.

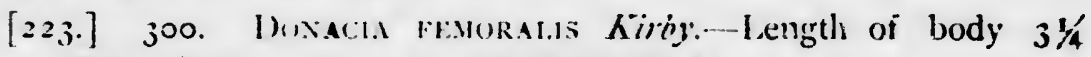
lines. Taken in Nova Scotia by Dr. MacCulloch.

Body bronzed, gilded, with a greenish tint, rery minutely and thickly punctured, not conspicuously hairy underneath. Frontal channel slight; antennae, except the scape which is bronzed, and mouth rufous; prothorax with an impression above the scutellum: anterior tubercles more than usually prominent; scutellum rather large; elytra with single slight anterior impression adjoining the suture; legs rufous, but the thighs, which are much incrassated, except the base and summit, are greenbronzed; posterior thigh without any tooth; abdomen as in the preceding species.

This species seems nearly related to Donacia pusilla Say.

3ว. Doxach rintes Kirly. - Length of hody 4 lines. A single specimen taken in Lat. $65^{\circ}$.

Body bronzed-copper with a golden lustre; clothed below with very hort, somewhat silvery, decumbent hairs, the metallic splendor of the body being visible through them. Head thickly, minutely, and confluently punctured or wrinkled, channelled between the eyes; antennac testaceous, longer than the prothorax ; prothorax subquadrangular, longer than usual in the genus, widely channelled, very minutely, thickly, and confluently punctured and wrinkled; anterior tubercles large and not prominent; elytra with two impressions adjoining the suture, clevatcd at the base ; legs testaceous.

[Taken in Ontario and at lake superior].

302. Doxacia afrists Kirby.--l.ength of body $3 \% \frac{34}{4}$ lines. Taken by Dr. MacCulloch in Nova Scotia.

Body minutely punctured, copper-coloured brilliant with the splendor of gold; underneath very sliglit!y hairy, Head channelled between the eyes; antennae and mouth testaceous ; prothorax widest anteriorly, channelled, punctured but not thickly, lateral anterior tubercles levigated; scutellum small ; elytra with a single impression, not far from the base, 
adjoining the suture; base elevated; margin of the ventral segments of the abdumen of a tine bright, the anus of a deeper orange; legs testaceous.

Very near D. flripes, but the sculpture of the prothorax, the impressions of the elytra, and the colour of the underside of the abdomen are different. It differs from $D$. discolor in having the prothorax much more thinly punctured, the anterior tubercles, which in that species are near obsolete, more prominent, and the scutellum much smaller.

[Named $D$. Kirb] $i$ by Lacordaire.]

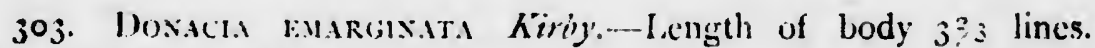
Taken with the preceding.

[225.] Body black-blue, clothed underneath with pile, in certain lights, glittering like silver. Intennac black; tubercles of the prothorax prominent ; elytra with an impression near the suture; last dorsal segment of the abdomen emarginate; thighs very thick, bronzed, posterior one with a stout tooth.

This species comes very near $D$. serical, but it is sufficiently distinguished by its deeply notched podex, and the silver pile that clothes its body underneath, which in that species has a golden lustre.

[Taken in Canada and at lake Superior.]

304. Dovicia proxina Kirby.--Length of body 5 lines. Taken in Canada by Dr. Bigsby.

Body a little flattened, covered underneath with a dense coat of glittering silver pile resembling satin. Head a little bronzed, channelled between the eyes, minutely punctured; palpi testaceous; antennae entirely black; prothorax in the disk dark violet and channelled, sides bronzed and impressed; anterior tubercles not prominent; scutellum bronzed; elytra nearly black with a slight tint of violet, punctures green-gilt, interstices of the rows not wrinkled; an anterior impression near the suture; rounded at the apex; posterior legs long, with thighs somewhat curved, attenuated at the base, armed at the apex with two teeth placed consecutively, the nirst long, slender, and acute; the last wide, short. and denticulated posteriorly.

This species is nearly related to $D$. crassipes Fab., but the antennac and the legs are entirely black, the teeth on the posterior thighs are not equal. 
[Probably synonymous with $D$. episcupalis Lac. Taken on shore of Lake Superior.]

305. DonaCla cuprea Kirby.--Length of body 4 将 lines. Taken in Canada by Dr. Bigsby [also on Lake Superior.]

[226.] Body above copper-coloured, glossy; underneath covered with a thick coat of decumbent pile of a cinereous colour, glittering in certain lights. Head downy, channelled; month and palpi rufous; mandibles and antennae black; prothorax rather wider than long, very minutely, thickly and confluently punctured and wrinkled; channelled, with a pair of impressions on each side, anterior tubercles not prominent ; scutellum downy : elytra very grossly punctured in rows; a single anterior impression near the suture; truncated at the apex; three intermediate ventral segments of the abdomen have a yellow margin ; legs obscurely rufous; thighs bronzed in the middle; posterior thiglis with a minute tooth near the apex.

306. DONACTA niRTicos.s. Kirby.-Length of body 3 , lines. A single specimen taken in Lat. $65^{\circ}$.

Body underneath covered with a thick coat of decumbent pile resembling satin and shining like siiver. Head hoary from inconspicuous hairs, most minutely and confluently punctured with a slight interocular channel with an obtuse ridge on each side; antennac with the second and third joints equal in length ; labrum glittering with silver pile; prothorax longer than wide, hoary from inconspicuous down, most minutely and confluently punciured, channelled, sides subimpressed, anterior tubercles flat ; scutellum large, levigated ; elytra black, punctured in rows, whose interstices are wrinkled; posterior thighs with a single short obtusangular tooth.

This pretty species comes near $D$. bidens Oliv., which 1 always find on Potamogeton natans, but it is sufficiently distinguished by its black thorax hoary from down, and legs without any red.

[Synonymous with D. rudicollis Lac. Taken on Lake Superior.]

307. Donacia EqLal.ts Say.-Length of body 4-4 $\frac{1}{2}$ lines. Many taken in the journey from New York to Cumberland-house [also in On. tario.]

[227.] Body underneath covered with a thick coat of silver pile as in the preceding species. Head bronzed, hoary from cinereous down, minutely and confluently punctured, channelled between the eyes with a. 
longitudinal obtuse ridge on each side the channel; antennae black, bronzed at the base, second and third joints equal in length; mouth piceous; prothorax bronzed and gilded, rather longer than wide, thickly and conflnently punctured and wrinkled; channelled; sides longitudinally subimpressed; anterior tubercles obsolete ; scutellum hoary from down ; elytra bronzed, gilded, punctured in rows except at the apex where the punctures are confluent, two impressions adjoining the suture, and one in the middle of the base; apex truncated; ventral segments of the abdomen. the last excepted, with a bright orange margin; posterior thighs with a stout short tooth.

N. B. In the male the ventral segments are without the orange margin.

VARIETY B. Prothorax bright copper, elytra black-bronzed.

FAMII.Y HISPID.E.

308. Hisp. (Anoplitis) BICO1.or Oliv.-Length of body $33 / 4$ lines Taken in Canada by Dr. Bigsby. Mr. Francillon had specimens from Georgia. Oliv.

[2 28.] Body linear, naked. Head black, smooth,channelled between the eyes; antennae robust, scarcely longer than the prothorax, black; eyes large, dark-brown; prothorax transverse, narrowest anteriorly, red, with four dusky spots placed transversely, grossly punctured, posterior angles producted, behind with a slight sinus on each side; space above the scutellum truncate; scutellum dull-red; elytra linear, black, threc-ridged, with an abbreviated ridge towards the apex between the second and third ; ridges elevated ; interstices with a double series of large and very close punctures: between the second and third at the base and apex the series is quadruple, in the middle triple; lateral margin and apex serrulate; underside of the body blood-red; legs black, base of the thighs red.

HAMILY COCCINELILID.F.

309. Coccinfili.A F.PIscopal.is Kirby.--Plate v, fig. 4. l.ength of body 2 lines. Taken in the journey from New York to Cumberland. house.

[229.] Body narrow, nearly linear, having at first sight the aspect of a Haltica, underneath black. Head black with three oblong pale yellow spots, two adjoining the eyes on their inner side, and one placed backwards in the vertex; mouth, antennae, and palpi rufous; prothorax and 
both elytra taken together, pale yellow with two black stripes, common to both, resembling a bishop's crosier, the crook being on the thorax and the stalk on the elytra; suture of the latter black except at the tip; legs pale testaceous; anus, sides of the abdomen, and tijss of the ventral segment, except the basal one, pale.

[Belongs to Nirmia MLuls.]

310. CoccixfitiA TREDEcin-plxctata Linn.-l.ength of body 3 lines. Several specimens taken in Lat. $54^{\circ}$.

looly oblong, black, lightly and minutely punctured; underneath slightly downy. Mouth and its organs pale rufous ; nose white, whiteness with a posterior central lobe; antennae rufous; prothorax white with a large discoidal spot falling short of the anterior margin, where it is truncated; sides lobed, besides which there is a black dot on each side connected with the above spot; elytra reddish-yellow with six largish black dots, namely 1, 2, 2, 1, and one at the scutellum common to both elytra ; the first marginal dot is ovate, the rest approaching to round ; the tibiae and tarsi are testaceous; there are two transverse white spots on each side the breast, between the four posterior legs; and four triangular pale ones on each side the abdomen.

VARIETY B. Nose rufous, with a parallegramniscal white spot between the antennae.

[Belongs to Hippodamiir Muls. ; very common in Canada.]

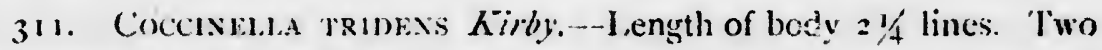
specimens taken in the Expedition.

[230.] Body rather oblong, very minutely punctured; black underneath, with two distant white spots on the breast, and three contiguous ones on each side of the abdomen. Head black with a transverse white band or trident between the eyes, tricuspidate both anteriorly and posteriorly; the intermediate posterior lobe the longest; prothorax white with a large bipartite black spot, each lobe being trilobed with rounded lobes resembling a trefoil leaf and connected with the other by a transverse band; elytra pale reldish-yellow; with three black spots and one at the scutellum common to both elytra, placed 2, 1, 1; the scutellar spot somewhat bell-shaped, the humeral one roundish, the intermediate one nearly kidney-shaped, and that nearest the apex rather crescent-shaped.

VARIETY B. Frontal band replaced by three white spots, the intermediate the longest and linear. 
This species seems to come near $C$. Parenthesis Say, but still may be distinct.

[Considered to be a variety of Hippolimia parenthesis Say, a species not uncommon in Canada.]

3r 2. Coccinella Quinque-signata Kirby.-Plate vii, fig. I. Length of body 3 lines. A single specimen taken in Lat. $65^{\circ}$.

Body oblong-hemispherical, very minutely and thickly punctured; underneath black and a little downy. Head black with an acute white spot in the forehead between the eyes; antennae obscurely rufous, dusky at the base and tip; prothorax black, anterior angles and intermediate streak white; elytra tawny yellow with an abbreviated band common to both at the base, an oblique discoidal abbreviated band and apical dot, black ; four distant lateral triangular white spots mark the breast.

313. Coccinfila Quinoue-notata Käby. - Length of body $33^{1 / 3}$ lines. A single specimen taken in Lat. $54^{\circ}$. Taken also by Dr. Bigsby in Canada.

]23r.] Very like the last, but shorter and more hemispherical. Two subtriangular transverse spots between the eyes, apex of the nose, dot at the sinus of the eyes, and anterior angles of the prothorax whitish-yellow ; basal band of the elytra broadest at the suture, the two other black spots are of equal size and placed transversely, and each forms an abbreviated band, falling far stort of the suture and the lateral margin, so as to be scarcely more than two transverse spots; scutellar angle of the elytra paler than the rest : the breast has no white spots. In other respects it is exactly like $C$. 5-signata.

314. Coccinella tricuspis Kirby.-length of body $21 / 4$ lines. Several specimens taken in the Journey from New York to Cumberlandhouse.

Body black, punctured. Head with two irregular transverse yellow spots between the eyes; antennae pale rufous, black at the tip : prothorax with the anterior angles and a slender portion of the anterior margin yellow, the black part forming a large three-lobed spot; the middle lobe being the longest and truncated, the lateral ones shorter and rounded; elytra tawny-rufous, paler and almost yellow at the base and sides, where there is a black band common to both elytra not reaching the lateral margin, which anteriorly has a double sinus so as to form three triangular lobes or points in the band; towards the apex of each elytrum is another: irregular black band, which reaches neither the suture nor the margin. 
315. Coccineli a incarnata Kirby.-Plate vii, fig. 7. I.ength of body 2 lines. A single specimen taken in I.at. $65^{\circ}$.

[232.] Hody black. Mouth and its organs and antennae reddish; prothorax flesh-coloured with two large subquadrangular black spots, separated by a narrcw flesh-coloured stripe, which occupy almost all the disk: elytra flesh-coloured, taken together with eleven roundish rather large black spots, three of which are common to both elytra, viz. 3, 4, 3, $\mathrm{I}$, the common spot at the apex is transverse ; legs black with the base of the thighs and tibiae, tarsi, sides of the abdomen, and anus testaceous.

This species seens to come near $C$. lorealis of 'Thunberg, but it differs in colour and the number and disposition of the spots.

FAMILY PIMELIAD.\$.

316. Pimelia alternata Kirby.-Plate v, fig. 9. Length of body $61 / 2$ lines. A single specimen taken at Carlton-house, Lat. $53^{\circ}$, in April.

[233.] Body dull-black, oblong, naked. Head minutely punctured; antennae shorter than the prothorax; prothorax widest in the middle, subquadrangular with the sides rounded, minutely but not very thickly punctured, with some slight impressions in the disk: scutellum short, wide, rounded at the apex; elytra with six elevated granulated lines alternately more pronounced, besides the suture and marginal one separating the epipleura, which meet just above the apex ; epipleura granulated : posterior legs much longer than the four anterior.

Mr. Say says of his $P$. roturda that it was the first of that genus found on the New Continent; that above described furnishes therefore a valuable addition to the American insect Fauna. Africa appears to be the metropolis of the genus, though several species have been found in Russian Tartary.

[A species of Eleodes, synonymous with Say's Eleodes (Blaps) tricostata.

\section{FAMILY TENEBRIONIDE.}

317. UPIS Ceramboides Linn.-Length of body $8-81 / 2$ lines. A pair taken in the month of April, in Lat. $65^{\circ}$. Taken also in Canada by Dr. Bigsby. [Abundant throughout Canada; taken by Agassiz's Expedition on Iake Superior.]

Body dull-black, narrow, naked, minutely punctured. Head nearly round depressed, porrected; eyes lateral, kidney-shaped; nose circum- 
scribed by the segment of a circle; antennae a little shorter than the prothorax, joints obconical, four last lentile-shaped; prothorax a little wider than the head, oblong with rounded sides; scutellum rouncled at the apex ; elytra taken together wider than the prothorax, a little dilated beyond the middle, and then sloping to the apex, which is acute; very unequal with numerous irregular deep impressions and rugosities, variously separated by a number of elevated lines or obtuse ridges running confusedly in various directions; legs long; thighs incrassated; tibiae and tarsi slender.

[234.] 318. Trinebrio Molitor Linn.-Length of body $7 \frac{1}{2}$ lines. Taken in Nova Scotia by Capt. Ha!l.

Body oblong-linear, minutely and numerously punctured, a little glossy, naked, above piceous, underneath rufo-piceous. Head uneven, nearly orbicular ; anteriorly rufo-piceous ; antennae and palpi rufo-piceous; prothorax transverse, sides rounded with a reflexed margin; posterior margin wavy, just above which, on each side, is a roundish impression; posterior angles acuminate: scutellum transverse, subacuminate : elytra scarcely wider than the prothorax, slightly furrowed, furrows punctured with the interstices transversely somewhat wrinkled, and most numerously and minutely punctured; shoulders short, compressed and incrassated; cubit curved.

LAn introduced European species that has spread all over Canada and the Northern States, and has become a great pest to millers, flour dealers and house-keepers.]

Tenebrio Pennsylvanicus Knoch.-Length of body 8-9 lines. Several specimens taken in Lat. $54^{\circ}$; it was also sent me by Dr. Harris.

[235.] Body long, rather widest towards the anus, black, minutely punctured, naked, not glossy. Head somewhat quadrangular, longer than in the preceding species, uneven; prothorax nearly square with a minute impression above the scutellum; posterior margin wavy; lateral very slender and a litlle rounded; scutellum subtriangular; elytra with nine rows, including the marginal one, of punctures, and an abbreviated one at the base next the suture; under a powerful lens the interstices are minutely but not thickly punctured: the shoulders are scarcely thicker than the thighs.

[Belongs to Nyctobates Guen. ; very abundant throughout Canada]. 
FAMILY DIAPERIDE.

320. Diaperis (.4rhenoplita) BICORnis.-Oliz.--Length of body male $1 \frac{1}{2}$, female 2 lines. Several taken in the route from New York to Cumberland-house.

Body punctured, glossy ; underneath black, above black-bronzed or green-bronzed. Head of the female transversely impressed between the eyes, unarmed; in the male just behind the eyes is a pair of long cylindrical vertical piceous horns rather paler at the apex, between which is a deep excavation; the nose also at the apex is armed with a pair of minute triangular teeth; mouth, in both sexes, rufous: antennae black with the three first joints attenuated and rufous: prothorax transverse with the sides rounded, posteriorly obtusangular but not lobed; scutellum triangular ; eiytra slightly furrowed with the furrows punctured; interstices minutely punctured; anus underneath with two transverse obtuse ridges ; legs rufous.

[Belongs to Hoplocephala Lap. ; quite common in Canada.]

\section{[236.] FAMILY BOLITOPHAGIDE.}

321. Bolitophagus curnutus Fabr.-I ength of body 5 lines. Taken in Canada by Dr. Bigsby, in a Boletus of the birch, near Lake Huron. [Quite common in old dry fungi on trees and stumps. For description and figures see Say's Amer. Entomology, vol. i, p. I r4, plate 51. With regard to the orthography of this word, we may mention that the Greek term is Bolites, and the Latin Boletus; as the termination phagus is Greek the generic name of the insect should be written as above, Bolitophagus, while Boletus is quite correct as applied to the fungus.]

322. Boltrophagus OBCordatus Kirby.-Length of body $6 \% / 4$ lines. Taken in Nova Scotia by Capt. Hall.

Body linear-oblong, pollinose... Head brown-black; subtriangular; labrum ciliated with yellow hairs; antennae black-piceous, last joint smaller than the two antecedent ones, which are bigger than the rest : prothorax brown-black, obcordate with a larger anterior sinus for the head ; surface flat, uneven behind from five obtuse ridges, the lateral ones abbreviated, and before from several rounded tubercles : scutellum minute : 
elytra embrowned with a yellowish tint from lutose scales, anteriorly [237] with three obtuse ridges : thie interior one very short; the intermediate one discoidal, abbreviated at each end; and the exterior one reaching from the base to the apical tubercles, of which there are two much elevated, the interior one being the largest and highest ; in the interstices there are four rows of deep impressions: the sides of the antepectus are verrucose; the abdomen is black-brown with lutose sides; the disk is longitudinally, densely, and thickly wrinkle'. nnd the sides are verrucose; legs black-brow'n.

'This species differs from the preceding one in the form of the thorax and the clava of the antennae, and ought perhaps to fc:m a subgenus.

[Belongs to Nosoderma Esch. : rather rare in Canada.]

FAMILY HELOPIDE.

Genus Meracantha Kirby.-Iabrum transverse, scarcely emarginate ; labium subtriangular, longitudinally and obtusely ridged in the middle with a deep impression on each side; mandibles bidentate? at the apex ; maxillæ mutilated ; maxillary palpi first joint minute : second longer than the rest, clavate ; third obconical ; fourth very large, securiform ; labial palpi broken off; mentum trapazoidal; antennae filiform, scape incrassated; pedicel ouconical ; third joint longer than the rest, subcylindrical, a little incrassated at the apex ; fourth shorter than the fifth, subobconicai ; fifth longer than the subsequent ones, elongate, obconical; 6-10 obconical, gradually decreasing in length, and the $9^{\text {th }}$ and 1 oth in thickness ; I I th ovate acute.

Body ovate, convex, apterous. Head triangular; front elevated on each side at the eyes protecting the base of the antennae; eyes large, lateral, internally emarginate. Prothorax rather wider than long, narrowest anteriorly, subquadrangular; margined on the sides and anteriorly, margin very slencer. Scutellum an obtusangled triangle. Flytra with the epipleura narrow, falciform; shoulders incrassated, armed with a tooth; calcaria very short and scarcely visible.

[238.] 323. Meracantha Canadensis Kirby. -Length of body 6 lines. Taken in Canada by Dr. Bigsby.

Body black-bronzed, naked, glossy, punctured : on the upper side of the body the colour is more metallic. Head and prothorax confluently punctured, two last joints of the antennae pale from hairs ; elytra slightly furrowed, the sutural and the marginal furrows meeting at the apex and 
including the rest; furrows punctured; interstices very minutely and thinly punctured; sides of the abdomen longitudinally wrinkled : tooth of the shoulder short and wide, placed a little above the middle.

\section{FAMILY STENOCHIADE.}

Genus Arthromacra Kirby.--Labrum transverse; labium dilated above the insertion of the palpi, subemarginate: mandibles bidentate at the apex; maxillæ bilobed; lobes thick, obtuse; maxillary palpi incurved, four-jointed; first joint minute ; second longer than the rest, clavate; third shorter than the fourth, triangular; fourth very large securiform, with the truncature oblique : labial palpi three-jointed, last joint securiform ; mentum obtriangular ; antennae filiform, eleven-jointed ; scape short, incrassated; pedicel short, incrassated at the apex ; joints $3-8$ obconical, nearly twice the length of the pedicel ; last joint cylindrical, downy, as long as the five antecedent ones taken together.

Body long and slender; head triangular; eyes kidney-shaped; prothorax cylindrical, not wider than the head; scutellum rounded; elytra wider than the thorax, linear; legs slender; tarsi very long.

[239.] 324. Arthromacra DonacioIDES Kirby.-Iength of body 5 lines. Taken in Canada, near Iake St. Clair, by Dr. Bigsby. Specimens also from Massachusetts.

Body black-bronzed with a greenish tint, glossy, with the whole upper surface thickly aud irregularly punctured ; underneath, except the sides of the trunk, impunctured. Antennae much longer than the head and prothorax, scape and pedicel dusky, $3-8$ joints tawny-yellow : last joint black, downy ; prothorax nearly cylindrical ; elytra wider than the prothorax, obtuse at the apex ; thighs a little incrassated; apex of the cubit and tarsi tawny-yellow; two last joints of the latter dusky.

This singular insect, at first sight, looks very like a Donacia, a resemblance merely given by its colour.

[Belongs to Statyra Latr.; previously described as Lagria acnea by Say (Am. Ent. i, 191) ; not uncommon in Canada.]

FAMILY CISTELIDE.

325. Cistela erythropa Kirby.-Length of body 5 lines. Taken in Canada by Dr. Bigsby. 
Body elliptical, gloss obscured, especially on the elytra, by very short decumbent hairs. Head longitudinally and slightly impressed between the eyes; antennae longer than the prothorax, reddish brown, with the three first joints rufous: prothorax transverse, anteriorly not wider than the head, posteriorly obsoletely trilobed, and nearly as wide as the elytra ; lateral angles acute ; elytra slightly furrowed ; furrows scarcely punctured; legs pale rufous ; posterior tarsi long, embrowned.

\section{[240.] FAMILY DIRCEIDA.}

326. Xritita buprestoides Payk.-Length of body 3 lines. 'Taken in Canada by Dr. Bigsby.

Body narrow, black-brown, very minutely and thickly punctured, sprinkled with short decumbent pale hairs, not glossy. Head inserted ; eyes hemispherical; palpi rufous; antennae nearly as long as the prothorax, ferruginous, a little embrowned at the apex; prothorax not wider than long, anteriorly narrowest, posteriorly obsoletely trilobed; sides rounded; scutellum transverse; elytra very little wider than the prothorax ; tarsi ferruginous.

[Taken by Agassiz's Expedition to Lake Superior.]

\section{F.MILY ANTHICID.E.}

327. Notoxus monodon Fabr.-Length of body $12 / 3$ line. A single specimen taken in Lat. $65^{\circ}$.

[24r.] Body hairy with pale hairs. Head blackish; mouth, palpi, and antennae testaceous; prothorax testaceous; horn convex above, margin denticulated; elytra testaceous with a blackish band ncar the apex which rises upwards at the suture, and three blackish spots ; two at the base, and one between the band and the apex, the last very faint ; legs testaceous ; postpectus and base of the abdomen embrowned; the remainder of the prone part of the body is testaceous.

[Not uncommon in Canada. Described and figured by Say (Am. Ent., i, 2 I, plate 10). $]$

\section{FAMILY CANTHARIDE.}

328. Cantharis unicolor Kirby.--Length of body 7 lines. Taken in Canada by Dr. Bigsby. 
Body black, hoary from numerous decumbent white hairs; antennae subsetaceous, a little longer than the prothorax; two first joints very long, the first curved and nearly twice the length of the second; and the second as long as the three following ones together; prothorax rather bell-shaped, channelled; wings embrowned.

[Belongs to the genus Epicauti Red.]

[242.] 329. MELOE IMPRESSA Kirby.-Iength of body $5 \% / 4$ lines. A single specimen taken in Lat. $65^{\circ}$.

Nearly related to Meloe violacea, but very much smaller. Body violetcoloured. Head with scattered but not large punctures; front between the antennae transversely and obtusely elevated; antennae irregular; prothorax not much narrower than the head, anteriorly rounded, posteriorly narrower and emarginate, towards the base with a deepish impression, with several scattered but not large punctures, and two little transverse oblique crescents formed of punctures ; elytra wrinkled ; outer claws ar.d spurs rufo-piceous, inner claws paler.

330. Meloe nigra Kirby.-Length of body 6 lines. A single specimen taken in Lat. $65^{\circ}$.

Extremely similar to the preceding species, but the body is all black with no tint of violet, except the base of the antennae below the band and the tibiae and tarsi; the head and prothorax are more thickly punctured, and the claws and spurs are ferruginous.

[Previously described as $M$. conferta, Say.]

\section{[243.] FAMIIY MELYRID.E.}

331. DastTes fovelcollis Kirby.-Length of body $23 / 4$ lines A single specimen taken in the Journey from New York to Cumberlandhouse.

Body somewhat hairy, underneath black and glossy; above with a blue tint. Head glossy, punctured with largish scattered punctures ; front with two impressions : prothorax nearly square, with the sides a little curved, punctured at the head, with a pair of transverse anterior impressions ; sides and base margined, margin reflexed; elytra less glossy than the rest of the body, minutely, but not conspicuously, punctured.

[Belongs to the family Malachiida.] 


\section{FAMILY CLERIDA}

332. Necromia violacea Linn.-Length of body $2 / 3$ lines. Taken abundantly on the journey.

[244.] Body dark blue, glossy, minutely punctured, rather hairy. Punctures on the head and prothorax nearly confluent and larger than those of the underside of the body; antennae black, last joint subquadrangular; sides of the prothorax obtusangular; scutellum black; longer punctures of the anterior half of the elytra arranged in rows, with the interstices minutely punctured; the rows then disappear, and the whole of the apex is indiscriminately and minutely punctured ; legs black with a tint of brown.

\section{['Taken in Canada.]}

333. Thanasimus abdominalis Kirby.-Plate ii, fig. 5.-Length of body $4 / 2$ lines. Several specimens taken in Lat. $65^{\circ}$.

Body black, hairy, with longish white and some black hairs. Head punctured with two posterioriy converging inpressed lines between the eyes ; palpi and antennae dull rufous, last joint of the labial palpi, which are more than twice the length of the maxillary, very large and semicordate; last joint of the antennae, which are shorter than the prothorax, ovate and subacuminate ; eyes kidney [245] -shaped, rufous, with a golden lustre; prothorax thickly punctured, not wider and not much longer than the head, constricted behind, and anteriorly with a pair of oblique impressions, one on each side; clytra minutely punctured, with larger punctures arranged in five rows, the two exterior ones reaching from the shoulder to the midd:e, and the interior ones not so far ; the elytra are traversed by a pair of white undulato-angular bands formed of decumbent hairs; the first begins at the base below the scutellum, and running down along the suture for a little way, then diverges and forms the band, which is uroadest at the lateral margin; the other band is near the apex, broad, and projects anteriorly into an angle; the legs are dull rufous; the abdomen is between testaceous and orange, with the tips of the segments paler.

[Synonymous with T: (Clerus) undulatus Say. Kirby's name abdominalis being preoccupied, was changed by Klug to mubilus, who did not recognize the identity with Say's species. Is occasionally taken in Canada.]

\section{FAMILY CYPHONIDA.}

334. Cyphon fusciceps Kirby.-Length of body $13 / 4$ lines. A single specimen taken. 
Body lurid, downy. Head brown, mouth lurid; antennae mutilated in the specimen, but what remains is brown ; prothorax very short, transverse, slightly bisinuate both anteriorly and posteriorly; disk embrowned; elytra very minutely and thickly punctured; breast and belly brown; thighs embrowned.

[Is taken in Canada.]

HAMIIY TELAPHOKIDE.

335. Telephorus atik l.inn.-I, - Iength of body $23 / 4$ lines. A single specimen taken in the journey from New York to Cumberland-house.

[246.] Body black, rather hairy. Head suborbicular, obsoletely channelled; mouth, palpi, and base of the antennat, rufous; prothorax rather wider than long, very glossy ; disk obsoletely channelled and a little elevated on each side the channel; anterior angles rounded; elytra minutely and confluently punctured, when elevated from the body they appear embrowned; tip of the thighs, tibiae, and tarsi, rufous.

336. 'Telephorus Westwuod! Kirly. - I ength of body $5 \frac{1}{4}$ lines. A single specimen taken in lat. $65^{\circ}$.

Body black, downy. Head suborbicular, rufous with a black anteriorly tridentate band between the eyes; mandibles and palpi dusky at the tip; antennae shorter than the lody, with the scape and the base of the pedicel or second joint, rufous ; prothorax rufous, rather wider than long, anteriorly rounded, posteriorly transverse with the margin much reflexed; disk slightly channelled; elytra obsoletely punctured, or wrinkled, with three obsolete longitudinal elevated lines, the outer one abbreviated at both ends; legs dusky, base and apex of the four anterior thighs rufous; posterior thighs rufous, dusky at the tip.

337. Telephorus Samuvelli Kirby.--Length of body $5 \frac{1}{4}$ lines. Taken in the route from New York, in Lat. $65^{\circ}$, and in the Rocky Mountains.

Very like $T$. Westrioodii, l)ut the antennae are dusky, pale at the base; between the eyes is a faint dusky cloud; the scutellum and the legs are testaceous, as are the sides and tips of the ventral segments of the abdomen as well as the anus.

[247] 338. Telephorus Curtisil Kirby.-Length of body $4 \frac{1}{4}$ lines. Taken in Lat. $65^{\circ}$.

Very like the preceding species, but it is smaller; there is a black band between the eyes; the prothorax is considerably longer and 
narrower in proportion, the posterior angles are more acute, and the tarsi are black.

[Taken by Agassiz's Expedition to Lake Superior.]

339. Telephorus (Malthacus) Puncticolis Kirby.--Plate vii, fig. 4. - Length of body $2 \mathrm{I} / 3$ lines. A single specimen taken in Lat. $54^{\circ}$.

[248]. Body black, rather hairy, with short decumbent white hairs. Head rhomboidal, lightly and minutely punctured; posteriorly obsoletely channelled ; impressed between the eyes ; pale-yellow beiow the antennæ ; antennae longer than the prothorax, three first joints underneath of a dull-red, second and third, taken together, scarcely longer than the fourth ; prothorax nearly square, lightly and very minutely punctured; anterior angles rounded, posterior rectangular ; disk channelled, and on each side the channel longitudinally elevated; sides luteous; posterior margin reflexed; elytra very minutely and thickly punctured; lateral margin anteriorly rather pale; legs black; trochanters and cubits dull rufous.

[Belongs to Podubrus:]

340. Tfiephorus (Malthacus) Laficollis Kirby.-Length of body $31 / 2$ lines. A single specimen taken in the Rocky Mountains.

Body black, somewhat hoary with decumbent hairs. Head impunctured, impressed transversely between the eyes; mouth and three first joints of the antennae luteous ; prothorax nearly square, very glossy, impunctured ; elytra less visibly punctured than in the preceding species; legs luteous, thighs brown at the Lase.

['Taken by Agassiz's Expedition to Iake Superior. Belongs to Podabrus.]

341. Teiephorus (Malthacus) Mandibularis Kirby.-Length of body $23 / 4$ lines. Several specimens taken in Lat. $65^{\circ}$.

Body all black, except the red mandibles, somewhat hoary with decumbent hairs. Hind-hend received by the prothorax; eyes very prominent ; antennae longer than the prothorax ; third joint nearly twice the length of the second; prothorax impunctured, scarcely wider than long, all the angles rounded; disk channelled, less elevated on each side ; posterior lateral margins somewhat reflexed; elytra black, minutely and confluently punctured.

[Synonymous with $T$. fraxini Say. Taken in Canada; also by Agassiz's Expedition to Lake Superior.] 
[249.] 342. Telephorus (Brachynotus) Bennetil Kirby.Length of body 6 lines. Taken in Canada by Dr. Bigsby, and in Massachusetts by Mr. Drake.

Body black, hoary with decumbent hairs. Head suborbicular, punctured behind the antennae ; neck rufous ; front, before the antennae, pale yellow ; exterior margin of the nose black ; mandibles yellow at the base ; antennae longer than the prothorax ; prothorax pale yellow, disk elevated with a black irregular punctured spot; elytra minutely and confluently punctured, somewhat dilated externally ; obsoletly tricarinate; legs black; knees rifous.

[Synonymous with Polabrus tricostutus Say; a common species in Canada.

FAMILY LAMPYRIDE.

343. LAMPYRIS CORUSCA Linn.-Length of body $43 / 4$ lines. Taken at New York and Cumberland-house, Lat. $54^{\circ}$. In Canada, by Dr. Bigsby.

Body oblong, pubescent, brown-black. Nose and mouth elongated; prothorax nearly semicircular, disk elevated; a rose-coloured arched streak dilated and yellower anteriorly adjoins the elevated part on each side ; elytra obsoletely carinated, most numerously and minutely punctured.

[Belongs to Ellychnia Lec. Very common in Canada.]

$$
\text { [250.] II.-OR'THOPTERA. }
$$

FAMILY LOCUSTIDF.

344. Locusta leucostoma Kirby.--Length of body $13 \frac{1}{2} / 2$ lines. A single specimen taken in Lat. $65^{\circ}$.

Body obscurely rufous, clouded with darker shades. Upper lip, and large spot of the mandibles, white; palpi reddish, with the two last joints whiter, summit black; antennae as long as the trunk, which on the upper side is subpubescent ; last segment of the prothorax carinated ; tegmina, cinereous, with piceous and rufo-piceous nervures; and at the base is a longitudinal mesal series of black spots; the legs are rufo-testaceous, with the summit of the thighs and the spines black; the posterior thighs above are clouded with the same colour.

[Synonymous with Caloptenus bivittatus Say. This species is found in Canada and the New England States, as far south as Maryland and 
Texas, westward to Nebraska and Minnesota, and northward to Lake Winnepeg.

345. Iocusta verruculata Kirby.-Length of body $123 / 4$ lines A single specimen taken in Lat. $57^{\circ}$.

[251.] Body cinereous, sprinkled with black dots or punctures, and indistinct spots. Head punctured; palpi white at the tip; mandibles piceous; antennae shorter than the trunk, pale, black at the tip and longitudinally concavo-convex; prothorax with an entire longitudinal dorsal ridge, wrinkled, and warty from the wrinkles; tegmina with a reddish tint, irregtlarly reticulated; wings with a black mesal band, and reddish-yellow nervures; abdomen pale underneath.

[Belongs to the genus CEdipoda Iatr. Is taken in Canada and the New England States ; has been found also at Lake Winnepeg.]

FAMILY ACRYDIADE.

346. Acrydium granulatum Kirlyy.-Length of body 5 lines. A single specimen taken in Iat. $65^{\circ}$.

Body black, sprinkled with numberless very minute elevated points or granules. Prothorax cinereous, clouded obscurely with black, threeridged; with middle ridge straight, and the lateral ones curved at the base; rudiments of the tegmina cinereous, ridged, punctured with excavated punctures; nervures of the wings black, those of the costal area white; the four anterior tibia are reddish, obscurely banded or rather annulated with white.

[Belongs to the genus Tettix Latr. Taken by White in Sir J. Richardson's Arctic Searching Expedition, on the borders of the Mackenzie and Slave Rivers, and Fort Simpson. Found also in N. E. States and Minnesota.]

\section{[252.] III.-NEUROPTERA.}

FAMILY AGRIONIDA.

347. Agrion puella Linn.

Variety B. Trunk sea-green, above black with two sea-green longitudinal stripes; abdomen black, sea-green at the base, inscribed with black; legs black alove, underneath sea-green or white; the stigma of the wings is blackish with a transparent margin. 
C. Trunk black and white with two dorsal white longitudinal stripes; legs black; stigna of the wings black; abdomen mutilated.

Both taken in Iat. $65^{\circ}$.

[Hagen (Synopsis of Neuroptera of N. A., p. 98) says that this is "perhaps another species which is inextricable."]

\section{FAMILY PERIIDE,}

348. Perla bicaudata Linn.- - Length of body about $7 \frac{1}{2}$ lines. Several specimens taken in $\mathrm{L}$ at. $68^{\circ}$.

[253.] Body black, hairy. Antennae, tibiae, tarsi, caudal setae, and wings dull testaceous; the vertex consists of a yellowish membranous spot; the joints of the caudal antenniform organs are dark at the tip.

The larva is white underneath, fusco-cinereous above; head and thorax spotted with white, with a pale longitudinal line. More than one species seeins to have passed under the name of Phryganea bicaudata. I will not affirm that the present species is not distinct : but as the specimens were not perfect, I thought it best to consider them as belonging to that type.

[Synonymous with $P$. frontalis Newman. Taken at St. Martin's Falls, Albany River, Hudson's Bay; at 'Trenton Falls, N. Y., and in Ohio.]

$$
\text { IV.-TRICHOPTERA. }
$$

\section{FAMII.Y PHRYGANIDAF.}

349. Limnephilus nebulosus Kirlly. - Length of body 7 lines. A single specimen taken in I,at. $65^{\circ}$.

Body black, hairy with whitish hairs: Antennae are mutilated in the specimen, but the base is black; scutellum testaceous; upper wings testaceous, spotted and dotted with white except the costal area, which is without any of that colour; under wings white with testaceous nervures ; legs testaceous.

350. Limnephilus femoralis Kirby.-Length of body $6 \frac{1}{2}$ lines. Taken with the preceding. thighs.

Very like the preceding species, but paler, with black scutellum and

[Both species are unknown to Dr. Hagen.] 


\section{[254.] V.-HYMLINUPTERA. \\ FIMLY CIMBICIDA.}

351. Cimbrx ramorata Linn.- - length of body 10 lines; expansion of wings 21 lines. A sing!e specimen taken in Lat. $65^{\circ}$.

q. Body very black, hairy. Antenne yellow, brown at the bise ; legs blue-black ; tarsi yellow ; wings hyaline with yellow nervures, brown at the tip, with a brown cloud in the middle areolet adjoining the costa.

352. Trichiosoma Triancilum Kirby.-Length of body 9 lines. A single specimen taken in Lat. $65^{\circ}$. Another was also sent me from Canada by Dr. Bigslyy.

[255.] Body black, shining, covered with soft and woolly whitish hairs, punctured more or less. Head, excluding the mindibles, depressed, orbicular, as wide as the trunk; mandibles crossed, very sharp, black; upper lip subpentagonal, flat with a longitudinal elevation in the middle, hairs on this part black; anterior margin of the nose wavy, emarginate in the middle; antennae with the fourth, fifth, and sixth joints testaceous ; three eyelets behind the antennae arranged in a triangle; eyes oval, prominent; vertex square, marked out by a ridge on each side; trunk subglobose; prothorax with a longitudinal furrow; thighs and coxae black-blue; under a strong magnifier beautifully and most minutely reticulated, which gives them a silky lustre; the rest of the leg is testaceous; the tivo posterior pair of thighs are thicker than the others and armed at the apex with a short tooth on each side, between which is a cavity to receive the shank when folded; tarsi with a sucker underneath at the apex of the four first joints ; wings testaceous with piceous nervures, and a cloud at the tip; abdomen ferruginous with a dorsal triangular black spot, extending from the base towards the apex, but not entering the last segment; the basilar ventral segments are spotted with brown.

[Found in Canada and Colorado.]

353. Trichiosoma lucorum Linn.-Length of body 7 lines ; expansion of wings 15 lines. A single specimen taken in Lat. $65^{\circ}$. 
Body black with a very slight æeneous tint ; glossy, hairy with cinerascent hairs, those of the trunk long. Head orlicular, scarcely so wide as the trunk; upper lip small, convex, orbicular, punctured; antennae black; wings subhyaline with a cloud at the tip; nervures sone piceous and others rufous; thighs black with a very slight tint of blue: posterior pair armed with a tooth ; abdomen short, subuvate, black, covered more or less with short decumbent down; black above, underneath reddish at the tail.

\section{[256.] FAMILY TENTHREDINIDE.}

354. Allantus i.ficnetuma Kirly.-Length of body 6 lines. One specimen taken in Lat. $65^{\circ}$.

Body narrow, black, glossy, without hairs. Head scarcely so wide as the trunk, wedge-shaped; palpi, suborlicular upper lip, emarginate nose, and base of the mandibles, white; apex of the latter rufous; antennae a little shorter than the trunk, nine-jointed, with the third joint longer than any of the others; neck constricted ; tegulae testaceous; wings subhyaline with piceous nervures; legs yellow, with the apex of the tibiae and the whole of the tarsi of the posterior legs, black; abdomen linear, acute at the anus.

This species comes near Allantus ater, but the mandibles are rufous at the apex ; the palpi are whiter; and the legs of a different colour.

FAMILY SIRICIDE.

355. Sirex bizonatus Stephens.--Length of body 18 lines; expansion of wings 27 lines. Taken in Iat. $65^{\circ}$ and in the journey from New York.

[257.] Body very black, covered with innumerable punctures from each of which proceeds a black upright hair. Head narrower than the trunk; mandibles incumbent; palpi rufo-piceous; antennae as long as the trunk, yellow; behind each eye is a large oval yellow eye-like spot perfectly naked and smooth; legs and tips of the thighs yellow; wings yellowish with dark nervures; abdomen with the second, seventh and eighth segments luteous; anal mucro linear, yellow, terminating in a point ; ovipositor black.

The specimens of this species, which Mr. Stephens found near London, might probably have been imported in fir timber from Canada. 
356. SiRkX jrivencus Linn.--Length of body, mucro included, I I lines : expansion of wings 20 lines. One specimen taken in Iat. $65^{\circ}$.

Body black-blue, glossy, punctured rery thickly on the head and trunk, in which from each puncture proceeds a black hair. Head between globose and triangular, very hairy with a naked spot behind the eyes; cheek terminating in a tooth or point as in the other species of the genus; vertex blue-green; antenna black, shorter than the thorax; palpi piceous; trunk sulyglobose, with the central part of the thorax and the part between the four :mterior legs tinted with green; legs rufous with the coxx and trochanters black ; wings hyaline with piceous nervures; abdornen naked, terminated by a subtriangular acuminated mucro or horn; ovipositor piceous.

In this specimen the ovipositor is longer and goes further beyond the anal horn than in the European ones, and the horn itself is more dilated at the base.

$$
\text { [258.] FAMILI FUNID.E. }
$$

357. Fonus Jacclatur Lim.- - ' 'wo specimens taken in Lat. $65^{\circ}$.

The American specimens differ from those of Europe, which also vary, in having the red segments of the aldomen marked with a large black basilar dorsal spot, the former having mostly only a darker cloud. Panzer's figure, however, comes very near the American.

[It is doubtful that the European species occurs in America; they are probably distinct.]

\section{FAMILY ICH.NEUMONIDA.}

358. ICHNEUMON FERRLCATOR Kirby.-Length of body 7 lines. Taken in the Expedition, but no locality stated.

[259.] Abdomen black, rather glossy, very thickly punctured with minute and often confluent punctures. Head transversc, triangular, not quite so wide as the middle of the trunk : anterior margin of the face rounded; palpi reddish ; eyes long, subelliptical ; antenna shorter than the trunk, spirally convoluted; trunk oblong, subcompressed; scutellum subtriangular, rounded at the apex; metathorax armed on each side with a short tooth, with several elevated longitudinal and oblique lines; legs with decumbent whitish hairs, anterior tibix obscurely, and all the tarsi, rufous ; wings embrowned with a rufous tint, nervures darker; abdomen lineari-lanceolate, rufo-ferruginous, with the first joint, which is dilated at the apex, black; footstalk channelled longitudinally on each side. 
FAUIIY CRYPTIDE.

359. Crvptus vibidtorits Fabr.--Length of body, with ovipositor, $5 \frac{1}{4}$ lines; do, without ovipositor, $31 / 2$ lines. One specimen taken in Iat. $54^{\circ}$.

Body black. Head subtriangular, transverse, very minutely and thickly punctured; palpi pale rufous ; face plane with two elevations in the middle; eyes large, oval ; antennæ shorter thar the trunk, rather slender, involute, black with a white band in the usidle; orbit of the eyes behind with a very indistinct white line; trunk oblong, cubical, gibbous, very thickly and confluently punctured except on the back ; tegula white : metathorax armed with two minute teeth on each side, one in the middle and the other at the base, forming the terminal angle, marked out into three areas by elevated lines; legs red with coxa, trochanters, and posterior tarsi black; wings subtestaceous with the larger nervures black; abdomen, excluding the ovipositor, scarcely so long as the trunk; first segrment impunctured, glossy, dilated at the apex, which is subquadrangular ; footstalk that ; second and third segments very large, with their gloss obscured by infinitely minute punctures; ovipositor shorter than the abdomen; borer red.

\section{[260.] (IENUS CRIPTOCENTRLM.}

Head between transverse and globose; face quadrangular, with the anterior margin crenate ; palpi long, filiform; antennæ slender, first joint thick; second minute : third longer than the rest ; trunk ovate-oblong, subcompressed; neck molerately long; scutellum' trapezoidal ; legs slencler, posterior pair elongated; upper wings-apical areolets three; middle four, viz., 2, 2, without a cellule : basilar three; under wingsareolets seven. viz., 4. 3 ; : lblomen sessile, smooth, subcompressed, in the female clubbed at the apex; four first segments longer than the rest, the first curved, rather wider at the apex; the three next are wider than long, the last is ninute and triangular; at the extremity the tail is cleft for the passage of the ovipositor ; this cleft is formed by the turning up of the sides of the last ventral segment; ovipositor very short; the four last ventral segments, at least in the dead insect, project so as to form an elevated ridge in which the ovipositor is concealed.

360. Cryptocentrum lineolatum Kirby.-Plate vi., fig. 1. - Length of body 6 lines. A single specimen taken in Lat. $65^{\circ}$. 
Body very black, somewhat glossy, sprinkled with whitish decumbent hairs. Head subtransverse, hollowed out behind to receive the neck; face with a streak on each side the eyes ; feelers and scape of the antennze on the outside white; antenna slender. black, externally obscurely testaceous, with a white annulet below the middle : trunk compressed ; margin of the collar on each side, tegulae, and two transverse elevated streaks on the scutcllum, white; four anterior legs with the coxae and trochanters. tip of the thigh and under side of the tibiae, white : the thighs, except the tip, testaceous; upper side of the tibiac and tarsi, anci long posterior legs, black; wings hyaline with black nervures ; abdomen sessile, with the last segments dilated for the reception of the ovipositor ; the apical margin of all the segments but the two first is interruptedly white; but in those segments the interruption is not perfect.

\section{[261.] FAMHLY HRACONIDA.}

361. Bracon CROCATOR Kirby. - - length of body without ovipositor 3 lines. A single specimen taken in Lat. $65^{\circ}$.

Body very black, glossy. Head subglobose, with the segment of a circle taken out behind; eyes between oval and round; antennac as long as the trunk; trunk oblong, widest between the wings ; scutellum rather large, rounded at the apex; metathorax obsoletely transversely wrinlled, siuping towards the abdomen; posterior legs rather robust; wings embrowned, middle areolets four, vi .., 3 and I, all quadrangular; stigma very large; abdomen lanceolate-ovate, as long as the trunk, saffron coloured, paler towards the apex ; the three first seginents are enarginate, and marked with two longitudinal faint furrows, the tirst pair being curvilinear ; ovipositor longer than the body, borer red.

FAMILY FORMICID.t.

[262.] 362. Formica SEMIPUNCTATI Kirhy,---Length of body $73 / 4$ lines. Several taken in Journey from New Yo:k to Cumberland-house.

Body black, glossy. Head something wider than the trunk, sw)triangular; antennæ piceous with the scape black; wings cast in all the specimens; scale vertical between the trunk and abdomen, sloping to a thin edge upwards, where it is very slightly emarginate ; abdomen oblong, subcylindrical, minutely punctured with the punctures piliforous; hairs decunibent with those of the margin of the segments and the anus, longer; 
margin of both abdominal and ventral segments membranous, membrane reddish ; base of the three intermediate segments not punctured.

363. Formica FusCA Linn.-Length of body $1 \frac{1 / 4}{4}$ line. One specimen taken in Iat. 65 '.

[263.] q.-Body black, but not intensely, glossy, subcinereous from down. Head triangular, large, much wider than the trunk; antennæ with the scape, the three following joints, and the terminal one, rufous; the other joints are darker; trurik oblong, compressed, anteriorly elevated and wider; the prothorax with the scutellum forming a rhomboid; scutellum large, trapezoidal, subrufous; scale subtriangular, subemarginate; legs rufous; thighs embrowned; abdomen subglobose, more hairy than the rest of the body, especially towards the anus.

\section{FAMILY VESPIDA.}

364. Vespa vUlgaris Linn.--Length of body $61 / 2$ lines. A single specimen taken in Iat. $65^{\circ}$.

[264.] F.-Body black, variegated with yellow. Head and trunk thickly clothed with long woolly down of a grayish colour; face with three yellow spots placed in a transverse line behind the antennae, the two iateral ones subtriangular, the intermediate one subquadrangular, with a reddish cloud on its disk; the nose below the antennac is yellow, inclining to red round the margin ; it has also three black dots placed in a triangle in the disk. the two lower ones being very minute; the vertex of the nose is also black; the mandibles are yellow with black tips; on the outside the orbit of the eyes is reddish-yellow; the trunk is black underneath; above the posterior upper margin of the collar, the tegulae which cover the base of the wings, and a triangular spot underneath them, are yellow; on the metathorax and scutellum are six yellow spots placed in a double series, the upper and lower pairs being subtriangular, and the intermediate pair crescent-shaped; the thighs are black at the base, but their apex, and the rest of the leg, and a small triangular spot on the inner side of the four posterior trochanters, are yellow; the wings are yellowish red with red nervures ; the abdomen, except at the base, is less hairy than the rest of the body; it is yellow with all the segments black at the base; though the blackness in the terminal ones is chiefly concealed by the antecedent segments; in all in the middle it projects into a triangle: the four intermediate ones have also ench a round.headed 
small black spot, the connection of which with the blackness of the base is interrupted in the second segment : on the under side of the abdomen the base of the segments is black, and the intermediate ones have each a pair of rather crescent-shaped black spots not connected with the blackness of the base.

[Kirby states that the specimen above described differs somewhat from the European wasps of this species, but he considers it to be merely a variety of the latter. Later authors state that toth $V$. anlgaris and $l$. germanica, European species, are found on this side of the Atlantic.]

365. VESPA BOREalis Kirby.--Length of body $7 t$ lines. A single specimen taken with the last.

[265.] Body black, downy, especially the head and trunk, with gray hairs. Nose trapezoidal, yellow with a black floriform discoidal spot; anterior margin with three sinuses taken out; vertex with a trapezoidal yellow spot just above the base of the antennæ; antennæ black, luteous underneath; external orbit of the eyes and mandibles yellow; lateral margin of the collar, a triangular small spot under each wing, two narrow transverse and internally acute spots on the scutellum, and two similar ones below them on the metathorax, all white; tegulæ white with a brownish spot in the disk ; legs yellow : thighs black at the base ; wings testaceous : al)domen heart-shaped, with the bases of the segments where uncovered, and two dots on each except the first, black; the middle part of the black basal bands projects into a triangular tooth ; the under side is nearly similar, but the projections form a longitudinal stripe.

366. Vespa marginata Kirby.-Plate vi., fig. 2.-Length of body $71 / 2$ lines. Taken in the route from New York, and again in Lat. $65^{\circ}$.

․-Body black, punctured, downy from a mixture of black and gray hairs. Mandibles white with a black margin; palpi reddish; nose white with a flask-shaped longitudinal black spot in the disk; just above the antennae is a bilobed white spot, between which and the eye is a white line, and another external one above it ; amennae short, not much exceeding the head, black with the scape white underneath; in one of the specimens there is a reddish spot underneath on the four or five last joints, which is not discernible in the others ; the external margin of the collar, before each wing, and a small triangular spot on each side of the scutellum, are white; wings embrowned with darker nervures, but the 
costal nervure and tegulac are ferruginous; legs testaceous, black at the base; abdomen with the apex of the dorsal and ventral seginents white; anal segment black with a pair of white spots; the white margin of the dorsal segments receives an intermediate triangular point, and on each side of it a rounded lobe from the black base.

[266.] 367. Vespa maculata Linn.-Length of body ro lines. A single specimen taken in Iat. $65^{\circ}$.

[As this insect, commonly known as the "White-faced Hornet," is so abundant in Canada, and has been so often described, it is unnecessary to quote Kirby's description.]

FAMILY PROSOPIDA.

368. Prosoris fillptics Kirby.--Length of body 3 lines. Three specimens taken in Lat. $65^{\circ}$.

[26́7.] Body very black, slightly downy, minutely punctured. Apex of the nose white. whiteness lobed; inner orbit of the eyes below the antennate white; vertex channelled below the eyelets ; antennae scarcely longer than the head; the projecting lobes of the collar terminate in a white tubercle : base-covers piceous; wings hyaline with dark nervures; metathorax longitudinally wrinkled ; posterior tibiae annulated at the base with white; abdomen rnore glossy than the rest of the borly, almost naked, and scarcely punctured ; it is narrower and more elliptical than in any other known species of the genus.

[This species and another, $P$. affinis Smith, are found in Canada.]

FAMIIY ANDRENIDA.

369. Halictus rubicundus Stephens, - Length of body 5 lines. Four specimens taken, locality not stated.

o.--Body black, downy. Head suborbicular, down grayish; space between the eyes broad ; down on the thorax thicker, ferruginous ; basecovers rufo-piceous; wings subhyaline; nervures and stigma testaceous; post-costal nervure black; legs thickly set with yellow hairs which shine like gold; tarsi testaceous; abdomen elliptical, downy with decumbent hairs ; margin of the segments fringed with white hairs, the two first subinterruptedly; the ventral segments are similarly fringed, but the hairs are shorter. 
370. Halictus crassiconnis Kirly.---Length of body 3 lines. A single specimen taken in Lat. $54^{\circ}$.

[268] + .- This little insect is so extremely like Halictus lae is, that at first 1 vegarded it merely as a variety of that species, but upon a closer inspection they appear to the distinct. In H. crassicarnis the antennae are proporticnally more robust, but the principal difference lies in the sculpture of the thorax. In $H$. levis that part is visibly punctured with scattered punctures, but in the insect 1 am describing, under a common lens, the punctures are scarcely discernible, but under at higher power, besides a slight channel drawn longitudinally, innumerable very minute punctures appear. In the former also the stigma of the upper wings is piceous, while in the latter it is testaceous. In other respects they are perfectly similar.

371. A.NDRENa IMPUNCTA Kirby.-Length of hody $5 \% \frac{1}{2}$ lines. A single specimen taken in the Journey from New York to Cumberlandhouse.

9.--Body black, clothed with rather long whitish hairs, especially the face below the antennae; hairs of the thorax rufescent ; wings subhyaline a little darker at the tip ; nervures testaceous, post-costal black; brush of the posterior tibia white: abdomen impunctured with the hairs of its ariterior half white; the other hairs above and below black.

372. Andrena varians Ress. - Length of body $5 \frac{1}{2} 2$ ines. Three specimens taken, locality not stated.

[269.] 9 .-Very like the species just described, but the head is clothed with black hair ; that of the thorax and base of the abdomen is tiwny-red ; the brush of the posterior tibia is changeable, as the site varies, from black to white; the hairs of the under side of the body and of the last abdominal segment above are black, except those on the posterior thighs forming the flocculus, which are whitish, as are those of the anterior part of the abdomen.

FAAILY NOMAUIUA.

373. Nomada Americana Kirly.--Plate vi., fig. 3.-Length of body $4 \frac{1}{2}$ lines. A single specimen taken in Lat. $65^{\circ}$.

Body dark-ferruginous. Thorax with a longitudinal mesal black line, less distinct on the metathorax; breast with a black spot on each side : 
wings, as in the rest of the genus, embrowned with a white spot near the tip; thighs black at the base on the under side; first segment of the abdomen black at the base, and, with the second and third, brown at the apex.

This is the only American Nomadel I ever saw, and Fabricius describes none from that country. It comes near Nomada ruficornis and striata, but it has only a single biack stripe on the thorax.

[1)r. Packard states that these Cuckoo-bees, the Nomada, are very numerous in America.]

\section{[270.] HAMII.Y CHELOSTOMIDAE.}

374. Chelostoma albifrons Kirby. - Length of body $4 \frac{1 / 2}{2}$ lines. A single specimen taken in Iat. $65^{\circ}$.

o.-Body black, thickly punctured. Mouth bearded with white; mandibles carinated alsove, armed witn two strong terminal teeth; nose square, flat, clothed with decumbent silver pile; antenne filiform ; scape black; the other joints are rufo-piceous underneath; trunk very hirsute with white or subcinereous hairs; wings a little embrowned, with black veins and base-covers; legs hairy ; abdomen subcylindrical, hirsute with black hairs, incurved with the apex of the four intermediate segments fringed with white hairs; anal joint with a concavity above, obtuse ; last ventral segment forcipate, rufo-piceous

FAMILY MECIALHILID.F.

375. Megachilf. maritima Stcphens. - Length of body 7 lines.

[27r.| Body black, pubescent, thickly and minutely punctured. Mandibles very large, triangular, protended, not crossing each other, armed with four terminal teeth; face between the eyes thickly clothed with brown hairs, which grow tawny towards the mouth; antennæ filiform ; back of the trunk clothed with brown hairs less thickly in the disk ; wings a little enıbrowned, especially at the apex ; nervures dusky ; base-covers piceous; legs hairy with pale hairs; abdomen subovate with the three last segments fringed with pale hairs intermixed with black; the ventral hairs are tawny, paler towards the base, and darker towards the apex. 
FAMILY ANTHOPHORIDE.

376. Anthophora bomboides Kirby.-Length of body 6 lines. A single specimen taken in Lat. $65^{\circ}$.

Body black, thickly punctured, clothed like that of a humble-bee with dense pallid hairs. Head triangular, upper lip subquadrangular, white with a black dot at each upper angle; nose white, naked; a bunch of whitish hairs conceals the base of the antennæ; antennæ filiform, scarcely longer than the head; vertex with some black hairs thinly scattered; occiput fringed with whitish ones; trunk subglobose, set with longish white hairs; hairs of the legs mostly black; tarsi piceous; the first or dilated joint is armed with a strong and sharp tooth on the inner side at the base; wings subhyaline with black nervures; abdomen between globose and triangular, with the three first dorsal segments clothed with long whitish hairs, and the tail and ventral segments with black.

\section{[272.] FAMILY BOMBIDE.}

377. Bombus sylvicola Kirby. - Length of body 7 lines. A single specimen taken in Lat. $65^{\circ}$.

General hirsuties of the upper side of the body yellowish. Head with a tuft of the same colour below the antennæ, and another at the vertex; trunk with a broad 'lack band $r$. iween the wings; hairs of the thighs yellowish ; those of th ? tibix black ; tarsi more or less covered with short decumbent pale hairs; wings somewhat embrowned, with black nervures ; abdomen with a broad, mesal, ferruginous band.

378. Bombus borealis Kirby.-Length of body 8 lines. Several taken with the preceding.

[273.] Body clothed underneath with black, above with tawny, hairs. Face and vertex with a tuft of yellowish ones ; thorax, between the wings, with a black hairy band; wings somewhat embrowned with black nervures; legs black; abdomen above with a thick coat of tawny hairs palest at the base; anus black.

379. Bombus terricola Kirby.-Plate vi., fig. 4.-Length of body 9 lines. Taken with the preceding.

9. This species approaches very near to $B$. terrestris, but the whole upper surface of the abdomen is clothed with yellow hairs, with the exception of the first segment, the hair of which, and a band near the anus, are 
black; the extremity only of the latter is dirty-white; there are a few yellow hairs on the metathorax ; and the wings are embrowned. In $B$. terrestris the abdomen is black, with a yellow band, and the two last anal segments are white; there are no yellow hairs on the metathorax, and the wings are much clearer.

380. Bombus Derhamellus Kirby. - Length of body 8 lines. Taken with the preceding.

q. Body hairy, black. Head with a tuft of yellowish hairs on the vertex ; thorax yellow, black between the wings; wings more eiubrowned than in the male; abdomen yellow at the base with a black posterior band ; anus ferruginous.

[274.] 381. Bombus praticola Kirby. - Length of body 7 lines. Taken with the preceding.

i. Body black, clothed above with yellowish hairs. Head with a tuft of yellowish hairs below the antennæ, and on the vertex; thorax black between the wings, which are embrowned; legs with yellow hairs at the base ; anterior half of the abdomen yellow, posterior ferruginous.

382. Bombus virginicus Linn. - Length of body $81 / 2$ lines. Locality uncertain.

\%. Hairs of the body in general black, except a tuft on the vertex behind the antennæ, the anterior and posterior extremities, and sides of the thorax, and the first segment of the abdomen, which are clothed with yellowish hairs; between the wings the thorax is black; the tarsi are rufous; the wings are rather embrowned, most so at the apex; nervures black.

\section{[275.] VI. HEMIPTERA.}

FAMILY PENTATOMIDE.

383. Pentatoma Carnifex Fabr. - Length of body $21 / 2$ lines. Several specimens taken in the road from New York to Cumberland-house.

Very near $P$. oleracea, and probably its American representative. Body black, a little bronzed; grossly and thickly punctured, the punctures on the upper surface the deepest. Head subtrapezoidal ; promuscis pale in the middle; antennæ longer than the head; prothorax wider than long, 
with the lateral angles obtuse; signed with a sanguine cross, the arms of which extend from angle to angle; lateral margin, as well as that of the hemelytra and abdomen, white; scutellum longer than the thorax, obtuse with a subtriangular sanguine spot on each side near the apex; penultimate ventral seginent of the abdomen margined with white; membrane white.

[276.] 384 . Pentutoma variegata Kirby. - Length of body 3 lines. A single specimen taken in the road from New York to Cumberland-house.

Upper surface of the body punctured. Head, excluding the prominent eyes, subtrapezoidal, black, with the margin below the eyes, white; promuscis extending to the base of the hind legs, pallid, black at the tip; antennæ black; prothorax transverse with lateral angles obtuse; pallid with a tint of flesh-colour, especially at the angles, with a broad anterior and narrow posterior black band, both abbreviated on each side, and the latter almost divided into two; scutellum an isosceles triangle, obtuse at the apex, black with the lateral margin pallid; hemelytra black with a pallid lateral margin, membrane embrowned ; underside of the trunk black spotted with pallid and sanguine, punctured; tibia and apex of the thighs black; base of the thighs sanguine; abdomeir below punctured at the sides, sanguine, with a large black discoidal spot, rather nearer the anus; nearly divided into two; on the sides and at the base naked, but a quadrangular space of the inner side of each division is covered with decumbent subcinereous pile.

N. B. The antepectus is entirely pallid, but the socket, if it may be so called, of the legs is redder at the margin than the rest.

385. Pentatoma trilineata Kirby.-Plate vi., fig. 6.-Length of body 3 lines. One specimen taken with the preceding.

[277.] Body underneath and the head black, a little bronzed; thickly punctured with rather deeply impressed punctures; antennæ reddish at the base, with the two last elongated and incrassated joints black ; prothorax black anteriorly, posteriorly lurid with the lateral margin and an intermediate longitudinal impunctured line, which extends nearly through the scutellum, white; the scutellum has also a white linear spot and dot on each side at the base; the punctures of the thorax, scutellum, and hemelytra are black; the membrane of the latter is white; the legs and sides of the breast are lurid spotted or punctured with black; the elevated 
basilar portion of the bed of the rostrum is concave and has a semicircular outline, and its margin, viewed under a strong magnifier, is minutely serrulate.

\section{FAMILY EDESSIDÆ.}

386. Edessa nebulosa Kirby.-Length of body 3-4 lines. Three specimens taken in the journey from New York to Cumberland-house, and in Lat. $65^{\circ}$.

Body pale yellowish, sprinkled with black impressed punctures, most numerous and largest on its upper surface, which is clouded with reddishbrown, or blackish shades; the antennæ are of a reddish-yellow; the lateral angles of the prothorax are more acute than in the Pentatoma; the scutellum is acuminate or attenuated at the apex; the lateral margin of the abdomen has a black spot on each segment, which sometimes appears on the ventral segments.

VARIETy B. Smaller, with the ventral segments of the abdomen rufescent, and the clouding of the upper surface of the body blacker ; the thorax also is black posteriorly.

\section{FAMILY CAPSIDE.}

387. Miris punctulatus Kirby. - Length of body 3 lines. Two specimens taken in Lat. $65^{\circ}$.

[278.] Body oblong, pale, somewhat lurid with a very slight tint of green. Head triangular, impunctured ; eyes a little embrowned, prominent ; antennæ as long as the prothorax, subtestaceous with the two last joints and the underside of the first black ; thorax, scutellum and hemelytra very minutely punctured; a small portion of the prothorax adjoining the head is separated from the rest by an impressed sinuous line and is not punctured ; legs pale ; abdomen subpyramidal, black above, pale underneath.

388. Miris ventrl.tis Kirby.-Length of body 3 lines. Taken with the preceding.

Very similar to $M$. punctulatus, and perhaps only a variety, but the hemelytra are faintly clouded with black, the underside of the abdomen is dusky with two longitudinal reddish spots or stripes.

FAMILY ACANTHIADE.

389. Aradus tuberculifer Kirby.-Plate vi., fig. 5. Length of body $33 / 4$ lines. A single specimen taken with preceding. 
[279.] Body dull black, very flat. Head with the nose prominent and obtuse, and the front armed with a sharp tooth on each side; antennæe black with the second joint rufous all but the tip; the last joint white at the tip; prothorax with a short anterior truncated lobe, widest in the middle where the sides form a rounded angle; enarginate posteriorly ; edge very minutely serrulate; six longitudinal ridges occupy the disk of the thorax, the two external ones are abbreviated and rather obtuse; scutellum with a reflexed margin, and bearing on its disk a large subhemispherical tubercle; hemelytra reticulated with cinereous, especially the membrane ; abdomen with a broad margin, and the last segment bilobed with incurved lobes.

This species appears to be related to $A$. depressus and elevatus Fabr., and to $A$. quadrilineatus of Say.

390. Aradus affinis Kirby. - - I.ength of body $2 \frac{1}{2}$ lines. Several taken with preceding.

Extremely similar to A.tuberculifer, but much smaller. Antennæ entirely black ; prothorax not extended anteriorly, so as to form a lobe; lateral abbreviated ridge more obtuse, resembling a tubercle; margin of the abdomen with a white point at the apex of each segment; anus not lobed.

\section{FAMILY REDUVIADE.}

[280.] 391. Reduviolus inscriptus Kirby.-Plate vi., fig. 7.Length of body 3 lines. A single specimen taken with preceding.

Body of a pale or yellowish white, lineari-oblong, widest posteriorly. Antennæ shorter than the body, rufous, three last joints very slender; head and prothorax streaked and dotted with black; with the anterior lobe of the latter constricted next the head, separated from the posterior by an impressed sinuated black line; scutellum black with two pale longitudinal elevations, thickest anteriorly; hemelytra with the nervures whiter than the rest of their substance; with three blackish discoidal dots arranged longitudinally from the middle to the membrane; thighs dotted with b!ack, the anterior pair being incrassated and thicker than the intermediate, and these than the posterior, which are not incrassated; back of the abdomen black, with a white lateral margin, underneath with three longitudinal black stripes.

[281.] 392. ChIROLEPTES RAPTOR Kirby.-Length of body nearly 4 lines. Two specimens taken in the road from New York to Cumberland-House. 


\section{$13^{8}$}

Body black and shining. Heaa subrhomboidal, connected with the prothorax by a long cylindriral and transversely wrinkled neck, which altogether gives the animal a serpentine aspect; legs pale; shoulders much incrassated, blackish at the tip, armed below with several strong spines; cubits with a single internediate one; prothorax bell-shaped, black, dull from inconspicuous pubescence;-scutellum dull, white at the tip; hemelytra dull from pubescence, blackish-brown, with pảer lines which extend into the membrane; lateral margin white; abdomen black, with the ventral lateral margin white.

This species approaches very near to Say's Reduvius raptorius, but it is distinct.

[282.] 393. Nabicila subcoleoptrata Kirby. - Length of body 4 lines. Taken with the preceding.

Body apterous, black, without any gloss. Head subtriangular, antennæ rufous; thorax bilobed, first lobe thrice as long as the last, bell-shaped; last a little wider than the first, flattish ; hemelytra a little shorter than the abdomen, brownish-black, punctured; lateral margin obscurely rufous ; membrane scarcely differing in substance or colour from the rest of the hemelytrum; legs rufous? abdomen obtusangular underneath.

\section{FAMILY HYDROMETRIDA.}

394. Gerris Rufo-scutellata Latr.--Length of body $61 / 3$ lines One specimen taken in Lat. $65^{\circ}$.

Body underneath black, covered with silver pile. Head brown-jlack, subpilose; two first joints of the promuscis black and robust, the remainder rufous and more slender; antennae rufous with the last joint black; eyes large, subhemispherical, brown; prothorax dull-ferruginous, with the lateral margin, a dorsal subelevated line, and the scutellum, paler; legs rufous, pale at the base; hemelytra dull-ferruginous, with the lateral margin and nervures black; the bead that forms the lateral margin of the abdomen, and the two last segments, are rufous; the anal spines are very little shorter than the tail.

[283.] 395. GERRIS LACUSTRIS Linn.-There were three pupæ of this species taken, which do not appear to differ from the European specimens. 
FAMILY CORIXIDE.

396. Corixa Striata Linn.-Length of body $3-31 / 4$ lines. Many specimens taken with the preceding.

Body yellowish, depressed, naked, smooth. Head inflexed, obtuse; eyes brownish, triangular; antennae inserted before the eyes under the lateral margin ; scape incrassated ; remaining joints together are setiform; prothorax subtriangular, with the hemelytra, brown, streaked transversely, with irregular yellow streaks; epipleura not streaked, pale-yellow ; breast black, spotted with yellow on the sides; legs yellow ; anterior and posterior tarsi natatory; the latter longer than the tibiae; abdomen with the first ventral segment, and an abbreviated basilar band of the second, black.

VARIETy B. With the first joint of the posterior tarsi black at the tip. This may be a distinct species; there were seven specimens distinguished by a black annulet surrounding the terminal half of the first dilated joint of the tarsus in question.

[284.] 397. Corixa carinata Kirby. -Length of body 4 lines. Two specimens taken with preceding species.

Body yellow underneath, embrowned at the insertion of the legs. Head yellow; front broad and flat; labrum transversely tricarinate ; occiput obtusangular ; vertex with an obsolete longitudinal ridge issuing from the angle of the occiput; prothorax with a longitudinal intermediate ridge, transversely streaked with yellow and brownish.black; hemelytra sprinkled, and towards the base almost streaked, with black and yellow. In other respects this species resembles $C$. striata.

398. Corixa planifrons Kirby. - Length of body 4 lines. Two specimens taken with the preceding.

This species differs from the preceding in having the under side of the body black, with two pale spots on each side of the breast, and the anal half of the abdomen pale-yellow. The head is yellow, the vertex is ridged longitudinally and separated from the front by a transverse curvilinear ridge ; and from which the anterior part of the face is inflexed, plane or slightly concave; in other respects this species exhibits exactly the same characters with $C$. carinata. They may perhaps be sexual varieties. 
[285.] FAMILY NOTONECTIDE.

399. Notonecta insulata Kirby. - Length of body $62 / 3$ lines. A single specimen taken.

Body underneath black, above yellowish. Head yellowish, with a brownish longitudinal stripe between the cyes, which are reddish; scutellum very black, velvetty ; hemelytra with the lateral margin brown spotted with yellow ; the posterior half of the henelytra is brown anteriorly, blackbrown in the middle, fuliginous at the apex; in this darkened portion anteriorly is a yellowish triangle connected with the last marginal spot, and posteriorly is a white kidney-shaped spot followed by the sooty apex; breast very hairy with longish fuliginous hairs; legs yellowish.

\section{HOMOPTERA.}

FAMILY CERCOPIDE.

400. Cercopis marginella Fabr.-Length of body $3 \frac{1}{4}$ lines. Taken with the preceding, and at Carlton-house in April.

Body black, dotted and inscribed with white. Hemelytra embrowned; nervures black; lateral margin sanguine ; margin of the abdomen edged with white.

[286.] VIII. LEPIDOPTERA.

FAMILY PAPILIONIDAE.

401. Papilio turnus Linn.-Taken in Canada by Dr. Bigsby. [It is, of course, quite unnecessary to repeat Kirby's description of this very familiar butterfly.]

[287.] 402. Colias edUSA Fabr,-Several specimens from North America. [This species is, no doubt, $C$. eurytheme Boisd., which is quite common at Sault Ste. Marie and other localities in the North-west. For aescription and admirable figures see Edwards' "Butterflies of North America," vol. i., part iv.] 
[288.] 403. Ponta casta Kirby.--Plate iii., fig. I.--Three specimens titken in Lat. $65^{\circ}$.

[A well-known valicty of Pieris oleraca Boisd.; quite common in Canada.]

\section{[289.] FaMHY NYMPHALIUA.}

40.4. Meliteda selenis Kirby.--Taken in North America. [Is our common $M$. tharis.]

405. Arginnis cybel.e Fabr--Taken in Canada by Dr. Bigsby. [Common in Canada; for description and figures, and for a full account of the differences that distinguish this species from A. aphroulite, No. 407 , see Fdwards" "Butterflies of N. America," Part i.]

[290.] 4oG. Arginis myrina Fabr.-Taken in Canada by Dr. Bigsby: [Quite common in Canada and well-known to collectors.]

407. Argynnis aphrodite Fabr.- Taken in Canada by Dr. Bigsby. [Quite common; see our note on $A$. cyliclc above.]

[291.] 408. Argynnis freya Esper:-Expansion of the wings I t/2 inches. Three specimens taken near Cumberland-house, I at. $54^{\circ}$.

Stalk of the antennæe yellow with a large compressed dark-brown knob, red underneath at the base and tip ; wings tawny, dark-brown at the base, with a narrow black band occupying the posterior margin, followed by a series of black arrow-headed spots; next to which in the primaries is a zigzag angular discoidal black band, and at the anterior margin five transverse spots of the same colour; the underside of these wings is tawny variegated with black and white spots and lines; the secondaries are underneath reddish-brown variegated with white and yellow spots and bands, with a discoidal arrow-headed white spot in the centre; the fringe of the wings is alternately white and yellow.

[A decidedly northern insect; has been taken in Labrador.]

\section{[292.] FAṂILY VANESSID.モ:}

409. Vanessa C-argenteum Kirly.-Plate $\dddot{i i i}_{i}$, figs. 6 and 7 . Expansion of the wings 2 inches. A single specimen taken in Lat. $54^{\circ}$.

Antennæ brown above; pale below; knob pale at the tip; wings angular, cut out into sinuses which are dentated ; primaries above urangetawny, with five black round spots forning a right-angled triangle with 
each other; two triangular costal bars and posterior margin black; above the black marginal band is a series of paler tawny triangular spots ; underneath the wings are veined, marbled and clouded with black, brown, and cinereous; the primaries have a very broad paler band near the margin; secondaries above dull-orange, at the base with a black spot or two near the anterior margin; the other half is black with a transverse series of triangular pale spots, the interior ones being nearly obsolete; the disk is inscribed with a slender silver somewhat obtusangular $\mathrm{C}$, with the concavity towards the anterior margin.

[Synonymous with our common Grapta progne Cramer.].

4 ro. Vanessa furcillata Say.-Taken in Canada by Dr. Bigsby. Common in the N. West Territory and the vicinity of Fort William.

[Synonymous with $V$. Milberti Godt, a common and very familiar butterfly throughout Canada. For description and figure see Say's Am. Entomology, vol. ii., pl. 27.]

[293.] 4II. VANessa antiopa Linn.-Taken in Canady by Capt. Sheppard. [Too common in Canada to require any description.]

[294.] 412. Vanlessa atalanta Linn.-Several taken in Canada. [Quite common ; for description see Harris' Insects of Mass., p. 294.]

[295.] 4I3. Crnthia cardul.-Linn.-[Another very common butterfly ; see Harris' Insects of Mass., p. 29r.]

[296.] 4I4. Cynthia huntera Drury.-[Alnost as common as the preceding species; see Harris' Insects, $\mathbf{p}$. 292. This and the two $w$ ceding species are now included in the genus Pyrameis Hubn.]

\section{[297.] FAMILY HIPFARCHIADA.}

415. HipPaRchIA NEPHELE Kirby.-Expansion of the wings $2 \frac{1}{2}$ inches. Taken in Canada by Dr. Bigsby.

Antenne brown annulated with white, rufous at the end; knob slender; wings brown ; primaries both above and below with a paler sub. marginal broad band including two eyelets; the upper ones surrounded by a paler atmosphere, with a black iris and white pupil; on the under side the atmosphere of the eyelets is more distinct and forms a kind of glory round them; the pupil is snowy-white with some blue scales scattered 
round it ; the under side of both wings, above the band, is marbled with transverse deeper coloured streaks; the secondaries are dentated but not the primaries, which at the margin have two transverse biack parallel lines ; in the former there is anteriorly a costal paler bar, and the posterior half of the wing is paler ; between the bar and the marginal paler band are three minute eyelets, with a black iris and bluish pupil, arranged transversely in a triangle; and three more similar ones arranged oblicuely, the external one minute, in the paler part, the internal one pointing to the anal angle.

[Quite common in Canada ; included in the genus Satyrus Westwood.]

[298.] 4i6. Hipparchia discoidalis Kirby.-Plate iii., figs. 2, 3. Expansion of the wings $13 / 4^{-2}$ inches. Several specimens taken at Cumberland-house, Lat. $54^{\circ}$.

Body brown. Antennæ annulated with white; wings very entire, brown ; costa spotted with gray; a triangular obscure reddish-tawny discoidal stripe extends from the base to the posterior margin of the primaries, and is discoverable also on the under side where the wing is faintly clouded with gray at the tip ; the secondaries underneath are indistinctly marbled and clouded with gray or whitish scales; fringe whitish and brown alternately.

[A northern species; has been taken at Fort Simpson, and in Alaska.]

FAMILY LYCANIDA.

417. 'Hecla augustus Kirby.- Plate iii., figs. 4, 5--Expansion of the wings $I$ inch. Taken in Iat. $54^{\circ}$.

Antennæ annulated with white; knob elongated; wings dusky black with a dull ferruginous disk ; fringe alternately black and white; secondaries underneath black at the base; at the apex dusky ash.coloured, with a transverse series of about eight black spots, rudiments of which appear on the same surface of the primaries.

Named after the Esquimaux Augustus.

[Taken in Canada, the New England States, and New York.]

[299.] 4r8. Lycana doRCas Kirby.-Plate iv., fig. 1.-Expansion of the wings $I$ irch. 'Taken in Lat. $54^{\circ}$.

Body black above, white underneath. Antennæ black, annulated with white ; knob tipped with orange ; wings brown with a reddish tint, under- 
neatl tawny ; primaries with an angular band formed of faint black spots; behind these nearer the costa is a black bar, above which are two more spots; between the band and the posterior-margin are three more black spots arranged transversely, anu above the base are three spots forming a triangle; the secnndaries have a slight sinus near the anal angle, the fringe of which projects so as to assume the appearance of a short tail ; across the cisk runs an angular band formed of faint black spots, above which is a crescent of the same colour ; at the anal angle is an orange coloured angular bar, or abbreviated band; underneath, these wings have several indistinct black dots, the three external ones of which form an obtuse angle with the four internal ones.

This species seems the American representative of $L$. Phlcas, but its colour is much less vivid.

[Belongs to the genus Chrysophanus Hubn.; it is probably identical with $C$. Americana D'Urban.]

419. Polvommaus lecia Kirby.-Plate iii., figs. 8, 9.- Expansion of the wings $\mathrm{I}$ inch. One specimen taken with the preceding.

[300.] Wings above silvery-blue, terminating, especially at the posterior margin, in a very slender black line ; fringe white barred with black ; primaries underneath ash-coloured mottled with white; in the disk is a black crescent and a curved macular band, consisting of, mostly, oblique black crescents edged with white, especially on their under side; the wing terminates posteriorly in a broadish, brown band, formed chiefly by obsolete eyelets; the secondaries are brown; underneath spotted and striped with black and white; towards the posterior margin the white spots are arranged in a transverse band parallel with it ; and, as in the primaries, the wing terminates in several obsolete eyelets.

[Figured by Harris (Ins. Mass., figs. 105, 106) under the name of $P$. psetidargiolus. Not uncommon in Canada and the Northern States.]

\section{FAMILY HESPERIADE.}

420. Hesperia Peckius Kirly.-Plate iv., figs. 2, 3.-Expansion of wings $\mathrm{I}$ inch and $1 / 2$ a line. Taken with the preceding, and also by Prof. Peck.

Body brown, paler on the under side. Antennæ rufous above, below the joints have a patch of white scales; knob fusiform, hooked; wings above tawny-brown, with an articulate angular band, common to both 
wings, of pale yellow ; primaries striped and streaked with the same colour near the base, and in the costal area; underneath the wings are paler; the primaries have nearly the same marks as above but more conspicuous ; on the secondaries the angular band is surmounted by another irregular spot, so as to form two contiguous spots, or rather one large irregular didymous one.

[Quite common in Canada.]

\section{[3OI.] FAMILY ZYGENIDE.}

421. Alypia Mac Cullochil Kirby.-Plate iv., fig. 5.-Expansion of wings $\mathrm{I} / \mathrm{z}$ inch. Taken in Nova Scotia by Dr. Mac Culloch, and in Canada by Dr. Bigsby.

Body and wings very black. Orbit of the eyes externally clothed with white hairs ; base-covers or tippets whitish ; primary wings with three very white spots, one near the base oblique, obversely wedge-shaped, divided into two by a longitudinal black line; next, at a little distance from the anterior margin is a subtrapezoidal, small, white spot, between which and the posterior margin is an articulate band, abbreviated at each end, of the same colour, consisting of six spots divided by black lines; the same spots distinguish the under surface of these wings, and besides there is a whitish longitudinal one in the costal area; in the secondaries are also three white spots on both surfaces, viz, a large rectangular one near the base divided longitudinally into four; a longitudinal undivided one at the anterior margin; and an articulate posterior abbreviated band, divided into five spots ; the longitudinal costal streak may almost be regarded as forming a sixth, as the lower end is parallel with the last spot of the band; the four anterior legs are externally covered with long orange coloured hairs, which character is slso found in A. octomaculata.

\section{FAMILY SPHINGIDE.}

422. Smerinthus Cerisyi Kirby.-Plate iv., fig. 4.-Expansion of the wings $23 / 4$ inches. Taken in North America, locality not stated.

[302.] Body ash-coloured; thorax with a large trapezoidal brown spot dilated next the abdomen; primaries angulated, ash-coloured, with a transverse series of brown submarginal crescents in a paler band, between which and the posterior margin is another obsolete paler one; above the crescents is a straight whitish band, and a linear angular forked one under the internai sinuses of which the wings are clouded with dark brown; 
underneath the above markings of the wing are very indistinct; the secondaries are rose-colour, paler at the costal and posterior margins; underneath they are dusky-cinereous, with a whitish band coinciding with that of the primaries, a transverse series of crescents and a dentated brownish band, all rather indistinct; but the most conspicuous character of the secondaries is a large eyelet situated at the anai angle, consisting of a black pupil, nearly but not quite surrounded by a blue iris, and situated in a black triangular spot or atmosphere, which extends to the anal angle, and is surmounted by soice blue scales; the abdomen above is dusky ash-coloured.

This insect appears to be the American representative of $S$. ocellatus, from which, however, it differs considerably. It comes very near to $S$. geminatus (Say Am. Ent. i., t. xii.,) but in that the eyelet has two blue pupils.

423. Deilephila intermedia Kirby.-Expansion of wings $2 x / 2$ inches. Taken in North America.

This species is intermediate between $D$. Euphorbice and $D$. Galii, which last it most resembles, but the anterior portion of the mesal stripe of the primary wings is pale rose-colour; the fringe of their inner margin, and of the posterior of the secondaries is white ; there is no series of white dots on the back of the abdomen and the ventral segments are fringed at the apex with white hairs. This description was taken from an old specimen apparently somewhat faded.

[Is probably identical with $D$. Chameenerii Harris, a common species in Canada.]

\section{[303.] FAMILY SESIADE.}

424. Sesia RUficaudis Kirby (Sphinx pelasgus Cramer).--Expansion of the wings $2 \frac{1}{8}$ inches. Taken in Canada by Dr. Bigsby, and in New Jersey by Mr. Drake.

Body yellow-olive, underneath pale-yellow. Antennæ black; primaries reddish-brown, hyaline in the disk, with the hyaline part half divided towards the base with a costal bar, covered with yellow-olive hairs at the base; underneath the costa, the posterior margin and the nervures are dark ferruginous; there is also a yellow stripe on the inner side of the base; secondaries hyaline in the disk; base externally and costa yellow ; internally the base is ferruginous; underneath the dark part of the wing 
is ferruginous, and the base pale-yellow ; two first segments of the abdomen yellow-olive, two next black, the rest ferruginous with pale-yellow lateral spots.

This species appears to be the American representative of Sesia fuciformis, which it greatly recembles, but differs in the colour of the tail and the base of the secondaries.

[This description is not sufficiently definite for the determination of the species.]

\section{FAMILY LITHOSIAD隹.}

425. Callimorpha Parthenice Kirby.-Expansion of the wings $\mathbf{I} 3 / 4$ inch. Taken in North America.

[304.] ¿. Antennæ black, bipectinated; thorax flesh-coloured with two anterior, and three posterior, oblong, black spots, the latter being the largest ; primary wings black, with the so-called rivulets pale with a slight pinkish tint ; the main streams, especially towards the apex of the wing, form several islets, most of which are divided by slenderer ones which do not appear on the under side of the wing ; the secondaries are of the colour of red lead, with five black spots towards the posterior margin, the intermediate three forming a macular band, above which is one smaller one and below it another ; underneath there is also a small spot, at the costal margin, above the others.

LA species of Arctia, probably identical with A. airgo Linn.; not uncommon in Canada.]

426. Callimorpha virguncula Kïby.-Plate iv., fig. 6.-Expansion of the wings $1 \frac{1}{2}$ inch. Taken in Canada by Dr. Bigsby.

Head pallid ; orbit of the eyes, and the mouth, black ; antennæ black, serrato-pectinate ; thorax pallid, with five lanceolate black spots, the posterior ones being the largest; primary wings black, with pallid rivulets, which are formed by the scales that clothe the nervures, and produce the rays at the apex of these wings, where the lines are traversed by a transverse, angulated band; underneath they are pale, with the black parts less distinct, except at the apex; there is a black spot in the disk near the costal margin ; the secondaries are orange-tawny, spotted at the apex with black; abdomen tawny above, below pale, with a dorsal, and on each side a double, lateral, black, macular stripe ; irunk underneath black, with pale 
hairs internixed ; legs black; tibix pale above ; thighs with a pale spot at the base and apex.

This is nearly related to the precedinir species, but is much smaller; and the painting and spotting of the wings differ materially.

"[A species of Artia; taken in Canada.]

[305.] 427. Lithosia miniata Kirby.-Expansion of the wings $1 \mathrm{I} / 2$ inch. Taken in Canada by Dr. Bigsby.

Head, trunk, base and apex of the abdomen, costal and anal margin, mesal forked stripe of the primary wings, and base of the secondary, miniatous or of the colour of red lead; two longitudinal stripes and the space between the apical fork of the primaries, apex of the secondaries, and middle of the abdomen, slate-coloured.

[Belongs to the genus Hypoprepia Hübn. ; not uncommon in Canada.]

FAMILY CTENUCHIDF.

428. Ctenucha Latreillana Kirby.-Expansion of wings $21 / 8$ inches. Taken in Canada by Dr. Bigsby, and in Nova Scotia by Dr. Mac Culloch.

[306.] Body, and primary wings, light-brown. Antennæ and anal hairs black; head and base of the primaries, bright orange ; trunk, back of the abdomen, and outside of the thighs, cyaneous or blue-green ; fringes of the wings white, but in the middle of the posterior margin browu; secondaries short.

[Previously described under the specific name of virginica Charp.; quite common in Canada.]

FAMILY NOCTUIDE.

429. Plusia rectangula Kirby.-Expansion of wings $I / 2 \cdot$ inch. Taken in Canada by Dr. Bigsby.

Body cinereous, underneath whiter. Antennæ testaceous; thorax crested? as the scales are mostly rubbed off this cannot however be positively asserted; wings incumbent; primaries with a subcrenate edge; inclining to ash-coloured, clouded with black, with a subramose rectangular somewhat silvery spot, extending from near the base to the middle of the wing ; between which and the apex is a narrow white wavy band, edged 
429. Plusta rectangula Kirly.-Expansion of wings $11 / 2$ inch. Taken in Canada by Dr. Bigsby.

Body cinereous, underneath whiter. Antennæ testaceous; tnn-ax crested? as the scales are mostly rubbed off this cannot however be positively asserted; wings incumbent; primaries with a subcre:ate edge ; inclining to ash-colored, clouded with black, with a subramose rectangular somewhat silvery spot, extending from near the base to the middle of the wing; between which and the apex is a narrow white wavy band, edged with black; and still nearer the margin a zigzag transverse black line; the secondary wings are plicatile, cinercous, and dusted at the apex with brown.

N. B. The silvery rectangular spot in the primary wings of this inser, when they are brought near to each other, forms a quadrangular area very much resembling a picture in a silver frame.

[307.] 430. Plusia Ganna Linn-Expansion of the wings $1 \frac{1}{2}$ inch. Taken in Canada by I)r. Bigsby:

Head, crests of the thorax and abdomen gray; these crests are edged with white and in the anterior ones the margin is formed by a black and white line; abdomen cinereous; antenna above testaceous, underneath white banded with brown; the primary wings are shaded and clouded with black, brown and white, and towards the apex have three indistinct bands, the first white internally abbreviated, the second dark-brown, and the marginal one gray including a transverse series of black crescents; in the disk of the wing is a pallid silvery signature, representing the Creek letter ganma, or the Roman $\mathrm{Y}$, the forked part pointing to the costal margin; from the upper point of the fork a white curving line runs obliquely to the anal margin of the wing near its base; secondary wings light brown, or drab, with the nervures, and posterior margin broadly, darkbrown ; fringe alternately dark and light; underneath the wings are cinereous, darker at the apex.

[308.] 431. Plusia falcifera Kirby.-Expansion of the wings $11 / 2$ inch. Taken in Nova Scotia by Dr. Mac Culloch.

Body gray. Antennæ and thorax, when laid bare, testaceous ; primary wings gray with a faint reddish tint, a broad brown spot, or cloud, almost 
triangular, traverses the middle of the wing, which partly includes, and is partly edged, by a sickle-shaped silvery streak ; the part representing the handle of the sickle being broader than the rest, and sending forth externally near its apex a short branch, which, with the internal apex of the handle, forms a fork; the inner tine, or branch, of which terminate; in a slend. $r$ line running in a curve to the costal margin, where it touches the scutellum; a brown indistinct cloud, or band, also runs obliquely from the anal to the apical angle of the wing; a very minute, pale streak marks it just transversely above the former angle; the posterior margin is slightly indented; the secondary wings are reddish-brown, with an obsolete, pale, submarginai band.

432. Plusia IOTA Linn.-Fxpansion of wings $13 / 4$ inch. Taken in Nova Scotia by Dr. Mac Culloch and in Canada by Dr. Bigsby.

[309.] Body, legs and antenna fawn-colored, as are likewise the naler parts of the wings ; primaries clouded and straked with dark, and reddishbrown; the disk of these wings is occupied by a large cloud of this color inscribed with two, sometimes silvery, and sometimes golden, brilliant metallic spots, tending to form an obtuse angle with each other; the upper one, or that nearest the base of the wing being acuminated towards that part, rounded towards the apex, and sending forth two branches towards the costal area; the lower spot is subtriangular or $V$-shaped, with the point towards the base of the wings; the two together form, in some sort, a semicolon reversed; between the lower or ovate spot and the costa is a rather indistinct circlet of gold or silver, and two streaks of the same lustre may be traced lower down between it and the inner margin of the wing; the disk near the apex is bronzed; from the brown cloud mentioned above runs a wavy brown streak to the external apical angle, the apex itself is terminated by a band formed by indistinct black crescents; and above the streak is a transverse band formed by two faint lines of dark indistinct crescents including a pale band; secondary wings darker at the apex.

N. B. In the Nova Scotia specimens the discoidal spots are silvery, while in that trom Canada their lustre is golden. The synonymy of this species seems very doubtful; the metallic signature can scarcely be said to represent either a mark of interrogation, or a Greek Iota reversed; they most resemble a semicolon. 


\section{IX.-DIPTERA.}

\section{FAMILY CULICIDA.}

433. Culex PUNCTOR Kirby.-Length of body $3 \frac{1}{3}$ lines. Two specimens taken in Lat. $65^{\circ}$.

Body black. Proboscis longer than the trunk; sheath black; valvules and lancets testaceous: palpi somewhat incrassated towards the apex; antennæ broken off in both specimens; wings white, iridescent, with testaceous nervures, without scales, hairs and fringe; legs testaceous.

\section{[3IO.] FAMILY TIPULID.E.}

434. Tipula Pratorum Kirby. - Length of body 7 lines. Taken with the preceding.

§. Head and trunk slate-colored. Antennæ black, with the scape yellow; thorax with four brown stripes, the lateral ones abbreviated; wings embrowned, clouded with white; nervures black, but those at the base of the wing are testaceous; there is a black dot or two near the anterior margin; and the stigma, or what represents it, is black; the poisers are pale but black at the tip ; legs obscurely testaceous; thighs and shanks black at the tip ; tarsi black ; abdomen clubbed, yellow, with a longitudinal dorsal brown stripe; anal club black.

i. Wings not spotted with white; legs distinctly testaceous, black at the joints ; last joints of the tarsi black ; abdomen lanceolate, yellow, with a dorsal, ventral, and on each side a lateral, brown stripe.

\section{FAMILY BIBIONIDÆ.}

[31I.] 435. Aspites (ARThria) analis Kirby.-Plate vi., fig. 8.Length of body, excluding wings, 2 lines; including wings, 3 lines. Several taken in Lat. $65^{\circ}$.

Body black, naked. Head very small ; trunk with a dorsal area marked out by a ridge; on each side is a reddish-yellow line drawn from the collar to the base of the wing ; but in some specimens this is very indis- 
tinct; poisers white; wings hyaline, iridescent, much longer than the body ; costal area divided into three areolets, with testaceous nervures, terminating in a black stigma ; there are four spurious nervures, the first abbreviater, and the anal one bent towards the margin; the legs are reddish-yellow except the apex of the tarsi, which is black; the intermediate pair are sinaller and shorter than the others; anterior thighs are much incrassated, and the tibire terminate in a spine; the posterior thighs are elongated; abdomen flat above; anus jellow, as is sometimes the margin of the ventral segments.

\section{FAMILY EMPID.E.}

436. EMPIS LUCtUOSA Kirby.--length of body, including wings, 3 lines. Taken with the preceding.

Body entirely black. Proboscis very little longer than the head; wings a little embrowned, with a large black stigma, iridescent, nervures black.

[312.] 437. Fitpls gexiculata Kirly.--Length of body 3 lines. Taken with the preceding.

Very similar to the preceding, but not so black; wings slightly embrowned, beautifully iridescent; legs, where the shank is united to the thigh, white; proboscis nearly as long as the thorax.

FAMILY BOMBYLIADE.

438. BOMnyliUs major Linn.--Length of body, including proboscis, 7 lines ; excluding do., 5 lines. Expansion of wings $x$ in. to $3 / 4$ inch. Taken in Iat. $65^{\circ}$.

[3r3.] Body black, thickly covered above with yellowish, soft, but erect hairs ; underneath the hairs are whiter, but those on the breast, at the origin of the legs, are black ; wings with the anterior half longitudinally black-brown, the dark color on the inner side being sinuated or uneven; the posterior half of the wings is transparent with black nervures; the legs are long, and pale-yellow; but the tarsi are reddish-black at the extremity; the eyes are triangular.

[This species is taken in Europe, and in N. America in Nova Scotia, New York, \&c.] 
439. Bombylius pygmais Fabr.-Length of body, including proboscis, 5 lines; excluding do., 3 lines; expansion of wings 9 lines. Taken with the preceding.

Body black, hairy. Hair below the eyes black; eyes meeting at the vertex ; behind the eyes the hairs are gray; those on the thorax are tawny or reddish with a white tuft on each side at the anterior and posterior margin ; the wings are longitudinally dusky at the anterior margin; more than the posterior half is hyaline, with several scattered black dots, the interior ones being the largest; the legs are testaceous, but black at the tip ; the abdomen is covered by reddish hairs with dark ones interningled; those at the anus are whitish.

[Taken in various localities throughout N. America.]

FAMILY TABANIDF.

440. Tabanus affinis Kirby. - Length of body $73 / 4$ lines. Taken with the preceding.

[314.] Body black with hoary down. Proboscis, palpi, and base of the antennæ obscurely, all red ; down on the trunk very thin, mixed with a few black hairs ; tubercles before the wings, winglets and knob of the poisers, pale testaceous ; legs black with the four posterior tibiæ rufous ; wings emorowned, with darker nervures ; three first segments of the abdomen rufous, each with a black dorsal spot; margin of the segments pale with a whitish fringe; the fourth segment has a pair of round, red, dorsal spots.

VARIETY B. Antennæ all black.

44I. Tabanus zonalis Kirby. - Length of body $71 / 2$ lines. Taken with the preceding.

Body black, with a few hairs of the same color, especially at the sides of the trunk. Antennæ reddish at the base; sheath of the proboscis, and palpi, black ; haustellum testaceous ; breast whitish from inconspicuous down ; tubercles before the wings subferruginous ; wings subtestaceous with some of the nervures black; knob of the poisers reddish; thighs black, reddish at the tip ; tibiæ, and tarsi, except the anterior pair, which are black, as well as the apex of the anterior tibix, red; abdominal segments above and below margined with white decumbent down and fringe. 
442. Chrisups sepulchiolis Fabr.-Length of body 6 lines. Taken with the preceding.

[3 15.$]$ Body black, slightly downy. Head hoary from pubescence ; proboscis with a black sheath and testaceous haustellum; feelers black; antenna red at the base ; below the antennæ is an obtriangular levigated, and naked space, with rounded angles, and somewhat elevated; behind the antennæ in the frontal space, between the eyes, the ordinary levigated and naked areas, which in Tabanus are longitudinal, in Chrysops are transverse; sides of the trunk hairy with black erect hairs, it is also marked above with four longitudinal hoary stripes formed by invisible pubescence; underneath the trunk is covered with down of the same description and color, and set with tufts of longer hairs; wings white, with the costal margin and a middle abbreviated band, and nervures brown; legs and abdomen black, and extremity whitish from down.

[An European species.]

FAMILY SYRPHIDÆ.

443. SCÆVA RIBESII Fabr. - Length of body 4 lines. Taken with the preceding.

Head concavo-convex; underneath black, with the edge fringed with whitish hairs; rertex black; face below the antennæ yellowish; hoary from decumbent hairs next the eyes; antennæ yellowish with a darker cloud; trunk bronzed with a greenish tint, downy especially on the sides, down whitish ; wings hyaline, longer than the body, with black nervures, but those of the costal area are ferruginous; scutellum large, yellow; legs luteous, coxæ and trochanters dark-brown, posterior tarsi black, first joint below with a brush of golden colored bristles ; abdomen depressed, above black with five yellow bands, viz., one consisting of two crescents, forming an interrupted band, [3r6] traversing the middle of the first segment; then a broadish subinterrupted one traversing the base of the second and third; and lastly the margin of the two last segments is also yellow, as is the under side of the abdomen.

[An European species; taken also in Nova Scotia.]

FAMILY MUSCIDE.

444. Musca cadaverum Kirby. - Length of body $43 / 4$ lines. A single specimen taken in Lat. $65^{\circ}$. 
Body black, with black hairs and bristles. Antennæ plumate ; eyes brown; the cheeks and front in certain lights appear hoary or silvery from inconspicuous down, in others black; feelers subferruginous; trunk and abdomen black-blue with a greenish tint; wings hyaline; intermediate areolet obtusangular ; winglets white, bordered with a testaceous nervure.

This species approaches very near to $M$. cadaverina, but the front, winglets and palpi are of a different color.

445. Musca Mortisequa Kirby. - Length of body $5 \frac{1}{2}$ lines. Several taken with the preceding.

[317.] Body black, with black hairs and bristles. Eyes brown; cheek and front ferruginous, in certain lights exhibiting something of a golden lustre ; feelers long, slender, reddish-yellow ; trunk slightly hoary, with three very indistinct black dorsal stripes; wings hyaline, with the intermediate areolet projecting internally into an acute angle; winglets white terminated by a white nervure ; abdomen heart-shaped, glossy, blue with a slight tint of green.

This seems to be the American representative of $M$. vomitoria, from which it differs chiefly in having three obsolete black stripes between the wings ; in the anterior spiracles not being of a different color from the rest of the trunk; in having white winglets and not black edged with white; and in the abdomen exhibiting no changeable appearance of chequer-work.

VARIETY B. with a green abdomen.

C. with chalybeous abdomen.

X.-HOMALOPTERA, Leach.

FAMILY HIPPOBOSCIDE.

446. HIPPOBOSCA EQUINA Linn.--Length of body, excluding wings, 4 lines; including do., 5 lines. Locality not mentioned.

Body flat ; subpubescent, dirty-yellow, spotted with brown, with whitish signatures. On the forehead, between the eyes, is a brown quadrangular spot shaped like what are called skates eggs, with four projecting points 
at the angles; abdomen underneath pale, anus hairy ; tarsi with four black claws, the inner ones shorter and truncated; wings much longer than the body.

[An European species. Loew (Monographs of Diptera, part i.) divides the order of Diptera into three sections :-Nemocera, Brachycera and Coriasea, and includes this family, with the $N y c t e r i b i d a$, in the last mentioned.]

\section{[318.] XI.-APHANIPTERA.}

FAMILY PULICIDA.

447. PUieX gigas Kirby.-Plate vi., fig. 9.-Length of bot; 2 lines. Two specimens taken in Lat. $65^{\circ}$.

Body ovate, reddish-yellow; segments, particularly the first of the trunk, pectinated with black bristles ; antennæ, though short, very distinct, standing out from the head, they seem to consist of two joints, the last conical and obtuse; the base of the second segment of the trunk is black; the thighs are very flat and wide, inclining to ovate; tibiae armed with long black bristles.

This I believe is the largest flea known, but I have not been able to ascertain upon what animal it was captured. 



$$
\text { . }
$$


The foregoing reprint of Kirby's Fauna Boreali-Americana was begun in the number of the Canadian Entomologist for April, I870 (Vol. ii, No.6)), and was carried on as space could be afforded for it, and consequently with much interruption, $u_{\mathrm{p}}$ to the current year, 1876 . No one interested in the publication anticipated that so long a period of time would have elapsed before its completion. The usefulness of the reprint has no doubt been somewhat impaired by its diffusion through so many issues of our journal, and by the irregularity with which the several portions have appeared; but on the whole, it is evident that the temporary inconvenience --if such there has been to any one-has been more than counterbalanced by the criticism and consequent benefit that the work has received.

While expressing his thanks for many hints and much valuable assistan $-e$ that he has received from his friends from time to time, the compiler desires especially to state that he feels deeply grateful to Dr. George H. Horn, of Philadelphia, for the great kindness he has shown and the trouble, he has taken, in going over the whole of the Coleoptera and correcting the synonymy wherever it was not in accordance with the latest investigations of competent Entomologists. He deems himself particulaly fortunate in havin, this work done by so eminent an Entomologist as Dr. Horn, and he feels that the reprint may now go forth to the world as a satisfactory and reliable guide to the student in the determination of the species of Coleopter. described by Kirby ; without Dr. Horn's revision, it certainly would not have been so. The following is the revision of the synonymy contributed by Dr. Horn:-

SYNONYMY OF THE COJ.EOPTERA OF THE FAUNA BOREALI-AMERICANA, KIRBY.

BY GEO. H. HORN, M. D., PHILADELPHIA, PA.

Since the reprint of Kirby's Fauna Boreali-Americana began, much has been learned concerning the species of Coleoptera therein described or mentioned, so that at the present time very few remain unidentified. Through the kindness of the authorities of the British Museum, every facility was granted to Dr. Leconte and myself for the study of Kirby's types, and the results of these studies have already been made known by Dr. Leconte. It will be noticed in very many places that the synonymy here given differs very greatly from that given by Mr. Bethune, who compiled from the best known sources all that was at the time known or guessed concerning Kirby's species. 
The present paper is necessarily in great part a compilation, but sufficient new material is presented to render it worthy of appearing as a whole, so that Kirby's species may be at once determined without the necessity of consulting scattered publications.

A few words are necessary to a correct understanding of the paper. The species named by Kirby are in small capitals. Should names in their entirety remain valid, no remarks are made, as in $1,16,8 \mathrm{c}$. Should the generic name only be changed, the species is quoted as "is a_-, as in $25,28,37$, \&c. Should the specific name be changed, the species is quoted as in 3 , \&c., and the true name is in small capitals also. In some instances, Kirby's species not having been identified, the species have received more recent names and are well known; in this case the latter name (being a synonym) is quoted in italics, as in $5^{S}$ and 59 , so that those having the Kirbyan species under the more recent names may change them.

1. Cicindela hirticullis Say.

2. " repanda I)ej.

3. “ Proteus Kby. is Duodecimguttata Dej.

4. " obliquata Kby. This is a variety of the species previously described by Say under the name vulGaris. Herbst anteriorly named the species TRANQUEBARICA with a false locality.

5. " vulgaris Say (see above).

6. " " purpurea Oliv.

7. “ Albilarris Kby., is LONgilabris Say.

8. Casnonia pensylvanica Dej.

9. Cymindis marginata Kby,, is CRIBricollis Dej.

Io. " INICOLOR Kby. Subsequently described as riudsonica Lec.

11. Sericoda bembidioides Kby. is a Platynus.

I2. Brachinus cyanipennis Say.

13. Carabus Vietinghovii Adams. This species is found in Alaska and extends its habitat toward British Columbia and also toward the Hudson's Bay region. Numerous specimens were collected by the late Robt. Kennicott in Alaska.

14. " ligatus Knoch is vinctus Weber.

15. Calosoma calidum Fab.

16. " FRIGINUM Kby. 
17. Helobia [Nebria]" Castanıpes Kby. An immature form of $\mathrm{N}$. SAHLBERGI Fisch., described anteriorly to Kirby, trom Alaska.

18. Chlaenius sericeus Forst.

19. “ " impunctirrons Kby. is Pensylvanicus Say

20. " nemoralis Say.

2I. “ QUADRICOLlis Kby. is TRICOLOR Dej. var.

22. “ CORDICOLlis Kby. This species, anteriorly to Dr. Leconte's visit to the British Museum (1869), was erroneously considered to be chlorophanus Dej.

23. “ EMakginatus (Kby.) The type of this species could not be found in the British Museum. It is not identical with Say's species, and as the rame is preoccupied, it would be better to drop it entirely from our lists.

24. Platynus Axgusticolls (Kby.) is not the European species of that name, but our common Sinuatus Dej.

25. Agonum extensicolle Say is a Platynus.

26. " PICIPENNE Kby. is probably the species subsequently described as Platynus lutulentus Lec. The varieties $\mathrm{E}$ and $\mathrm{D}$ are distinct and are Plat. RUficornis Lec.

27 . " SORDENS Kby. Has been named in some collections fuscescens Chaud.

2S. " melanarium Dej. is a Platynus.

29. " seminitidum Kby. Probably the same as Platynus chaleeus I.ec.

30. " " SIMILE Kby. In doubt.

31. " affine Kby. is Platynus Harrisii Lec.

32. “ erythropum Kby. The name is pre-occupied and Plat. SUBCORDATUS Lec. must be used.

33. " cupripenne Say is a Platynus.

34. Calathus gregarius Say.

35. Platyderus vitidus Kby. is Pterost. erythropus (Dej.)

36. Argutor bicolcr Kby. is Pterost. Patruelis Dej.

37. " " "emoralis Kby. is a Pterostichus.

38. “ mandibularis Kby. is a Pterostichus.

39. " BREVICORNis Kby. Probably the same as Fastidiosus Mann. This and the preceding species belong to 
the Cryobius group of Pterostichi, in which the species are very difficult to separate.

40. Omaseus orinomum Knoch. is a Pterostichus.

4r. " NIGRITA Curtis (Kby.) This species is erroneously determined by Kirby and does not appear to differ from Pterostichus caudicalis Say, from specimens in my cabinet from Hudson's Bay region.

42. " Picicornis Kby. is Pterost. Mutus Say.

43. Stereocerus similis Kby. is Amara hakmatopus (Dej.)

44. Curtonotus convexiusculus Steph. (Kby.) Erroneously determined by Kirby ; is AMARA LATICOLLIS Lec.

45. "6 RUFImanus Kby. If the hind angles of the thorax are prominent, as stated by Dr. Leconte (Proc. Acad. I873, p. 323), this species is rather LATICOLLIS than LACUSTRIS, as there stated. The species of AMARA in this vicinity need a careful revision, when their number will be considerably decreased. No actual comparison of Kirby's and our own types have been made, and any positive expression might mislead.

46. " " BREVILABRIS Kby. Identical with the preceding species. 47. " LATIOR Kby. is AMAKa (Bradytus). Described since Kirby as libera Lec., laevistriata Putz. and Oregona Lec. (See Trans. Am. Ent. Soc., 1875, p. 128).

48. Poecilus lucublandus Say is a Pterostichus.

49. " CASTANIPES Kby. is a variety of. 48 .

50. " chalcites Say is Pterostichus Sayi Brulle.

51. Amara vulgaris Latr. (Kby.) is not that species, but erRatica

Sturm.

52. " INAEQUALIS Kby. is INTERSTITIALIS Dej.

53. " impuncticollis Say.

54. " " PALLIPES Kby.

55. " i.AEVIPENNis Kby. is a smooth ERRATICA Sturm.

56. “ Discors Kby. is Chalcea Dej.

57. Harpalus PleURiticus Kby.

58. " BASILARIS Kby. is obesuius lec.

59. " " OCHROPUS Kby. is desertus Lec.

60. " INTERPUNCTATUS Kby. is probably merely a variety of Anisodactylus nigrita Dej.

61. " LONGIOR Kby. is longicollis Lec. 


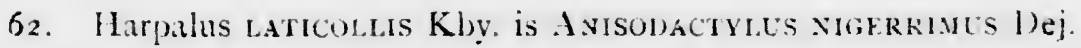

63. " carbonarius Say is AvisODAc. CARr.

$64 . \quad$ " Roturincollis Kby. is aliputates Say.

65. " " Striphisir Kby. is ampetatus Say.

66. Stcnolophus versicolor Kby. is Futigrost's Dej.

67. Trechus thalis Kby is Brabyceldts Tulatis.

68. " RLFICRLS Kby is BRADYCELLUS COGNATES (Gyll).

69. “ Havipes Kby. is Branyclilus kupestris Say.

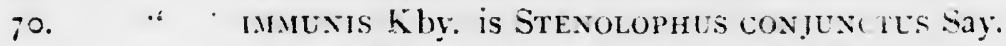

7 \% " simiris $\mathrm{K}$ by. is AroNoderus coma Fab.

72. Isopleurus Nitudes Kby. is MMara subaenea Lec.

73. Patrobus anericanus Dej. is Loxialcorvis Say.

74. Peryphus bimactiates Kby. This species of Brummose occuss also in Colorado.

75. " sorbides Kby. Immature specimen of the preceding.

76 . " scopulinus Kby: is Bearr. gelidum Lec.

77. " Ruricola Kby. is Benb. RUPESTRE Fab.

$78 . \quad . \quad$ coNcolor Kby. is Benr. salebratum Lec.

79. " PICIPES Kby. The type of this is in very bad condition. Uncertain.

So. " " " "

$3 \mathrm{I}$ " " viribus $\mathrm{Kby}$. is a Bembivium.

82. Tachyta PIcipes Kby. is Tachys xaxus Gyll.

83. Notiphus vigripes Kby. A Bembidicy which occurs also in Oregon and British Columbia.

84. “ INTERMEDIUS Kby. is probably Benibidum rapidum Ier. 85. .. VARIEGatus Kby. The specific name is pre-occupier. It is now known as BEMBID. PICTUM Lec.

86. Benbidium impressum Gyll.

87. Opisthivs Richardsonil Kby. Occurs in British Columbia, Oregon, Northern California and Colorado.

88. Elaphrus Clairvillin Kby. for a long time called politus Lec;

3) " INTERMEDIUS Kby. This species forms one of the varietie: of that known in our collections as Californici.s Mann. I cannot see any difference between this and the European RIPARIUS.

9०. $\quad \therefore \quad$ oRSCURIOR Kby. is probably a small obliteratus Mann.

91. Notiophilus aquaticus Linn. (Kby.) is semistriatus Say. 
92. Omophron Sayi Kby. is americanum Dej.

93. Haliplus impressus Latr., erroneously determined, is RUficollis De Geer.

94. Hydroporus nigrolineatus Steph. Not known to us. Is the identification correct? *

95. “ parallelus Say.

96. " LAEvis Kby. This and the preceding seem to me to be merely varieties of catascopium Say, which Crotch says is GRISEOSTRIATus De Geer.

97. " PICATUS Kiny.

98. " similis Kby. is IMPRESSOpUnctatus Schall. (fide Crotch).

99. Laccophilus biguttatus Kby. is Proximus Say.

100. Colymbetes semipunctatus Kby. is a Gauronytes.

IO1. " BICOLOR Kby. A Gavronytes.

102. “ PHAEOP'ERUS Kby. is probably GaURodytes obliteratus Lec.

103. " hifarius Kby. Placed by Crotch in a new genus, ILYBIOSOMA.

194. “ RETICUlatus Kby. is probably identical with GauroDYTES ARCTICUS Payk.

105. " " PICIPEs Kby. is an ilyeivs.

106. " assimiris Kby.

107. " " TRISERI TUS Kby. is SCULPTIIIS Harris.

I08. “ RUGicollis Kby. is GraPhODERES liberus Say.

roy. " MacCullochil Kby, is Acilius mediatus Say.

I 10. Dytiscus Ooligbuki Kby. is confluens Say.

II I. " HARRISII Kby.

I 2 . “ FRANKLINH Kby. is Confluens Say, zar.

113. Cyclinus assimilis Kby. is Dineutus americanus Linn.

114. Gyrinus Impressicollis Kby. I think the reference to Borealis Aubé is correct.

I1 5. " aeneus Leach (Kby.) Kirby's determination is probably incorrect.

I 6. " ventral.IS Kby.

* Dr. David Sharp, of Scotland, is now preparing a monograyh if the DYTISCIDAR of this world; and by means of typical apecimens from Dr, Leconte and inyself, will settle doninitely the syronymy of all of Kirby's species in this family. 

. 
1 1. Gyrinus analis Kby. Impossible to identify this species. The name is preoccupied. It is not Say's anal.IS.

I18. " minutus Fab.

119. Paederus riparius Fab. (Kby.) is LitTroRaRius Grav.

I 20. Lathrobium PUNCTICOLLE Kby.

121. “ Gravenhorsti Kby. is Cryptobiun pallipes Nord.

122. " bicolor Grav. is a CRYPTOBIUM.

123. Gyrohypnus assimilis Kby. is Xantholinus cephalus Say.

124. Olophrum marginatum $\mathrm{Kby}$. is an Omalium.

125. Alaeochara Pallitarsis Kby. is a Homalota.

I26. Tachyporus acuductus Kby. is Coproporus ventriculus Er.

127. “ AFFinis Kby.

128. Philonthus politus Linn. (Kby.) is ateneus Rossi.

129. " Mandibularis Kby. Male of aeneus.

130. " "PICATUS Kby. is BRUNNEUS Grav.

I31. " fulvipes? Grav.

132. Staphylinus Chrysurus Kby. Leistotrophus Cingulatus Grav.

133. Creophilus villosus Grav.

134. Necrophorus velutinus Fab. N. Tomentosus Weber is an older name.

135. “ HEbes Kby. is a variety of vespiLloides Herbst.

136. " " obscurus Kby. is the Melsheimeri $\ddagger$ Lec.

137. “ Melsheimeri Kby. Occurs also in Alaska and is maritima Mann.

I 38. " HaLlil Kby. is ORBICOLLis Say.

139. " PYGMAEUS Kby. is veSPILloides Hbst.

I 40. Necrodes surinamensis Fab. is Silpha SURINamensis.

141. Oiceoptoma rarginale Fab. An older name is Silpha noveboraCENSIS Voet.

142. " lapponicum Linn. is Silpha Lapponica.

143. " TRITUBERCUlatum Kby. is a SilPHA.

144. " " inaequale Fab. is SILPHa INAEQUalis.

145. " americanum Linn. has been known by the ante-Linnean name of peltata.

146. " TRRMINATUM $\mathrm{Kby}$, is a variety of the preceding.

147. " AFFINE Kby., variety of 145 .

148. " CANADENSE Kby., variety of $14^{\text {r }}$

r49. Peltis ferruginea Linn. 
150. Nitidula obscura Fab.

i5r. " ossium Khy., same as i 50.

152. “ discoidea Fab. Subsequently described as Omosita inzersa Lec., from California.

153. Ips Dejeani Kby. is vitTatus Say.

154. Choleva Spenciana Kby. is a Catops.

155. SCaphium Castanipes Kby. is very rare. Occurs also in the White Mts., N. H.

156. Leiodes punctatostriatus Kby. is Anisotoma indistinctu lec.

157. Corticaria Desticulata Khy. The name is preoccupied and was changed to Kirbyi Lec. It is probably Deletus Mann.

158. Atomaria atra Steph. (Kby.) Incorrectly determined by Kirby and is probably a dark variety of LAETUI.A i.ec.

159. Cryptophagis humeralis $\mathrm{Kby}$. is a TriphyluUs, and is ruficornis Lec.

I60. " CONCOLOR Kby. A variety of the preceding.

161. Attagenus cylindricus Kby. Belongs to a new genus, PerimkGatoma Horn. Trans. Am. Ent. Soc., 1875, p. I 35.

162. " pellio Linn.

163. Dermestes lardarius Linn.

r64. " DISSECTOR Kby. is NubiLus Say.

165. Byrrhus PICIPES Kby. Name is preoccupied and is now KiRBI Lec.

I66. " CONCOLOR Kby. Now known to us. Is not a variety of Cytilus varius Fab., but appears to be a small CYCLOPHORUS Kby.

167. " cyclophorus Kby.

168. " varius Fab. This is an erroneous determination. The species is Cytilus trivitTatus Mels.

169. Hydrobius fuscipes Linn.

r70. " marginellus Fab. Probably an erroneous determination and may be Philhydrus fimbriatus Mels.

I 7 I. “ melanocephalus $\mathrm{Ol}$. An erroneous determination and is Philyydrus perplexus Lec. I have specimens from Mr. Fettit which correspond with Kirby's description of both the above species.

172. Hister Paykuli Kby. is Depurator Say. 
173. Hister HARrisil Kby.

174. Onthophagus latebrosus Fab. is Hecate Panz.

175. “ SCabricollis Kby. is Janus Panz.

176. Trox arenarius Fab. (Kby.) This may be AEQUalis Say.

177. Peiidnota punctata Linn.

178. Camptorhina atracapilla Kby. is Serica vespertina Schonh.

179. Diplotaxis TRISTIS Kby.

180. Rhizotrogus fervens Gyll. (Kby.) is Lachnosterna fusca Fröhl.

181. " Drakir Kby. A race of 180 .

182. Dichelonycha BACKII Kby.

183. “ virescens Kby. is elongatula Schonh. Variety C is SUBVITTATA Lec.

184. “ TESTACEA Kby.

185. Cetonia fulgida Fab. is Euryomia fulg.

I86. Trichius Bigsil $\mathrm{K}$ by. is GNorimus maculosus $\mathrm{Kn}$.

187. " " ASSIMILIS Kby. is AFFinis Gory.

I88. " ROTUNDICOLlis Kby. is PICER Fab.

I89. " " viRIDANS Kby. is AFFINIS Gory.

190. Gymnodus Foveatus Kby. $\hat{\delta}$

rgr. “ Rigosus Kby. $q$ is Osmoderma scabra Beauv.

192. Platycerus piceus Weber (Kby.) is erroneously determined and is DEPRESSUS Lec.

193. Passalus interruptus Linn. (Kby.) is cornurus Fab.

194. Campylus Denticornis Kby.

195. Pedetes Brightwelli Kby. is an Athous.

196. “ (Asaphes) RUficornis Kby. is Asaphes memnonius Hbst. 197. Perimecus fulvipes Hbst. (K.by.) is Melanotus castanipes Payk. 198. " communis Gyll. is also a Melanotus.

I99. " similis Kby. A Melanotus, but the synonymy is unknown.

200. Ctenicerus Kendalli Kby. is Corymbites virens Schr.

20I. Elater AERIPENNIS Kby, is a CoRYMBITES.

202. Buprestis RUSTICORUM Kby. is a variety of MACUliventris Say.

203. " PAGANORUM Kby. is 202.

204. " NutTalli Kby.

205. " lineata Fab.

206. “ fasciata Fab.

207. " divaricata Say is a Dicerca.

208. " " TENEBROSA Kby. is a DiCERCA. 
209. Buprestis renenrica Kby. may te the same as Dicerca lugubris Lec.

210. " TRINERVIA Kby. is a CHRYSOBOTHRIS.

$2 \mathrm{II}$. " PROXIMA Kby. is ChrYSOHOThRIS SCABRIPENNIS Lap. et Gory.

$2 \mathrm{I} 2 . \quad$ " DRUMMONdi Kby. is : Melanophila.

2 13 . " umbellatarum Fab. (Kby.) is erroneously determined and is Anthaxia inornata Rand.

2 14 . " appendiculata Fab. ( $\mathrm{K}$ by.) is erroneously determined and is Meranophila longipes Say.

21 5. Agrilus bivittatus Kby. is Bilineatris Weber.

2i6. Trachys aurulenta Kby. is Brachys ovata Weber.

21 7. “ acuducta Kby. Mr. E. Saunders (Trans. Ent. Soc., Lon-

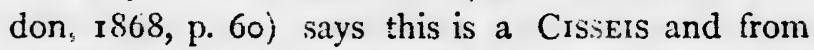
Australia.

218. Pytho NIGER Kby.

219. " AVERICANA Kby.

220. Trogosita americana Kby. is probably corticalis Mels.

22 . Monochamus Resutor Kby. is SCUtellatus Say.

222. " " CONFUSOR Kby.

223 .

" MARMORATOR Kby. is probably that variety of scuTellatus Say, called Oregonensis Lec.

224. Acanthocinus (Graphisurus) pUsillus Kby. is now called GraphiSURUS PUSILLUS Kby.

225. Callidium agreste Kby. is a Criocephalus.

226. " striatum Linn. (Kby.) is Asemum moestum Hald.

227. " COllare Kby. is now Gonocallus COllaris.

228. " " PROTEUS Kby. is nOw MERIUM PROTEUS.

229. " SIMILE Kby. is 228 .

230. " dimidiatum Kby. is : Phymatodes.

231. " ('Tetropium) CINNAM PTERUM Kby. is known as a TETROPIUN.

232. Clytus undatus Kby. is Xrlo' rechus undulatus Say.

233. " Lunulatus Kby. is the same.

234. " Fuscus Kby. A variety of the same.

235. " LONGIPES Kby. is a NeOclytus.

236. " MURICatulus Kby. is a Neoclytus and has since been described as leucizomus Lap.

237. Hargium lineatum $O I$. is a $R E$,GILM. 
238. Paclyyta imturata Kby.

239. Leptura chrysocoma Kby.

240. " SUbPUBESCENS Kby. is Proxima Say.

24I. " " ERYTHROPTERA Kby. Variety of 242.

242. " canadensis Ol.

243. “ TENuior Kby. is Typocerus velutinus Ol.

244. “ BREVIS Kby. is L. VaGaNs ()l.

245. " sexmaculata Linn.

246. " " semivittata Kby. is L. vittata Ol.

247. " GULOSa Kby. is also L. vitTata Ol.

248. " "SUbargentata Kby.

249. “ similis Kby. is rufibasis Lec.

250. " " LONGICORNis Kby. is ACMAEOPS maryinalis Lec.

251. " PROTEUS K.by. is an ACMAEors.

252. " LONGICEPS Kby. is ACMAEOPS PRATENSIS Laich.

253. Anobium foveatum $\mathrm{Kby}$ is a Hadrobregmus.

254. Cis micans Fab. (Kby.) Unknown; seems to be Chevrolari Mell.

255. Tomicus pini Say.

256. Apate bivitcata Kby. is a Xyloteres.

257. " RUfitarsis Kby. is a Xyloteres unknown to us.

258. " (Lepisomus) kufipennis Kby. is a Polygraphus.

259. “ (Lepisomus) Nigriceps Kby. Probably the same as $25^{8}$.

260. “ (Lepisomus) BREviCORnis Kby. Unknown.

261. Hylurgus RUfipennis Kby. is a Deninoctonus.

262. Calandra perinax Ol. is a SPHENOPHORUS.

263. Hylubius confusus Kby.

264. Lepyrus colon Linn.

265. " GEMELLUS Kby.

266. Cleonis vittatus Kby. is Cr.eones.

267. Macrors maculicolis Kby.

268. " vitTICOLlis $\mathrm{Kby}$.

269. LEPIJOPHORUS LINEATICULLIS Kby.

27o. Trachyphloeus melanothrix Kby. Constitutes, with a California species, a new genus, Geoderces Horn.

27 I. Pachyrhynchus SchonherRi Kby. is Ithycerus NOVeboracensis Forst.

272. Attelahus SIMILIS Kby. is ANaLIS Illig.

273. “ bipustulatus Fabr. 
274. A potumus ovatus Fab. belongs to the genus Prerocolus.

275. Anthribus fasciatus Oliv. is a Tropideres.

276. Chlamys plicata Oliv.

277. Cryptocephalus pubescens Fab. is a PaChy Brachys.

278 . $\quad \because \quad$ notatus Fab. is sellatus Suff.

279. Iimolpis vitis Fab. is correctly determined, but is an dooxus.

280. Chrysomela philadelphica Linn.

$28 \mathrm{I}$. "CoNfinis Kby. is C. spiracae Say and a variety of the preceding.

28. " " BigsByana Kóby.

$28_{3}$. " $\quad$ multipunctata Say.

284. “ cl.rvicolurs Kby. This name should remain. The

C. trimaculata Fab. is the same, but the name was pre-occupied by Linncus.

285. : rufipes De Geer is C. Pallidi Linn,, a Gonioctena.

286. Phaedon Adonidis Pallas. is an Entomoscelis.

287. " raphani Fab. Probably a correct deternination. The species is known in American cabinets as (iaSTRoPHYSA formosi Say.

283. " polygoni Linn. is a Gastrophysa.

289. Phyllodecta vitellinae Linn.

290. Haltica vicina Kby. appears to be Disonycha alternata Illig.

29I. " PUNCTicolis Kby. is Disonicha triangularis Say.

292. Galeruca Olivieri Kby. is Phyllobrotica decorata Say.

293. " CANadensis Kby. A Trirhabdi, and Crotch thinks it a variety of TOMENTOSA Linn.

294. " sagittaria Gyll. This species and its allies form the genus Galerucella Crotch.

295. “ BILINEATA Kby. is a variety of Galerucella Notclata Fab.

296. “ MARginelia Kby. is a GalerUChlia.

297. Orsodacna tibialis Kby:

298. “ ChILdReni Kby. These two are considered identical, and the latter name adopt_d.

299. Haemonia Nigricornis Kby. This seems to be the same as that subsequently described by Lacordaire as Meishcimeri. I have seen Canadian specimens which do not differ.

300. Donacia feMoralis Kby. 
301. Donacia flavipes Kby.

302. " " aFFinis Kby. is KiRnYi Lac.

303. " " EMARGINATA Kby.

304. " " PROXINA Klby.

305. " " CUPRAA Kby.

306. " " HIRTICOLLIS Kby.

307. "

308. Hispa bicolor Oliv. is an Onontota.

309. Coccinella eriscopalis $\mathrm{Kby}$. is an Avisosticta.

3 10. " "tredecimpunctata Linn. is a Hippodamia.

$3 \mathrm{I}$. " " TRIDENS Kby. is HipPOdamia PARENTHesis Say.

312. " " QUiNQUESIGNATa Kby, is a Hippodamia.

313. " Quinguenotata Kby. In the revision of the Coccinellidæ Trans. Am. Ent. Soc., 1873, p. 370, Crotch allows the name to remain. In his general revision (published posthumously) London, 1874 , the name is placed as a synonym of TRANSVERSOGUTTA'TA, which is probably correct.

314. " TRICUSPIS Kby. In the London publication the name by Kirby is said to be pre-occupied and changed to KIRPYI by Crotch, but is allowed to remain in the American publication.

35. “ incarnata. Kby. is Anisocalvia buodecimmaculata Gelbl.

3i6. Pimelia ai.ternata Kby. is Eleodes tricostata Say.

- 317. Upis ceramboides Lini.

318. Tenebrio molitor Linn.

319. “ pensylvanicus $\mathrm{Kn}$. is a Nycrobates.

320. Diaperis bicornis $\mathrm{Ol}$. is a Hoplocephala.

32. Bolitophagus cornutus Fab. is Bolitotherus nifurcus Fab.

322. " obcordatus Kby. is a Phellopsis.

323. Meracantha canadensis Kby. is contracta Beauv.

324. Arthromacra donacioides Kby. is Aenfa Say.

325. Cistela erythropa Kby. is Annrochirus luteiper Lec., which ir not rare in Canada.

326. Xylita buprestoides Payk. X. Laevigata Hellen. is an older name.

327. Notoxus monodon Fab.

328. Cantharis unicolor Kby. is a Macrobasis, cinerea $\|$ rab. and Fabricii Lec. are its synonyms. 
329. Meloe Impressa Kby.

330. " NIGRA Kby.

331. Dasytes fovercollis $\mathrm{Kby}$. is a Dolichosoma.

332. Necrobia violacea Linn. is a CORYNETES.

333. Thanasimus ABDOMinalis Kby. is nubilus Klug, a variety of UNDULATUS Say.

334. Cyphon fusciceps Kby.

335. Telephorus ater Linn. (Kby.) is erroneously determined and is FRAXINI Say.

336. " Westwounn Kby. The legs of this species are dark.

It seems to me merely a variety of the next.

337. “ SamouelliI Kby.

338. " CURTisi Kby. This and the preceding are the same.

339. " "

340. " " LAE.icollis Kby. is a PODABRUS.

341. " " MANDIBUlaris Kby. does not differ from FRaxini Say.

342. “ Bennetil Kby. is Podabrus tricostatus Say.

343. Lampyris corrusca Linn. is an Ellyckinia.

Synopsis of Kirby's Species.

Number of species described as new by Kirby ............... ${ }_{23} 8$

Those which retain Kirby's specific names and are known to us..... I I I

Number which must be considered synonynus $\ldots \ldots \ldots \ldots \ldots \ldots$ o 8

Specific names pre-occupied and a more recent name used ........ 6

Species in doubt and undetermined by us.............. I0

To be dropped (name pre-occupied and type lost in one instance). .. 2

Two species mixed under one name..$\ldots \ldots \ldots \ldots \ldots \ldots \ldots \ldots$ 2

Number of species quoted from previous authors.............. 105

Of these there are correctly determined $\ldots \ldots \ldots \ldots \ldots \ldots \ldots . \ldots 8$

Those which must be placed in synonymy on account of incorrect

determination or otherwise ............... 35

Uncertain and unknown to us................... 2

Australian species described in error. . . . . . . . . . . . . . 
